\title{
CAMILA OLIVEIRA DO PRADO
}

\section{Padronização de uma Reação em Cadeia pela Polimerase (PCR) para detecção do herpesvírus equino tipo 1 em tecidos incluídos em parafina}

São Paulo 


\section{CAMILA OLIVEIRA DO PRADO}

\section{Padronização de uma Reação em Cadeia pela Polimerase (PCR) para detecção do herpesvírus equino tipo 1 em tecidos incluídos em parafina}

Dissertação apresentada ao Programa de Pós-Graduação em Epidemiologia Experimental Aplicada às Zoonoses da Faculdade de Medicina Veterinária e Zootecnia da Universidade de São Paulo para obtenção do título de Mestre em Ciências

Departamento:

Medicina Veterinária Preventiva e Saúde Animal

Área de concentração:

Epidemiologia Experimental Aplicada às Zoonoses

Orientador:

Prof. Dr. Leonardo José Richtzenhain 
Autorizo a reprodução parcial ou total desta obra, para fins acadêmicos, desde que citada a fonte.

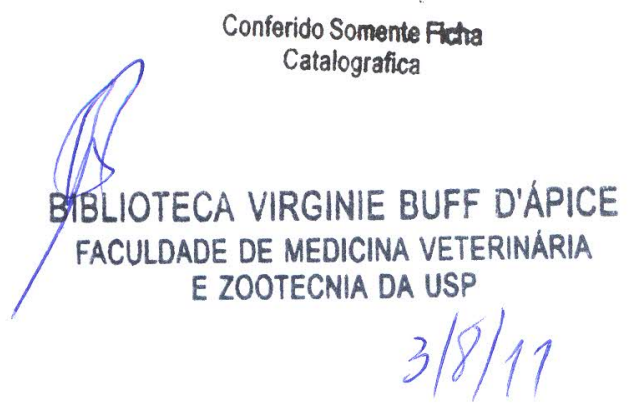

DADOS INTERNACIONAIS DE CATALOGAÇÃO-NA-PUBLICAÇÃO

(Biblioteca Virginie Buff D’Ápice da Faculdade de Medicina Veterinária e Zootecnia da Universidade de São Paulo)

\begin{tabular}{|c|c|}
\hline \multirow[t]{5}{*}{$\begin{array}{l}\text { T. } 2485 \\
\text { FMVZ }\end{array}$} & $\begin{array}{l}\text { Prado, Camila Oliveira do } \\
\text { Padronizaçăo de uma Reaçăo em Cadeia pela Polimerase (PCR) para deteçăo do } \\
\text { herpesvírus equino tipo } 1 \text { em tecidos inclú́dos em parafina / Camila Oliveira do Prado. } \\
\text { - 2011. } \\
\text { 107 f. : il. }\end{array}$ \\
\hline & $\begin{array}{l}\text { Dissertaçăo (Mestrado) - Universidade de Săo Paulo. Faculdade de Medicina } \\
\text { Veterinária e Zootecnia. Departamento de Medicina Veterinária Preventiva e Saúde } \\
\text { Animal, Såo Paulo, 2011. }\end{array}$ \\
\hline & $\begin{array}{l}\text { Programa de Pós-Graduaçăo: Epidemiologia Experimental Aplicada às Zoonoses. } \\
\text { Área de concentraçăo: Epidemiologia Experimental Aplicada às Zoonoses. }\end{array}$ \\
\hline & Orientador: Prof. Dr. Leonardo José Richtzenhain. \\
\hline & $\begin{array}{l}\text { 1. Herpesvirus equino tipo }-1 \text { (EHV-1). 2. Infecçăo experimental. 3. PCR em } \\
\text { amostras cllnicas incluidas em parafina. I. T(tulo. }\end{array}$ \\
\hline
\end{tabular}


Comissão de Ética no uso de animais

\section{CERTIFICADO}

Certificamos que o Projeto intitulado "Padronização de uma rełção em cadeia pela Polimerase (PCR) para deteção do Herpes Virus Equino tipo 1 em tecidos incluidos em parafina de camundongos experimentalmente infectados", protocolado sob o n" 1949/2010, utilizando 30 (trinta) camundongos e um número indeterminado de cavalos, sob a responsabilidade do Prof. Dr. Leonardo José Richtzenhain, está de acordo com os princípios éticos de experimentação animal da "Comissão de Ética no uso de animais" da Faculdade de Medicina Veterinária e Zootecnia da Universidade de São Paulo e foi aprovado em reunião de $11 / 08 / 2010$.

We certify that the Research "Standardization of a Polymerase Chain Reaction (PCR) for Equine Herpesvirus type 1 detection in paraffin embedced tissues from experimentally infected mice", protocol number 1949/2010, under the responsibility Prof. Dr. Leonardo José Richtzenhain, agree with Eihical Principles in Animal Research adopted by "Ethic Committee in the use of animals" of the School of Veterinary Medicine and Animal Science of University of São Paulo and was approved in the meeting of day 08/11/2010.

São Paulo, 12 de agosto de 2010

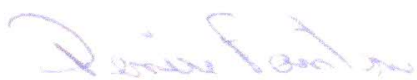

Profa. Dra. Denise Tabacchi Fantoni

Presidente 


\section{FOLHA DE AVALIAÇÃO}

Nome: PRADO, Camila Oliveira do

Título: Padronização de uma Reação em Cadeia pela Polimerase (PCR) para detecção do herpesvírus equino tipo 1 em tecidos incluídos em parafina

Dissertação apresentada ao Programa de PósGraduação em Epidemiologia Experimental Aplicada às Zoonoses da Faculdade de Medicina Veterinária e Zootecnia da Universidade de São Paulo para obtenção do título de Mestre em Ciências

Data:

\section{Banca Examinadora}

Prof. Dr. Instituição:

Assinatura: Julgamento:

Prof. Dr. Instituição:

Assinatura: Julgamento:

Prof. Dr. Instituição:

Assinatura: Julgamento: 
A Dens. 
Dedico este trabalho aos meus pais cleuza e paulo, pelo incentivo e pela compreensão durante os momentos dificeis. Pelo carinho, amore cumplicidade durante a minha caminhada pessoal e profissional.

Ao meu tio orlando, que não está mais presente fisicamente, mas sempre foi minha inspiração profissional.

Aos camundongos da experimentação, que cederam suas vidas para esta pesquisa. 
Deus, agradeço por me guías durante a caminhada terrestre, por nunca me abandonar e sempre me mostrar o melhor caminho.

Aos meus pais, cleuza e paulo, que com amor, sabedoría e muito carinho sempre me apoiaram na minha decisão profissional. Abrigada por confiarem em mim.

A minha familía (tios, primos, avós), que se alegra com minha alegria e que me amparam nas etapas de dificuldade. Agradeço os conselhos eincentivos.

A todos que contribuíram para a conclusão deste trabalho direta on indiretamente, e de maneira especial:

Ao meu orientador, Prof. Dr. Leonardo José Richtzenhain, pela confiança depositada em mim, pelos ensinamentos, paciência e orientação.

A pesquisadora Dra. Claudia Del Fava, do Laboratório de Anatomía Patológica, instítuto Biologico, Agêncía Paulista de Tecnología do Agronegócio - APTA da secretaría de Agricultura e Abastecimento do Estado de são Paulo, por disponibílizar o laboratório para o processamento de partes das amostras utilizadas neste trabalho. Pelo carinho e dedicação na transmissão dos conhecimentos de patología. obrigada Dra. Claudia por fazer parte da minha história cientifica.

As pesquisadoras Dra. María do carmo custódio de Souza Hunold Lara, Dra. Eliana Monteforte cassaro Villalobos e a Dra. Elenice María Sequetin cunha do laboratório de Raiva e Encefalites virais, instituto Biologico, Agêncía Paulista de Tecnología do Agronegócio - APTA da Secretaría de Agricultura e Abastecimento do Estado de São Paulo, por disponibilizarem o isolado viral, permitindo a realização deste trabalho.

A Dra cecilía M Galosi Profesora adjunta de la cátedra de Virología de la facultad de ciencias veterinarias de la UNLP e investigadora independiente de la comisión de investigaciones científicas de la pcía de BS. As. Obrigada por disponibilizar os isolados argentinos, permitindo a realização deste trabalho.

A Dra. Alessandra Marnie Martins Gomes de castro, por ser tutora, amiga, conselheira e companheira em todos os momentos, pelo 
conhecimento teórico e pratico transmitidos com carinho e segurança. obrigada por fazer parte da minha históría cientifica.

Ao Dr. Enio Mori, pelos conhecimentos transmitidos durante esses anos e pelo carinho que dispensou para execução deste trabalho. obrigada por estar presente no inicio da minha jornada científica.

Aos grandes amigos Antonio, carolina, cintia Favero, cintia Baldin, Elizabeth, Francismar, Giselle, Haila, Iracema, Juliana, Katarina, Marcos, Sueli, Aline Pontes, Amália, Ana, Bruna, Danilo, Karen Ferrari, María, Francisco, Andréla, Ana, Paloma, Vasco, Sibeli, Leonardo, Nadia, Nelson, Tíago, Ariana, Cintia Mori, Sergio, Ricardo, ...... por estarem sempre presentes. Obrigada pela paciência, carinho e amizade.

A técnica e amiga sheila de oliveira silva santos, pelo carinho com que sanaram todas as minhas duvidas nesses anos.

A Aline Diniz cabral uma companheira inestimável. Pela ajuda prestada no termino deste trabalho.

Aos inesquecíveis Jeovania, Michele, Bruno Leonardo, Maria Eugênía, Raissa e Yolanda, equipe do Laboratório de Anatomía Patológíca do instítuto Biológico - são Paulo, pela ajuda no processamento das amostras, pelo carinho e amizade sincera.

Aos técnicos, sandra, Alexandre, Renato, Jucelía e Gisele, pela amizade e companhéirismo.

Aos professores, funcionários e colegas do Departamento de Medicina Veterináría Preventiva e saúde Animal da Faculdade de Medicina veterináría e Zootecnía da universidade de São Paulo, pelo carínho desses dias de convivêncía.

À secretaría do Departamento de Medicina Veterináría Preventiva e saúde Animal pelo apoio durante esse período.

À secretaría de pós-graduação da Faculdade de Medicina Veterináría e Zootecnía da universidade de são Paulo pelo apoío durante esse período.

À Coordenadoría de Aperféiçoamento de Pessoal de Nível Superior CAPES pela concessão da bolsa de mestrado. 
À equipe da Biblioteca da Faculdade de Medicina veterinaria e Zootecnía da universidade se são Paulo, pelo carinho que dispensarão na revisão e formatação final da dissertação

Ao Ricardo, uma pessoal muito especial, que com paciência me ajudou na formatação e revisão ortográfica desta dissertação. Muito obrigada por estar ao meu lado nesse momento e por todos os outros que ainda virão. 


\section{RESUMO}

Prado, C. P. Padronização de uma Reação em Cadeia pela Polimerase (PCR) para detecção do Herpesvírus Equino tipo 1 em tecidos incluídos em parafina. [Standardization of a Polymerase Chain Reaction (PCR) for Equine Herpesvirus type 1 detection in Paraffin-Embeded Tissues.] 2011. $107 \mathrm{f}$. Dissertação (mestrado em Medicina Veteronária) - Faculdade de Medicina Veterinária e Zootecnia, Universidade de São Paulo, São Paulo, 2011.

O Herpesvírus equino tipo -1 (EHV-1) pertence ao gênero Varicellovírus da subfamília Alphaherpesvirinae pertencente à Família Herpesviridae. É um vírus envelopado, de DNA linear fita dupla, composto por 76 genes distintos. O EHV-1 é responsável por grandes prejuízos econômicos na equinocultura mundial. Responsável por doença neonatal fatal, mieloencefalopatia, rinopneumonite e abortamento, encontra-se amplamente distribuído pela população equina do território nacional. O objetivo do presente estudo foi o de padronizar uma reação em cadeia pela polimerase (PCR) para detecção do EHV-1 em tecidos incluídos em parafina a fim de permitir estudos retrospectivos em arquivos de amostras histopatológicas. Assim, foram inoculados experimentalmente 12 camundongos com 21 dias de idade da linhagem $\mathrm{CH} 3 /$ Rockfeller com três diferentes isolados de EHV-1, dois provenientes da Argentina e um do Brasil. Esses animais foram observados por quatro dias e, após sacrifício por sobre dose de uma associação de ketamina e xilazina, foram submetidos à necropsia e colhidos o pulmão e sistema nervoso central (SNC). Os órgãos colhidos foram divididos em duas partes aproximadamente iguais: uma mantida a $-20^{\circ} \mathrm{C}$ até processamento e a outra fixada em formalina $10 \%$ tamponada e posteriormente incluída em parafina. A extração foi 
realizada com nove fragmentos contínuos de $4 \mu \mathrm{m}$ cada, a partir do protocolo de extração com proteinase $\mathrm{K} /$ fenol/ clorofórmio. Foi realizada avaliação da sensibilidade analítica da PCR com oito diluições na base 10 para os três isolados utilizados. A amplificação do DNA viral foi realizada utilizando primers direcionados para a ORF64. A fim de descartar a eventual presença de inibidores da reação de PCR e assegurar a adequada extração de DNA, foram incluídos primers direcionados para o gene da beta-actina. A PCR mostrou-se capaz de amplificar DNA viral alvo numa diluição de até $10^{-5}$, sendo positiva entre $10^{-1}$ a $10^{-2}$ DICT50/25 $\mu$ L. Com a PCR padronizada, foi possível detectar o DNA do EHV-1 em: a) $100 \%(12 / 12)$ das amostras de pulmão congeladas e $100 \%(12 / 12)$ das amostras de pulmão incluídas em parafina; b) em 91\% (11/12) das amostras de SNC congeladas e 41\% (5/12) das amostras de SNC incluídas em parafina. A aplicação da PCR padronizada em uma coleção de amostras incluídas em parafina do Laboratório de Anatomia Patológica do IB/SP, colhidas de cinco casos de abortamento em equinos, revelou que o DNA do EHV-1 foi detectado em: a) um caso em que originalmente foi possível isolar o EHV-1; b) em 4/4 amostras que revelaram-se originalmente negativas. Com base nos resultados obtidos, foi possível concluir que a PCR padronizada teve bom desempenho na detecção de DNA viral em amostras incluídas em parafina de animais experimentalmente infectados e, provavelmente, uma sensibilidade diagnóstica mais elevada que os métodos utilizados para o diagnóstico do EHV-1 na coleção de amostras de equino testada.

Palavras-chave: Herpesvírus equino tipo-1 (EHV-1); infecção experimental em camundongos; PCR em amostras clínicas incluídas em parafina. 


\section{ABSTRACT}

Prado, C. O. Standardization of a Polymerase Chain Reaction (PCR) for Equine Herpesvirus type 1 detection in Paraffin-Embeded Tissues. [Padronização de uma Reação em Cadeia pela Polimerase (PCR) para detecção do Herpesvírus Equino tipo $1 \mathrm{em}$ tecidos incluídos em parafina]. 2011. $107 \mathrm{f}$. Dissertação (mestrado em Medicina Veterinária) - Faculdade de Medicina Veterinária e Zootecnia, Universidade de São Paulo, São Paulo, 2011.

The equine herpesvirus type 1 (EHV-1) belongs to Varicellovírus genus, Alphaherpesvirinae subfamily of the Herpesviridae Familly. It is an enveloped virus, double stranded linear DNA, composed of 76 distinct genes. The EHV-1 is responsible for great losses in horsebread world. Responsible for neonatal death, mieloencephalopaty, rinopneumonite and abortion, it is widely distributed into brasilian equine population. The purpose of this study was to standardize a polymerase chain reaction (PCR) for EHV-1detection in paraffin- embedded tissues allowing retrospective studies based on the collection histopatological samples. Thus, 12 mice ( $\mathrm{CH} 3 /$ Rockfeller) with 21 days of age were inoculated with 3 different isolates of EHV-1, 2 from Argentina and one from Brazil. These mice were observed for 4 days and, after sacrifice by overdose of a combination of ketamine and xylazina, it were subjected to necropsy and collected the lung and central nervous system (SNC). The collected tissues were divided into 2 approximately equal parts: 1one stored at $-20^{\circ} \mathrm{C}$ until processing, and another set at $10 \%$ buffering formalin and later paraffin-embedded. The extraction was performed with continuous 9 fragments of $4 \mu \mathrm{m}$ each, using the extration protocol with proteinase $\mathrm{K} /$ fenol/ clorofórmio. The assessment of analytical sensitivity of PCR were determined using 8 dilutions for all 
3 virus isolates. The viral DNA amplification was performed using primers targeted to ORF64. In order to rule out the possible presence of PCR inhibitors and to ensure adequate extraction of DNA, primers directed to the gene for beta-actin were included It was possible to amplify viral DNA until $10^{-5}$ dilution, corresponding to $10^{-1}$ to $10^{-2}$ DICT50/25 $\mu \mathrm{L}$. With the standardized PCR, it was possible to detect the EHV1 DNA in: a) $100 \%$ (12/12) of lung frozen sample and $100 \%(12 / 12)$ of the paraffinembedded lung; b) $91 \%(11 / 12)$ of the frozen CNS and $41 \%(5 / 12)$ CNS paraffinembedded. Moreover, the standardized PCR was tested in a collection of paraffinembedded specimens from Pathological Anatomy Laboratory od Biological Institute - Sao Paulo State, taken 5 cases of the abortion in horses. It were possible to detect EHV-1 DNA in: a) 1 sample from a case in that originally was possible to isolate the EHV-1, b) $4 / 4$ sample originally negative diagnosed. Based on these results, it is possible to conclude that the standardized PCR performed well for detection viral DNA in paraffin-embedded tissues of experimentally infected animals, and probably a higher diagnostic sensitivity than the methods used for diagnosis of EHV-1 in the collection samples tissues tested for equine.

Keywords: Equine herpesvírus; experimental infection in mice; PCR in clinical paraffin-embedded tissue. 


\section{LISTA DE FIGURAS}

Figura 1- Desenho esquemática de um vírion da família Herpesviridae. A figura mostra o envelope glicoprotéico, capsídeo viral e o DNA linear no interior do vírion. (fonte: www.expasy.org, acessado em: 27/06/2011).

Figura 2- $\quad$ Organização esquemática do genoma do EHV-1. Observe as regiões, única longa "UL" e a região única curta "US". As seqüências repetidas interna IRS e a terminal TRS estão destacadas em preto (retirado de: SÁENZ,J.R.; URCUQUIINCHIMA, S. 2006)

Figura 3- Localização e função dos 76 genes distintos do EHV-1 e EHV-4. Destaque para ORF64 do EHV-1 (fonte: ALLEN, 2002; www.ivis.org)......

Figura 4- Ciclo esquemático da transmissão do EHV-1. O ciclo consiste na transmissão entre eqüídeos através do contato oronasal. Quanto a égua se infecta com EHV-1 antes ou durante a prenhez, pode ocorrer aborto (fonte: homepage.usask.ca)

Figura 5- Diluição esquemática na base 10 dos três isolados dos EHV-1 usados para inoculação experimental. Os isolados do EHV-1 foram diluídos em TE $(10 \mathrm{mM}$ Tris-HCL, $1 \mathrm{mM}$ de EDTA) e diluídos em macerado de pulmão a $20 \%$. A diluição foi feita acrescendo $25 \mu \mathrm{L}$ do vírus ao primeiro microtubo do diluente $(225 \mu \mathrm{L})$. Depois de homogeinizado foi transferido do primeiro microtubo para o segundo $25 \mu \mathrm{L}$ prosseguindo dessa maneira até completar as 8 diluições do vírus $\left(\left(10^{-1}\right.\right.$ a $\left.10^{-8}\right)$

Figura 6- Géis dos produtos amplificados pela nested- PCR das diluições virais. Considerando-se positivos os fragmentos de aproximadamente $263 \mathrm{pb}$. (A) AR N1 (ARG1) positivo até a 5 diluição, (B) AR N2 e (C) A3/97 positivos até a $4 \stackrel{\circ}{\circ}$ diluição, "C+": controle positivo, "C-": controle negativo.

Figura 7- llustração da positividade dos órgãos congelados dos camundongos inoculados com EHV-1. (A) camundongo inoculado com o isolado AR N1; (B) camundongo inoculado com 0 isolado inóculo AR N2. (C) camundongo inoculado com A3/97. Considerando positivos os fragmentos com tamanho de 263pb. "P": pulmão, "SNC": sistema nervoso central, "C-": controle negativo, "C+": controle positivo; "A": controle negativo da nested-PCR, "LA": padrão de pares de base (lader).

Figura 8- $\quad$ llustração da positividade dos órgãos incluidos em parafina dos camundongos inoculados com EHV-1. (A) camundongos inoculados com o isolado AR N1; (B) camundongo inoculado com o isolado A3/97; (C) camundongo inoculado com o isolado AR N2. Considerando positivos fragmentos de 263pb. "P": pulmão, "SNC": sistema nervoso central, "C-": controle negativo, "C+": controle positivo; "MIX": controle negativo da PCR, "A": controle negativo da nestedPCR, "LA":padrão de pares de base (lader). 
Figura 9- $\quad$ Foto ilustrativa das amostras positivas para o gene da beta-actina dos órgãos incluídos em parafina dos camundongos do grupo de inoculados com AR N2 e A3/97, considerando positivas as amostras com fragmento com aproximadamente de $567 \mathrm{pb}$. As colunas 1-2 são pulmão e SNC do camundongo controle inoculados com AR N2, colunas 3- 4 pulmão e SNC do camundongo controle inoculado com A3/97, coluna 5 pulmão do camundongo 1 inoculado com $A 3 / 97$ e coluna 6 controle negativo

Figura 10- llustração do pulmão (A) e do SNC (B) mostrando morfologia normal dos órgãos (Aumento de 100x).

Figura 11- llustração da lesão pulmonar classificada como infiltrado inflamatório mononuclear focal com congestão (A) (Aumento de 40x)

Figura 12- llustração da lesão pulmonar classificada como infiltrado inflamatório mononuclear intersticial moderado difuso (Aumento de 100x).

Figura 13- llustração da lesão pulmonar classificada como o infiltrado inflamatório mononuclear intersticial severo e difuso (A) com congestão alveolar (B) (Aumento de 40x).

Figura 14- llustração da lesão pulmonar classificada como infiltrado inflamatório mononuclear intersticial moderado $(A)$ e neutrofilos no lumém dos bronquíolos (B) (Aumento de 400x).

Figura 15- Ilustração do SNC destacando o foco de infiltrado inflamatório mononuclear (A) e manguito perivascular mononuclear (B) no neurópilo (Aumento de 100x). em (C) manguito perivascular mononuclear no neurópilo (aumento de 400x)

Figura 16- Gel ilustrativo dos fragmentos amplificados das amostras clínicas testadas para a presença de EHV-1. (A): linhas 1 e 2 amostras de 2007 e 2008, 3 controle negativo; $\mathrm{C}+$ controle positivo; (B): linhas 4 controle negativo, 5 e 6 amostras de 2010, C+ controle positivo. 


\section{LISTA DE QUADROS}

Quadro 1- Detalhes do rebanho equídeo brasileiro por região. Número efetivo de animais dos rebanhos de asininos, eqüinos e muares.

Quadro 2- $\quad$ Principais herpesvírus de importância veterinária 33

Quadro 3- $\quad$ Algumas das vacinas utilizadas no Brasil para controle do EHV-1 e EHV-1.....

Quadro 4- $\quad$ Separação dos três grupos de camundongos que foram inoculados com os isolados de EHV-1 argentinos e brasileiro. Os animais de 1-4 são os camundongos inoculados com os isolados do EHV-1, C- camundongo usado como controle negativo da inoculação.

Quadro 5- Detalhamento dos órgãos dos camundongos que foram parafinados e/ou mantidos a $-20^{\circ} \mathrm{C}$ até a extração. P: órgãos formalizados e incluídos em parafina; C: órgãos congelados; 1-4: camundongos de 21 dias inoculados com os três diferentes isolados de EHV-1; C-: camundongo de 21 dias utilizado como controle negativo da inoculação.

Quadro 6- Primers codificadores da ORF 64, para identificação de EHV-1 64

Quadro 7- Descrição do ciclo de amplificação do DNA da ORF64 do EHV-1 com as etapas.

Quadro 8- $\quad$ Primer codificador do gene da $\beta$-actina de camundongos usado como controle da PCR. * ref/NT039718.7/ camndongo musmuscullus strain C57B2/6J; cromossomo X; contig MGSCv37.

Quadro 9- Programa de amplificação do DNA viral, etapas, temperaturas e tempo correspondente a PCR.

Quadro 10- Protocolo de desidratação, diafanização e embebição em parafina dos fragmentos de órgãos fixados em formol 10\% tamponado

Quadro 11- Detalhamento da positividade na sensibilidade analítica com os primers direcionados para ORF64 do EHV-1. O isolamento AR N1 foi positivo até a $5^{\circ}$ diluição; os isolados AR N2 e A3/97 foram positivos até a 4 diluição.

Quadro 12- Reusltado detalhado dos órgãos dos camundongos inoculados, congelados e incluídos em parafina, positivos para pesquisa do EHV-1 e para $\beta$ - actina.

Quadro 13- Amostras clínicas utilizadas para comprovar a aplicabilidade da PCR padronizada para extração de EHV-1 de órgãos incluídos em parafina. 


\section{LISTA DE ABREVIATURAS E SIMBOLOS}

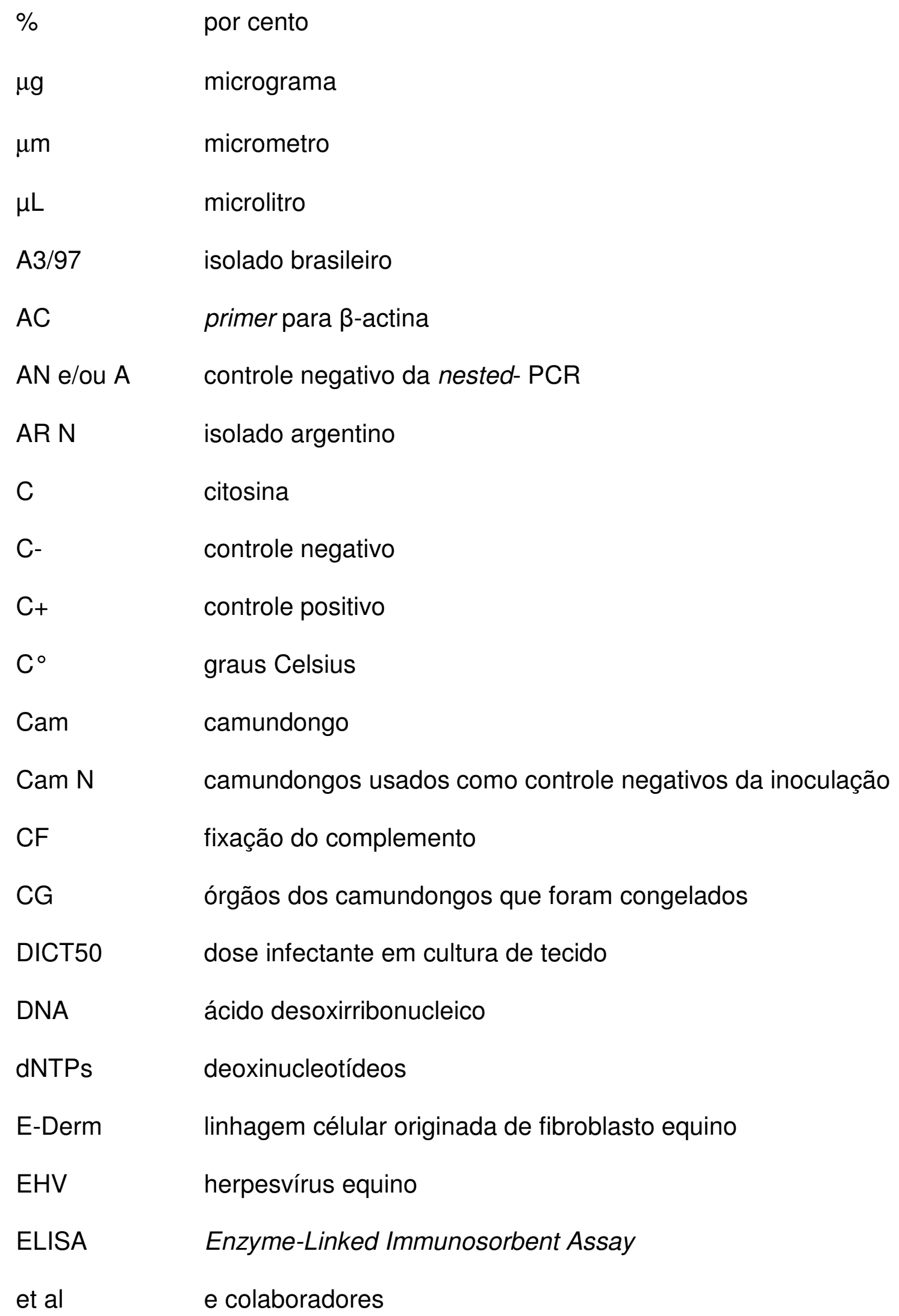




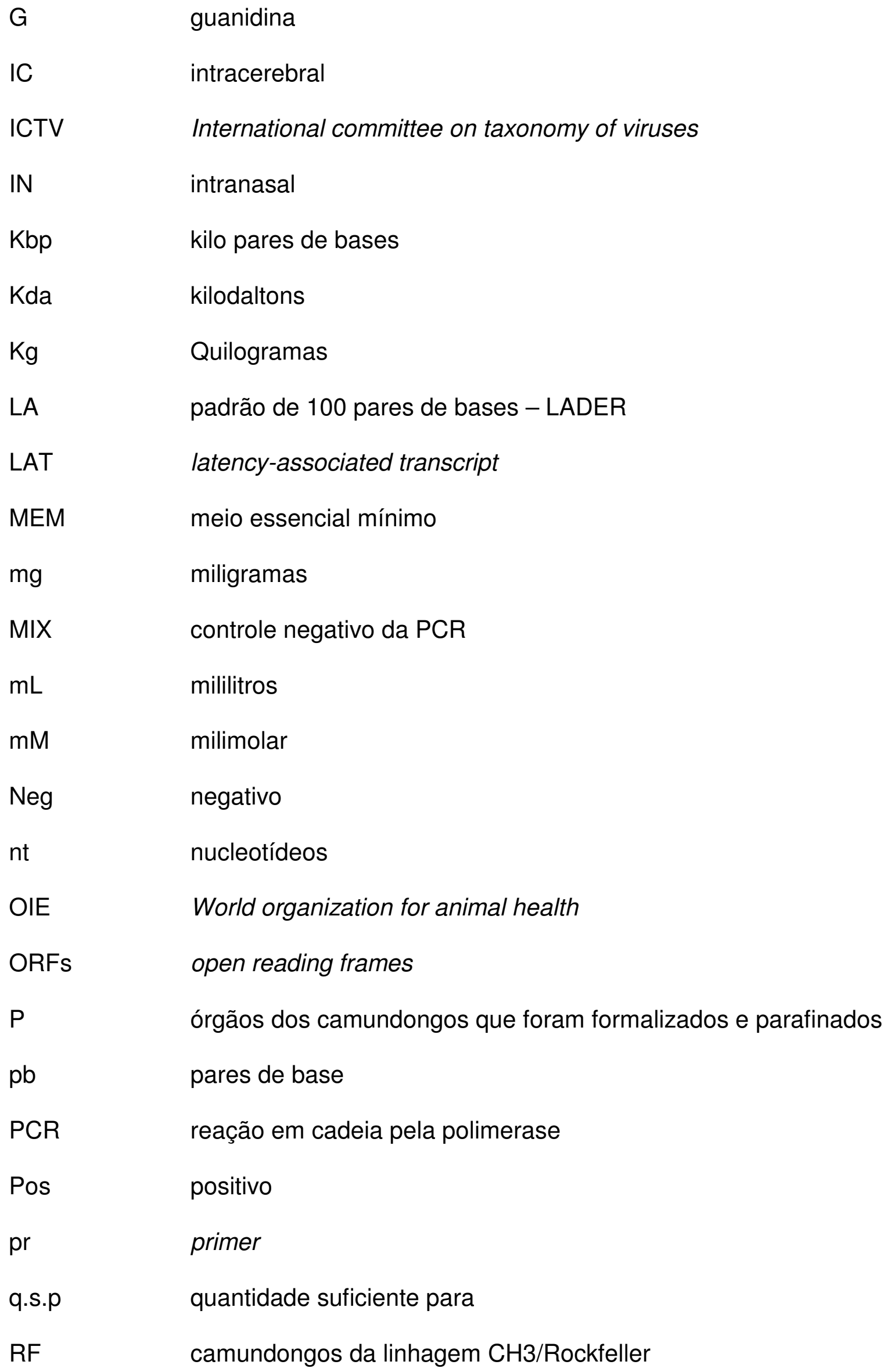


RK-13 linhagem célular originada de rim de coelho

rpm rotações por minutos

SNC sistema nervosa central

US\$ dólares americanos

V/cm Volt por centímetro 


\section{SUMÁRIO}

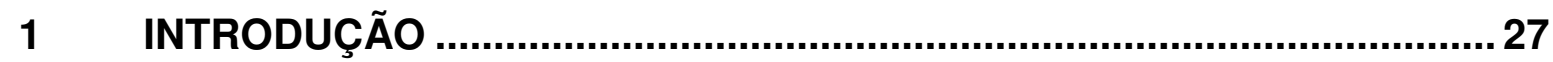

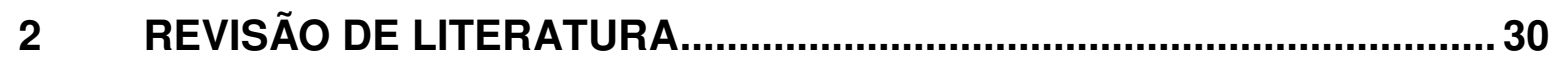

2.1 HISTÓRICO

2.2 CLASSIFICAÇÃO VIRAL E ESTRUTURA GENÔMICA ….........................33

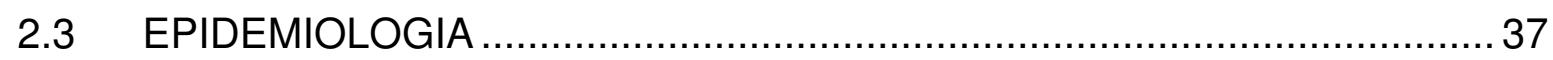

2.4 MODELO ANIMAL PARA EXPERIMENTAÇÃO....................................... 43

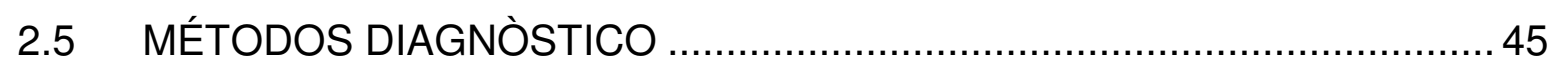

2.5.1 Métodos indiretos de diagnòstico …………........................................ 46

2.5.2 Métodos diretos de diagnòstico ………….......................................... 47

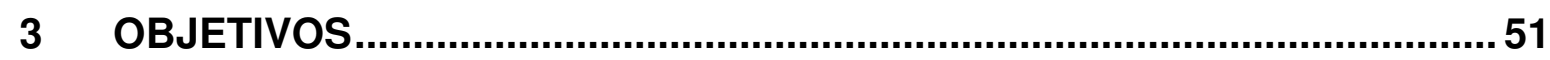

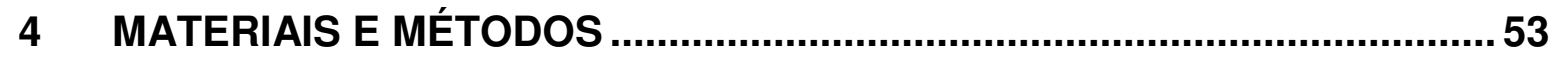

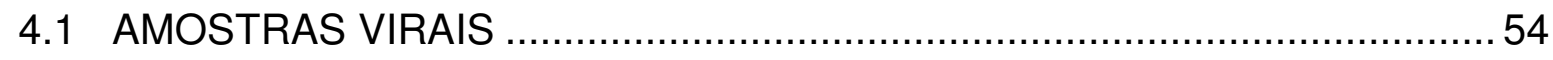

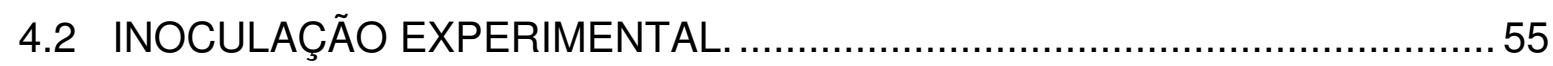

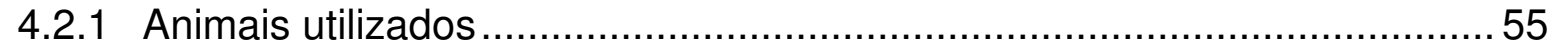

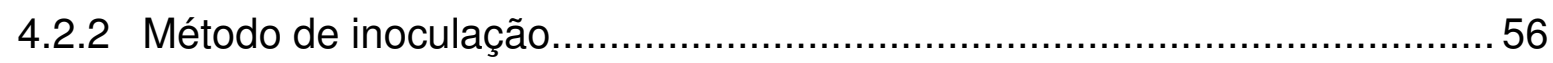

4.3 PADRONIZAÇÃO DA REAÇÃO EM CADEIA PELA POLIMERASE ..........59

4.3.1 Avaliação da sensibilidade analítica da PCR ..........................................59

4.3.2 Controles da extração e amplificação ...................................................... 61

4.3.3 Extração do DNA de material congelado .................................................... 61

4.3.4 Extração do DNA de material incluído em parafina ..................................... 62

4.3.5 Oligonucleotídeos iniciadores (primers) EHV-1 ...................................... 64

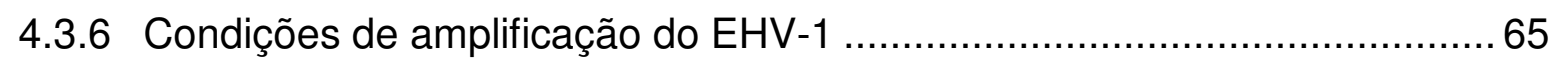




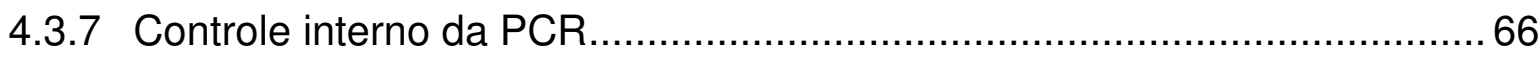

4.3.8 Oligonucleotídeos iniciadores (primers) da $\beta$-actina................................ 67

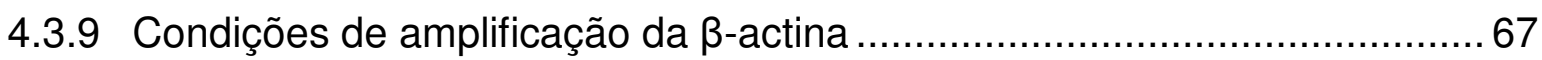

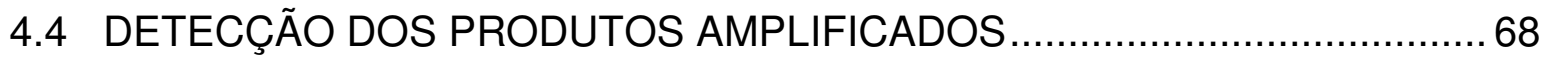

4.5 PROCESSAMENTO DAS AMOSTRAS CLÍNICAS ...................................... 69

4.5.1 Camundongos experimentalmente inoculados ........................................69

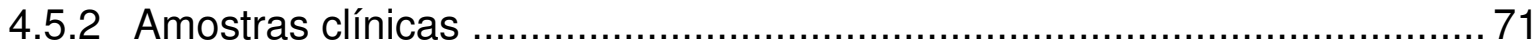

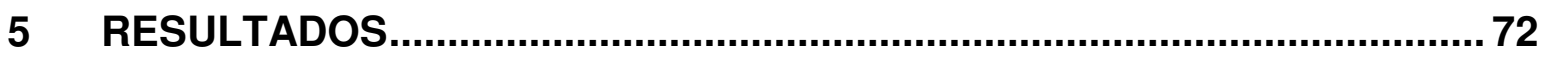

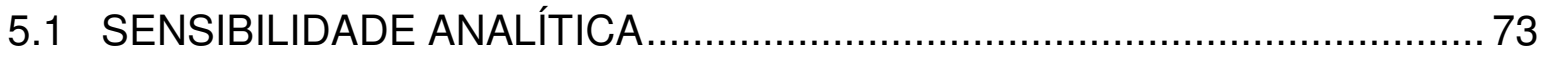

5.2 OBSERVAÇÃO DOS ANIMAIS INOCULADOS ……................................. 75

5.3 PESQUISA DO EHV-1 NOS ÓRGÃOS DOS CAMUNDONGOS

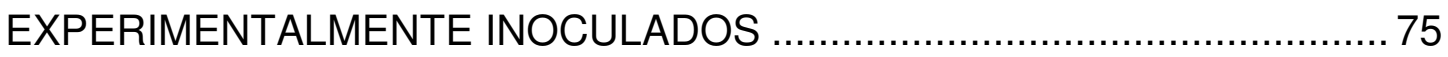

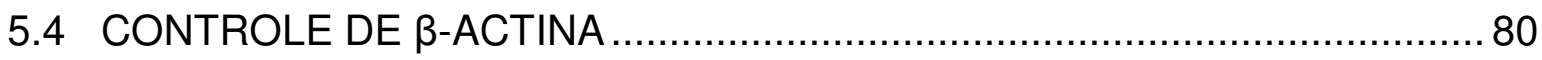

5.5 ASSOCIAÇÃO ENTRE PRESENÇA DO DNA E LESÕES

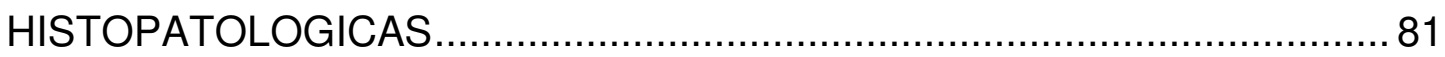

5.6 PESQUISA DO EHV-1 NAS AMOSTRAS CLÍNICAS …............................ 86

6 DISCUSSÃO

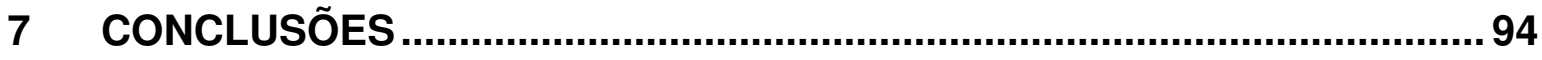

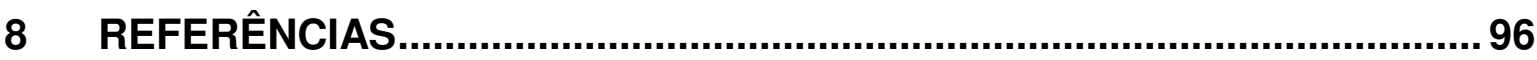


Que estranha é a sina que cabe a nós, mortais! cada um de nós está aqui para uma temporada; com que propósito, não se sabe [...] os ideais que têm íluminado meu caminho, e repetidamente me têm renovado a coragem para enfrentar a vida com ...ânimo, são a Bondade, a Beleza e a verdade. 


\section{INTRODUÇÃO}

O Brasil possui o maior rebanho de equinos da América Latina e o terceiro rebanho mundial. A movimentação financeira apenas dos equinos no Brasil é de 7,3 bilhões, gerando 3,2 milhões de empregos diretos e indiretos no complexo do agronegócio do cavalo (MAPA). O rebanho brasileiro compreende 7.802 .598 cabeças de equídeos, sendo 5.496.461 apenas equinos (Quadro 1) (sidra-IBGE, 2009).

Considerando apenas a região Sudeste, o estado de Minas Gerais possui o maior rebanho de equino, o segundo maior rebanho de muares e o oitavo rebanho de asininos do Brasil, enquanto São Paulo possui o quinto maior rebanho equino, o décimo maior rebanho de muares e o décimo terceiro rebanho de asininos do Brasil (IBGE, 2009).

\begin{tabular}{|cccc|}
\hline Regiōes brasileiras & \multicolumn{3}{c|}{ Efetivo do rebanho equídeo brasileiro 2009 } \\
\hline & Equinos & Muares & Asininos \\
\hline Brasil & $\mathbf{5 . 4 9 6 . 4 6 1}$ & $\mathbf{1 . 2 7 5 . 6 5 3}$ & $\mathbf{1 . 0 3 0 . 4 8 4}$ \\
\hline Norte & 712.235 & 186.761 & 38.484 \\
\hline Nordeste & 1.375 .594 & 631.054 & 930.559 \\
\hline Sul & 929.055 & 49.583 & 4.480 \\
\hline Sudeste & 1.357 .256 & 232.981 & 42.813 \\
\hline Centro-oeste & 1.122 .321 & 175.274 & 14.148 \\
\hline
\end{tabular}

Fonte: IBGE, 2009

Quadro1- Detalhes do rebanho equídeo brasileiro por região. Número efetivo de animais dos rebanhos de asininos, equinos e muares.

A exportação brasileira de equinos vivos em 2009 atingiu US $\$ 4,4$ milhões. $O$ país é o oitavo maior exportador de carne equina, desconsiderando as exportações 
feitas pela França, Bélgica, Itália, Rússia e Suíça (países exportadores de carne equina tecnificada) torna-se o quarto maior fornecedor com 10,9\% de participação, ficando atrás da Argentina (28,7\%), Canadá (24,6\%) e Polônia (14,6\%) (MAPA; Tendências de mercado).

Diante à grande produção de equinos no Brasil, perdas econômicas causadas pelo herpesvírus equino simbolizam grandes prejuízos, tanto na produção para o mercado interno quanto para a exportação.

O herpesvírus equino tipo1 (EHV-1) e o herpesvírus equino tipo 4 (EHV-4) são encontrados mundialmente, causando aborto (no terço final da gestação, entre o $8^{\circ}$ e $11^{\circ}$ meses), natimortalidade, morte perinatal, doença respiratória (mais comum é a rinopneumonite equina) e mieloencefalopatia herpética equina (MORI, 2000; ALEN 2004). O EHV-1 está amplamente distribuído no território nacional (MOREIRA; WEISS; KRUGER, 2000; CUNHA et al., 2002; LARA et al., 2003). 
"De tudo, ficaram três coísas: A certeza de que estamos sempre começando... A certeza de que precisamos continuar... A certeza de que seremos interrompidos antes de terminar... Portanto devemos:

Fazer da interrupção, um caminho novo... Da queda, um passo de dança... Do medo, uma escada...

Do sonho, uma ponte... Da procura, um encontro..."

Fernando Sabino. 


\section{REVISÃO DE LITERATURA}

\subsection{HISTÓRICO}

O primeiro isolamento de EHV-1 em Kentucky (Estados Unidos da América) foi em 1932, mas estudos retrospectivos relatam problemas com aborto desde 1921

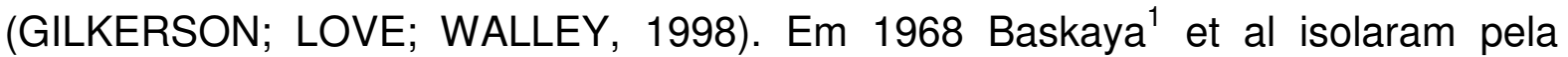
primeira vez EHV-1 na Turquia a partir de fetos abortados (TEKELIOGLU et al, 2005).

O primeiro isolado brasileiro de EHV-1 foi obtido por Nilson e Corrêa em 1966, a partir do fígado de feto abortado aos seis meses. O isolamento foi realizado em hamsters lactentes e a confirmação da identidade do isolado brasileiro com o de Kentucky D foi por meio da técnica de soroneutralização (NILSON; CORRÊA, 1966).

Lara et al. (2008) isolaram pela primeira vez no Brasil, EHV-1 de equino com sintomatologia nervosa. $\mathrm{O}$ isolamento foi em cultivo de células VERO, confirmado por soroneutralização e PCR para glicoproteína D.

O herpesvírus tipo-1 e tipo-4 (EHV-1 e EHV-4) possuem muitas similaridades antigênicas e de apresentação clínica da doença. Essas características contribuíram para que, inicialmente, ambos (EHV-1 e EHV -4) fossem considerados

\footnotetext{
${ }^{1}$ *Baskaya et al. ${ }^{1}$ (1968 apud TEKELIOGLU et al., 2005, p. 23)

${ }^{1}$ BASKAYA, H.; KESKINTEPE, H.; DOGUER, M.; IYIGOREN, B.; YILMAZ, S.; DEMIR, A. An outbreak of equine vírus abortion in Turkey. Isolation and identification of rhinopneumonitis virus in cell cultures. Ankara Univ. Vet. Fak. Derg., v. 15, p. 309-316.
} 
como EHV-1 o qual se dividia em dois subtipos: o subtipo-1 (EHV-1) responsável por abortos e subtipo-2 (EHV-4) por infecção do trato respiratório (MOREIRA; WEISS; KRUGER, 2000; CUNHA et al, 2002; ALLEN et al, 1994).

Allen et al (1994) demonstraram que os isolados do subtipo-1 (EHV-1), recuperados a partir de feto e neonatos, apresentavam unidades formadoras de placa de lise celular em culturas de rim equino, multiplicação intensa em equinos não imunes com alta eliminação de partículas virais e aborto quando inoculados por via intranasal em éguas prenhes. O subtipo-2 (EHV-4) não apresentava nenhuma destas características.

Studdert e Cols sugeriram a reclassificação do EHV-1 em dois tipos distintos taxonomicamente sendo que a nomenclatura atual classifica os subtipos 1 e 2 em EHV-1 e EHV-4, respectivamente (ALLEN et al, 1994).

Utilizando a enzima de restrição BamHI, Allen e Turtinen (1982) observaram que apenas $17 \%$ da sequência de nucleotídeos do EHV-1 subtipo 1 (EHV -1) e subtipo 2 (EHV-4) eram compartilhadas. Após estes relatos, Telford et al (1998), utilizando sequenciamento, observaram que a homologia do DNA entre os EHV-1 e - 4 variam entre $55 \%$ - $84 \%$ e a homologia entre aminoácidos varia de 55\% - 96\%.

O EHV-1 e o EHV-4 apresentam diferenças no padrão de clivagem por enzimas de restrição, por isso levantou-se a hipótese de baixa estabilidade genômica em passagens seriadas dos isolados do vírus em culturas de células e/ou animais de laboratório. As passagens realizadas em culturas de células equinas e/ou de feto equino não causaram alteração no genoma, porém as culturas de células não equinas e a passagem dos isolados em hamsters causavam alteração genômica nos EHV. Contudo essas alterações observadas no genoma eram estáveis tornando a análise por enzima de restrição confiável (ALLEN et al, 1994). 


\subsection{CLASSIFICAÇÃO VIRAL E ESTRUTURA GENÔMICA}

O herpesvírus equino (EHV) pertence ordem Herpesvirales, família Herpesviridae, que se divide em três subfamílias Alfaherpesvirinae, Bethaherpesvirinae e Gammaherpesvirinae. O EHV-1 e EHV-4 pertencem à subfamília Alfaherpesvirinae, gênero Varicellovirus.

Os herpesvírus de maior importância na medicina de equinos estão representados nas subfamílias Alphaherpesvirus e Gammaherpesvirus, representados no quadro 2

\begin{tabular}{|l|l|l|l|}
\hline Vírus & \multicolumn{1}{|c|}{ Sinônimo } & Sub-família & Hospedeiro \\
\hline EHV- 1 & $\begin{array}{l}\text { Vírus da rinopneumonite equina ou do } \\
\text { abortamento equino. } \\
\text { (antigo subtipo 1 do EHV-1) }\end{array}$ & Alfa & Equus caballus \\
\hline EHV- 2 & Antigo citomegalovírus & Gama & Equus caballus \\
\hline EHV- 3 & Vírus do exantema coital & Alfa & Equus caballus \\
\hline EHV- 4 & $\begin{array}{l}\text { Vírus da rinopneumonite equina (antigo } \\
\text { subtipo 2 do EHV-1) }\end{array}$ & Alfa & Equus caballus \\
\hline EHV- 5 & Antigo citomegalovírus equino & Gama & Equus caballus \\
\hline EHV- 6 & Herpesvírus asinino tipo 1 (HVA-1) & Alfa & Equus asinus \\
\hline EHV- 7 & Herpesvírus asinino tipo 2 (HVA-2) & Gama & Equus asinus \\
\hline EHV- 8 & Herpesvírus asinino tipo 3 (HVA-3) & Alfa & Equus asinus \\
\hline EHV- 9 & Herpesvírus de gazela tipo 1 (HVG-1) & Alfa & Equus zebra(?) \\
\hline
\end{tabular}

Fonte: adaptado ICTV, 2009.

Quadro 2- Principais herpesvírus de importância veterinária. 
O herpesvírus equino é um DNA vírus fita dupla, linear, envelopado, com tamanho de $150 \mathrm{Kbp}$ para o EHV-1 e $145 \mathrm{Kbp}$ para o EHV-4 (Figura 1). A porcentagem de citosina e guanidina $(C+G)$ presente no seu DNA são de $57 \%$ para o EHV-1 e 50\% para o EHV-4, (PATEL; HELDENS, 2005; TELFORD et al, 1992). Os EHV-1 e EHV-4 apresentam homologia da sequência do DNA entre $55 \%-84 \%$ e homologia de aminoácidos entre 55\% - 96\% (TELFORD et al, 1998).

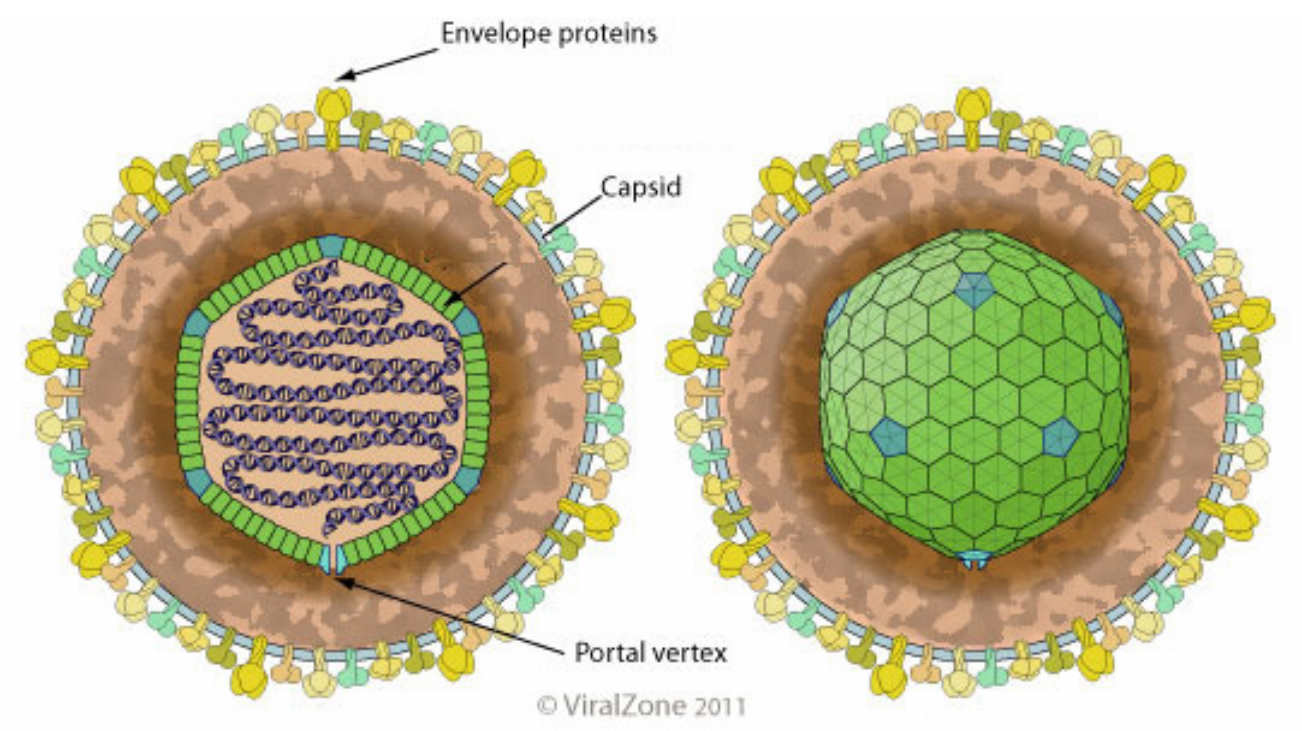

fonte: www.expasy.org,

Figura 1- Desenho esquemático de um vírion da família Herpesviridae. A figura mostra o envelope glicoprotéico, capsídeo viral e o DNA linear no interior do virion.

O genoma do EHV-1 e do EHV-4 é dividido em uma região longa única (UL) e uma região curta única (US). A região US está entre uma sequência de repetição interna (IR) e outra externa (TR) (figura2) (SÁENZ; URCUQUIINCHIMA, 2006; TELFORD et al, 1992). 
O genoma do EHV-1 contém 80 ORFs (open reading frames), representando 76 genes distintos. As ORFs 64, 65, 66 e 67 estão presentes em duplicata no genoma do EHV-1, sendo uma copia na região IRs e outra copia invertida na TRs. O genoma do EHV-4 apresenta 79 ORFs que representam 76 genes distintos, sendo três destes genes (genes 64, 65 e 66) presentes na região IRs e invertidos na região TRs (Figura 3) (ALLEN, 2002).

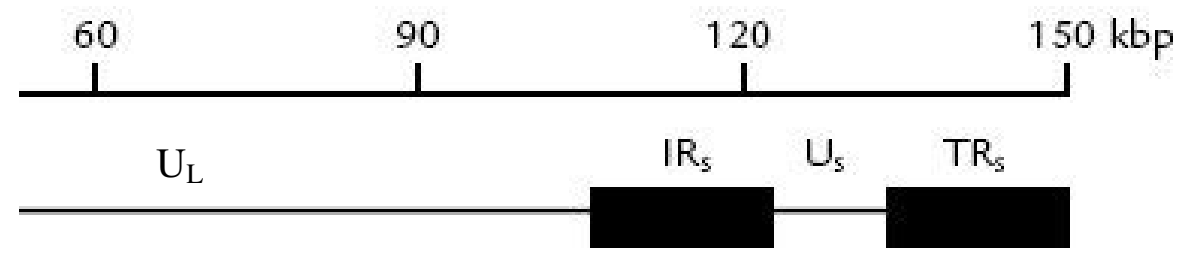

Figura 2- Organização esquemática do genoma do EHV-1. Observe as regiões, única longa "UL" e a região única curta "US". As sequências repetidas interna IRS e a terminal TRS estão destacadas em preto (retirado de: SÁENZ; URCUQUIINCHIMA, 2006).

Os EHV-1 e -4 apresentam 10 glicoproteínas de membrana dentre elas as mais pesquisadas $\mathrm{gB}, \mathrm{gC}, \mathrm{gH}, \mathrm{gL}, \mathrm{gG}, \mathrm{gD}, \mathrm{gl}, \mathrm{gE}$; as proteínas reguladoras são 4 , denominadas pelas ORFs 5, 12, 63, 64 (ALLEN, 2002). A ORF 64 desempenha função de importante ativador transcricional denominado immediate early. Localizase na porção 3' da região IRs, repetindo-se na porção 5' da região TRs (Figura3) (TELFORD et al, 1992). 


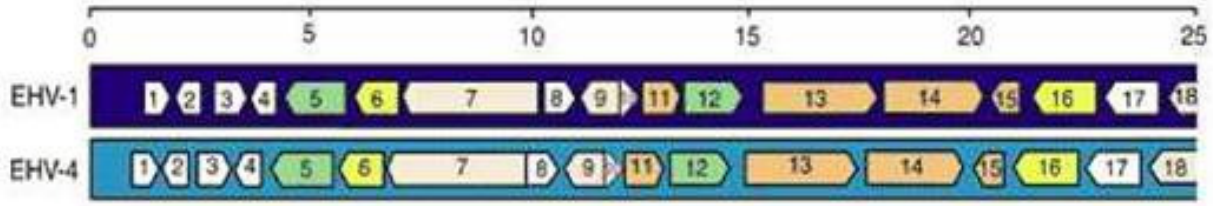
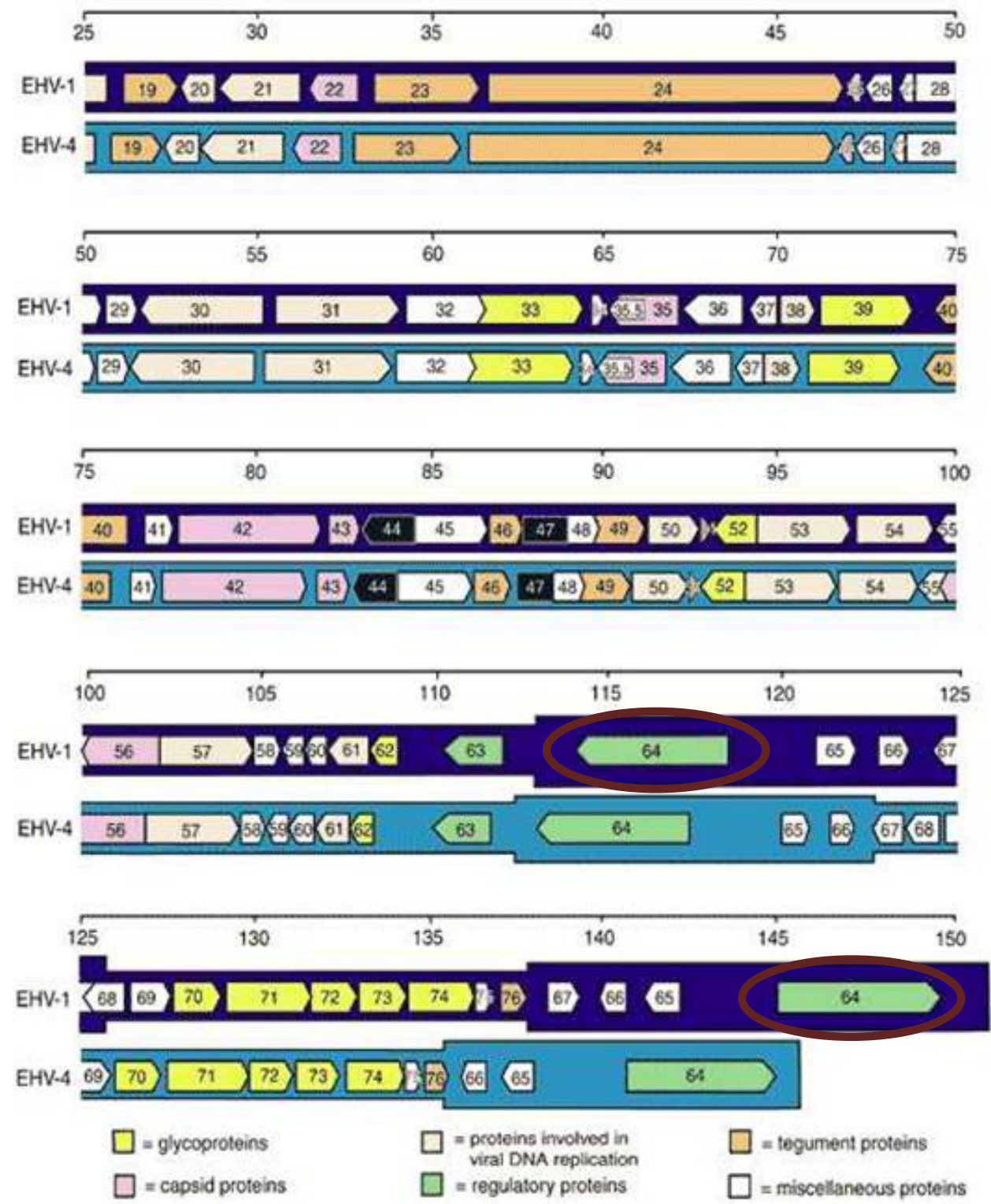

wwwivis_org

fonte: Allen, 2002.

Figura 3- Localização e função dos 76 genes distintos do EHV-1 e EHV-4. Destaque para ORF64 do EHV-1. 


\subsection{EPIDEMIOLOGIA}

O EHV-1 é responsável por doença respiratória, aborto, doença neonatal fatal e distúrbios neurológicos (RIMSTAD; EVENSEN, 1993; CUNHA et al, 2002; HIRSH et al, 2003; DIEL et al, 2006; PUSTERLA et al, 2007; WANG et al, 2007; LÉON et al, 2008; LUNN et al, 2009), a infecção por EHV-1 ocorre, na maioria dos animais, nos primeiros anos de vida, mostrando sua alta importância econômica no rebanho equino mundial (RIMSTAD; EVENSEN, 1993; CUNHA et al, 2002; WANG et al, 2007; LUNN et al, 2009).

A transmissão dos EHV-1 e EHV-4 ocorrem: a) via direta: contato com secreções infecciosas (nasal ou de abortos) e inalação de aerossóis; $b$ ) indireta: água e fômites contaminados com secreções infecciosas. Após a replicação inicial nas células epiteliais do trato respiratório os vírus são disseminados por via hematógena para outros órgãos como tecido linfóide local (EHV-1 e EHV-4) ou para - SNC (EHV-1), conforme as características do vírus (neurotrópico ou endoteliotrópico) (REED; TORIBIO, 2004; LUNN et al, 2009).

A infecção por EHV-4 inicia-se, em geral, no trato respiratório superior e em macrófagos localizados nos linfonodos locais, o vírus estabelece viremia e dissemina-se para os tecidos linfóides. O EHV-1 inicia a infecção no trato respiratório superior e dissemina-se, sistemicamente, via linfócitos para outros tecidos (BLUNDEN et al,1995; REED; TORIBIO, 2004). 
A viremia persiste por no mínimo 14 dias, sendo fator predisponente para disseminação viral nos tecidos placentários, fetal e sistema nervoso central (BLUNDEN et al,1995; REED; TORIBIO, 2004; PATEL; HELDENS, 2005; LUNN et al, 2009).

A transmissão para os potros nascidos livres de EHV normalmente ocorre nos primeiros 30 dias de vida (PATEL; HELDENS, 2005). Estudos realizados por Moreira; Weiss; Kruger, (2000) e por Lara et al (2003) comprovaram que, com o avanço da idade dos potros, os títulos de anticorpos para EHV aumentam, isso ocorre pelo maior contato com animais portadores, sintomáticos ou não. De acordo com Gilkerson et al. (1999), os anticorpos contra EHV-1 em potros produzidos após o primeiro mês de vida ocorrem devido ao contato com o vírus e não por anticorpos maternos de passagem passiva; estes anticorpos tem vida média de 31 dias.

Uma vez infectados pelo EHV-1 e/ou EHV-4, os animais tornam-se potenciais fontes de infecção e reservatórios da doença, podendo eliminar os vírus mesmo em infecções inaparentes, em decorrência do estado de latência (Figura 4). Durante esse estado, apenas a região LAT (latency-associated transcript), localizada nas ORFs (open reading frames) 63 e 64, que são regiões potencialmente codificantes, é transcrita, resultando na ausência da forma lítica viral do vírus (BORCHES et al, 1999; TELFORD et al, 1992; PAGAMJAV et al, 2005). 


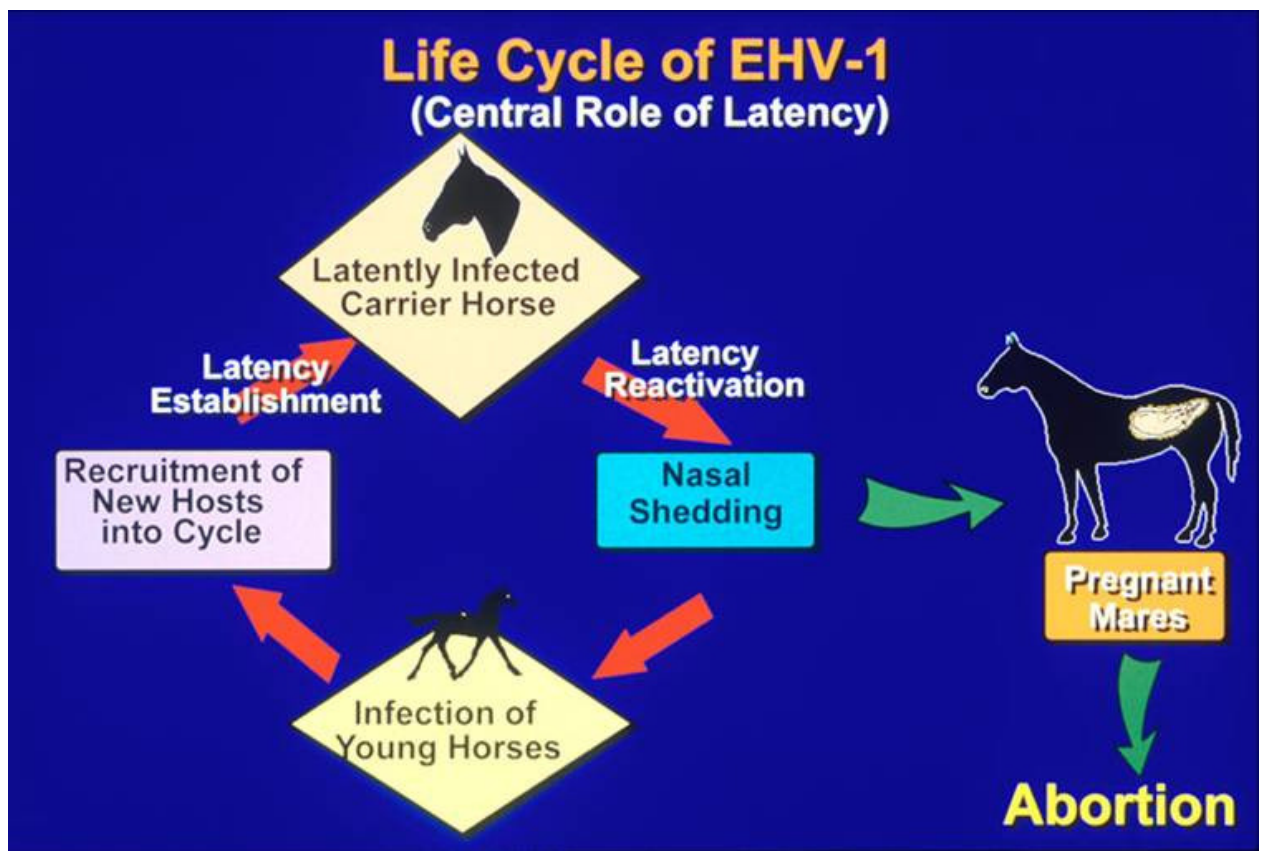

fonte: homepage.usask.ca

Figura 4- ciclo esquemático da transmissão do EHV-1. O ciclo consiste na transmissão entre equídeos através do contato oronasal. Quando a égua se infecta com EHV-1 antes ou durante a prenhez, pode ocorrer aborto.

Durante o estagio de latência, o EHV-1 aloja-se no interior dos leucócitos do sistema linforreticular e do gânglio do nervo trigêmeo. Linfócitos T são considerados principais pontos de latência para o EHV-1 no organismo do hospedeiro, enquanto que o EHV-4 aloja-se nos macrófagos localizados nos linfonodos locais e nas células epiteliais do pulmão (BLUNDEN et al,1995; REED; TORIBIO, 2004; PATEL; HELDENS, 2005).

A latência é considerada uma característica importante para a manutenção e disseminação viral em populações de equinos. Fatores que aumentam e/ou favorecem o estresse dos animais, como castração, realojamento, administração de corticóides, doenças, prenhez, parto e lactação podem reativar a infecção por EHV 
provocando novos surtos (GILKERSON et al, 1999; SLATER, 2001; PATEL; HELDENS, 2005; LUNN et al, 2009).

No Brasil o EHV-1 encontra-se amplamente disseminado na população equina. Diversos isolados originários de casos de doença neurológica e de abortamento ou mortalidade Peri natal já foram estudados (REINER et al., 1972; CUNHA et al., 1993; WEIBLEN et al., 1994; CARVALHO et al., 2004; COSTA et al., 2006; LARA et al., 2008). Por outro lado, existem apenas dois relatos sobre a ocorrência do EHV-4 no país sem confirmação pelo isolamento e identificação viral (DIAS, 2000; LIMA et al., 2006).

Os sinais clínicos em infecção respiratória aguda por EHV-1 podem ser febre, anorexia, rinite e faringites, podendo estender-se para as vias aéreas inferiores causando traqueobronquites, bronqueolites e pneumonite, que normalmente se resolvem em duas semanas; quando associada a bactérias os sintomas respiratórios podem agravar (ALLEN, 2002; REED; TORIBIO, 2004; PATEL; HELDENS, 2005)

Apresentações sistêmicas do EHV-1 são abortos no terço final da gestação (entre $8^{\circ}$ e $11^{\circ}$ meses), natimortos e morte Peri natal, sendo que esta última ocorre por infecções tardias, o potro nasce debilitado e morre entre o primeiro e segundo dias de vida (ALLEN, 2002; REED; TORIBIO, 2004; LUNN et al., 1009); a mieloencefalopatia é menos comum, contudo, os sinais neurológicos podem aparecer entre 6 a 10 dias do início dos sinais respiratórios (ALLEN, 2002).

As alterações patológicas macroscópicas que podem ser observadas no feto são icterícia, petéquias na mucosa, edema pleural e subcutâneo, esplenomegalia 
com folículos linfóides proeminentes, hepatomegalia e necrose hepática focal (MOREIRA et al., 1998; CORRÊA; NILSON, 1964).

Alterações microscópicas podem ser encontradas em vários órgãos: pulmão com hiperemia intensa, congestão, bronquiolite e pneumonite; baço com necrose intensa de polpa branca e congestão dos seios; fígado em desarranjo e tumefação das trabéculas hepáticas, necrose hepática focal, leve megalocitose, infiltrado mononuclear e raros polimorfonucleares. Normalmente as lesões são acompanhadas de corpúsculo de inclusão intranuclear (CORRÊA; NILSON, 1964; MOREIRA et al., 1998; REED; TORIBIO, 2004); as lesões do SNC se resume em vasculite e trombose nos pequenos vasos, resultando em hipóxia e morte neuronal, semelhantes as que ocorrem na placenta (REED; TORIBIO, 2004; LUNN et al., 2009).

Diel et al. (2006), usando a técnica de soroneutralização em amostras de animais hígidos, demonstraram a circulação do EHV no Rio Grande do Sul, ressaltando a indicação de infecção latente. Do mesmo modo, Cunha et al. (2002) verificaram no noroeste do estado de São Paulo a circulação do EHV, atentando-se para a habilidade destes vírus manterem infecção latente, dificultando o controle epidemiológico.

O estudo realizado por Lara et al. (2003) no estado de São Paulo e outro realizado por Moreira; Weiss; Kruger, (2000) em Curitiba, usando a soroneutralização, indicou um aumento na soropositividade conforme o aumento da idade dos animais, podendo atribuir ao fato de aumentar as chances de contato com o vírus.

Uma das dificuldades da epidemiologia e controle do EHV-1 é a sua capacidade de desenvolver infecção latente, aumentando o risco de disseminação 
entre animais de propriedades vizinhas, em exposições e/ou eventos que reúnem grande número de animais (CUNHA et al., 2002; DIEL et al., 2006; PUSTERLA et al., 2007; WANG et al., 2007), por isso investigações da doença e medidas de controle devem ser incrementadas para diminuir as perdas com a infecção por EVH1 (CUNHA et al., 2002).

Como tentativa de diminuir a transmissão do EHV-1, alguns cuidados devem ser mantidos como: a) evitar inserir novos animais no grupo de éguas prenhes e quando necessário inserir novos animais ao rebanho, utilizar programa quarentena; b) a égua que abortou deve ser separada dos outros animais; c) o feto e placenta, após a necropsia, devem ser incinerados e se possível enterrados, todo material de aborto pode ser fonte de infecção até a determinação da causa; $d$ ) evitar episódios de estresse (introdução de animais, transporte, provas, etc.) para evitar ativação de possível infecção latente (MOREIRA et al., 1998; LUNN et al., 2009).

A vacinação contra EHV-1 e EHV-4 previne a infecção em muitos casos, contudo, estudos não indicam sua eficiência nos casos de encefalomiopatia herpética. A imunização é realizada, sobretudo, na tentativa de diminuir as manifestações clínicas da infecção, diminuindo assim, a transmissão horizontal da doença. As vacinas podem ser de vírus vivo inativado ou vírus morto, associadas ou não a outras doenças. (Quadro 3) (LUNN et al., 2009).

Conforme as especificações do fabricante a vacinação pode ser feita em potros a partir dos três meses de idade com 1 a 3 reforços após 15 a 30 dias. As fêmeas prenhes, com vacinação regular, devem ser revacinadas aos $5^{\circ}, 7^{\circ}$ e $9^{\circ}$ mês de gestação para diminuir a incidência de abortamento na propriedade. Todos os animais devem ser vacinados a cada seis meses. (FLUVAC, 1995; HERPESHORSE, 2008). 


\begin{tabular}{|l|l|l|l|}
\multicolumn{1}{|c|}{ VACINA } & FABRICANTE & \multicolumn{1}{|c|}{ PROTEÇÃO } \\
\hline LEXINGTON 8 & Vencofarma & $\begin{array}{l}\text { Encefalomielite do leste e do } \\
\text { oeste, tétano, influenza, EHV-1 } \\
\text { e EHV-4. }\end{array}$ & Inativada \\
\hline HERPES HORSE & Vencofarma & EHV-1 e EHV- 4 & Inativada \\
\hline $\begin{array}{l}\text { Fluvac } 8 \\
\text { Innovator }\end{array}$ & FORT DODGE & EHV -1 e EHV- 4 & Vírus morto \\
\hline Fonte: FLUVAC $1995 ;$ HERPESHORSE & 2008. & \\
\hline
\end{tabular}

Fonte: FLUVAC, 1995; HERPESHORSE, 2008.

Quadro 3- Algumas das vacinas utilizadas no Brasil para controle do EHV-1 e EHV-4.

\subsection{MODELO ANIMAL PARA EXPERIMENTAÇÃO}

Em infecções experimentais, um dos animais utilizados é o camundongo, pois pode mimetizar os sinais encontrados em equinos naturalmente infectados (AWAN; BAXI; FIELD, 1995; BARTELS et al., 1998; GALOSI et al., 2006; GOSZTONYI; BORCHES; LUDWIG, 2009).

Awan; Chong; Field, (1990) descreveram que os camundongos adultos eram refratários ao herpesvírus equino, por isso recomendava-se o uso de animais recém nascidos ou recém desmamados para os experimentos. Hoje se sabe que os camundongos podem ser usados com diferentes idades, variando de 21 até 84 dias de idade, dependendo do objetivo da inoculação que pode ser transmissão vertical, atividade imunológica do hospedeiro ou disseminação nos diferentes órgãos 
(AWAN; BAXI; FIELD, 1995; BARTELS et al., 1998; GALOSI et al., 2006; GOSZTONYI; BORCHES; LUDWIG, 2009).

A inoculação do herpesvírus equino pode ser feita pelas vias intracerebral (IC) (recém nascidos) onde se tem, normalmente, sinais relacionados ao sistema nervoso e pela via intranasal (IN) (recém desmamados) onde os sinais são basicamente respiratórios, sempre levando em consideração a patogenicidade e o tropismo da cepa viral (neurotrópico ou endoteliotrópico). Camundongos também têm sinais reprodutivos quando inoculados por via IN no final da gestação, causando aborto ou nascimento de filhotes debilitados (WALKER; LOVE; WHALLEY, 1999).

Os experimentos de inoculação do EHV-1 em laboratório visam mimetizar a infecção natural, por isso a inoculação experimental em camundongos é realizada pela via intranasal (IN). Na infecção experimental de camundongos, os sinais clínicos dependem da amostra viral empregada, variando de infecções assintomáticas a fatais (AWAN; BAXI; FIELD, 1995; BARTELS et al., 1998; GALOSI et al., 2006; GOSZTONYI; BORCHES; LUDWIG, 2009; MORI, 2011).

Utilizando a inoculação IN é possível isolar o vírus da traquéia, bulbos olfatórios, cérebro, olho e pulmão. Através da nested- PCR pode-se recuperar 0 DNA viral do baço, linfonodos cervicais, adrenal, coração, rins, gânglio trigêmeo e pâncreas. Quando se inocula camundongos fêmeas prenhes, o vírus pode ser isolado dos fetos abortados, placenta e útero (WALKER; LOVE; WHALLEY, 1999).

Os sinais clínicos que podem ser observados nos camundongos inoculados são polipnéia e dispnéia, apatia, desidratação postura encurvada e, ocasionalmente, conjuntivite que ocorre dentro de 24 horas pós-inoculação (PI) e se resolvem em 6-7 dias PI (WALKER et al., 1998, GALOSI et al., 2004). 
$\mathrm{Na}$ avaliação histopatológica do pulmão pode-se observar alveolite e bronquiolite aguda e focal, inclusões eosinofílicas intranucleares nas células do epitélio bronquiolar (WALKER; LOVE; WHALLEY, 1999; GALOSI et al., 2004), células inflamatórias perivasculares e peribronquiolares, primeiramente infiltrado inflamatório neutrofílico e depois tende a ser mononuclear (WALKER; LOVE; WHALLEY, 1999).

\section{5- MÉTODOS DIAGNÓSTICOS}

O diagnóstico dos EHV-1 pode ser feito por métodos indiretos usando as técnicas de soroneutralização viral, fixação do complemento e Enzyme Linked Immunosorbent Assay (ELISA) e métodos diretos através do isolamento e pesquisa do ácido nucléico do agente pela Reação em Cadeia pela Polimerase (PCR) (LÉON et al., 2008; LUNN et al., 2009).

É importante ressaltar que vários agentes podem causar aborto e distúrbios neurológicos, por isso o diagnóstico diferencial é realizado. Para aborto, podem ser investigadas doenças bacterianas como leptospirose e viral como arterite viral equina (CUNHA et al., 2002; ASANO et al., 2007). Para distúrbios neurológicos devem ser investigados o vírus da raiva, encefalomielite equina do leste e do oeste e leucoencefalomalácia (PIMENTEL et al., 2009; DEL FAVA et al., 2010). 
2.5.1- Métodos indiretos de diagnóstico

A fixação do complemento (CF) é usada em amostras pareadas de soro equino (7-21dias de intervalo) para levantamentos epidemiológicos da rinopneumonite equina. No entanto, essa técnica apresenta algumas desvantagens, dentre elas destacam-se a não diferenciação entre anticorpos vacinais e anticorpos da infecção natural e, também, não diferencia EHV-1 do EHV-4. Essas características dificultam o diagnóstico e levantamentos epidemiológicos em cavalos vacinados (YASUNAGA et al., 2000).

A soroneutralização também não permite a diferenciação entre o EHV-1 e EHV-4, por isso pode-se encontrar alta soroprevalência de EHV com baixa queixa de abortamento na propriedade, sugerindo que a infecção se apresenta de forma subclínica ou o EHV em questão pode ser o EHV-4, que raramente causa aborto (OIE 2008; CUNHA et al., 2002).

A soroneutralização pode ser feita em placas de 96 poços com culturas de células VERO, E-Derm ou RK-13. O EHV-1 é capaz de se multiplicar e causar efeito citopático em cultivo de células equinas (E-DERM) e não equinas (RK-13 e VERO), por ouro lado, o EHV-4 se multiplica e causa efeito citopático em culturas de células de origem equina (E-Derm). A soroneutralização pode ser uma ferramenta útil para confirmação de isolados de EHV (OIE, 2008).

Devido à grande reatividade cruzada entre EHV-1 e EHV-4 a diferenciação entre os dois vírus era necessária para inquéritos epidemiológicos do EHV. Por 
esse motivo desenvolveram-se testes de ELISA empregando regiões das glicoproteínas virais para identificação e diferenciação entre EHV-1 e EHV-4. Com o uso de anticorpos monoclonais Sinclair et al. (1993), utilizando uma proteína recombinante derivada da glicoproteínas B (rgB1-50) e Yasunaga et al. (2000), empregando um teste de ELISA com a glicoproteina G recombinante, confirmaram a viabilidade de inquéritos epidemiológicos para EHV-1 e EHV-4 em animais não vacinados e vacinados com vacinas compatíveis com o teste.

\subsection{2 - Métodos diretos de diagnóstico}

O isolamento viral é considerado padrão ouro (gold standard) para detecção do EHV-1 (GALOSI et al., 2001; LUNN et al., 2009), pode ser feito através de Swabs nasal, "papa de leucócitos", tecido fetal ou porção tecidual obtidos por necropsia dos animais adultos (baço, fígado, timo, SNC e pulmão). É um método que requer tempo para obtenção de resultados, que, algumas vezes pode ser falso negativo, devido à presença de vírus inviável nos fragmentos de tecido testado (RIMSTAD; EVENSEN, 1993, PUSTERLA et al., 2007).

O isolamento do EHV-1 pode ser feito em diferentes culturas de células, dentre as quais se podem citar fibroblasto equino (E-DERM), rim de coelho (RK13), rim de hamsters (BHK21), rim de porco (PK15) e rim de bovino Madin-Darby (MDBK) dentre outras, para o isolamento do EHV-4 são usadas culturas de células equinas como fibroblasto (E-Derm) (OIE, 2008). 
Os resultados falsos negativos ou impossibilidade de isolamento viral decorrem de vários fatores, como a má conservação térmica dos fragmentos de tecidos a serem testados (deve ser congelado e não resfriado); armazenamento em formol (que inativa as partículas virais presentes na amostra, impossibilitando o isolamento) e susceptibilidade do sistema de isolamento (animais/células adaptadas) (RIMSTAD; EVENSEN, 1993, PUSTERLA et al., 2007).

Diante das dificuldades associadas ao isolamento viral, as técnicas de detecção do DNA viral facilitam o diagnóstico em amostras impróprias para isolamento (GALOSI et al., 2001).

A análise do polimorfismo dos fragmentos de restrição do DNA genômico (RFLP) pode ser usada na diferenciação entre os tipos de EHV. Cada EHV tem um padrão próprio de clivagem se mostrando diferentes na eletroforese. Para a determinação dos tipos de EHV podem ser usadas uma grande variedade de enzimas de restrição na RFLP, como BamHI, EcoRI (ALLEN; TURTINEM, 1982); Pstl, Sacl e Banll (PAGAMJAV et al., 2005) entre outras.

A Reação em Cadeia pela Polimerase (PCR) é uma ferramenta importante para o diagnóstico direto devido à alta sensibilidade e especificidade diagnóstica. Permitindo a detecção do DNA viral em quantidades pequenas, ou quando o vírus não está mais ativo na amostra clínicas, em decorrência do armazenamento incorreto, amostras incluídas em parafina ou na fase de latência viral (ASANO et al., 2007; LUNN et al., 2009).

A PCR pode ser feita após a necropsia do feto, natimorto ou equino adulto com fragmento de órgãos (sistema nervoso central - SNC, fígado, pulmões, rim, baço e tecido linfóide) (RIMSTAD; EVENSEN, 1993; TEKELIOGLU et al., 2005), swab nasofaringeano e sangue "papa de leucócitos". Na Interpretação do resultado 
deve-se lembrar que esta técnica não diferencia vírus ativo, inativo ou latente (RIMSTAD; EVENSEN, 1993; TEKELIOGLU et al., 2005; LUNN et al., 2009). Estudos recentes demonstram que a PCR a partir de swab da secreção nasal é mais sensível do que "papa de leucócitos" e swab nasofaríngeo para detecção de EHV-1(BROWN et al., 2007; LUNN et al., 2009).

A técnica de PCR pode fornecer resultados positivos, mesmo quando a soroneutralização tem resultado negativo, ou quando os anticorpos maternos ainda estão presentes, favorecendo assim um diagnóstico precoce da infecção herpética (MARENZONI et al., 2008).

Uma melhor opção, quando possível, é a associação do isolamento viral e da PCR. Como as técnicas permitem concordância entre os resultados, dependendo da viabilidade/conservação das amostras, pode-se utilizar a técnica mais conveniente para um resultado mais preciso (GALOSI et al., 2001).

A utilização da PCR em amostras clínicas incluídas em parafina é um recurso extremamente importante para estudos epidemiológicos retrospectivos sobre a ocorrência de agentes patogênicos, uma vez que os blocos de parafina são estocados por longo tempo (RIMSTAD; EVENSEN, 1993).

A PCR a partir de material incluído em parafina pode ser usada para pesquisa de vírus (RIMSTAD; EVENSEN, 1993), bactérias (JAMBHEKAR et al., 2006), investigar doenças hereditárias, relação entre mutações celulares e o câncer (MESQUITA et al., 2001; FERNANDES et al., 2004).

No entanto, a extração de ácido nucléico proveniente de órgãos incluídos em parafina é mais laboriosa e está diretamente relacionada com o tempo e o tipo de fixação usado. Deve-se levar em consideração a possível fragmentação do DNA 
pesquisado nas amostras (FERNANDES et al., 2004). A fixação em formalina favorece a ligação entre proteínas nucleares e o DNA, essa ligação pode ser reversível usando tampão de lise com proteinase K (ISOLA et al.,1994). Segundo Rogers et al. (1990), tecidos fixados por menos de sete dias em formalina tem um pequeno decréscimo na qualidade do DNA extraído, permitindo ainda a amplificação do material genético.

O presente estudo teve como escopo desenvolver uma metodologia de PCR para a detecção do EHV-1 em amostras clínicas incluídas em parafina, o que permitirá a realização de estudos retrospectivos em arquivos de laboratório de histopatologia. 
A diferença entre o possivel e o impossível está na vontade humana. Louis Pasteur 


\section{OBJETIVOS}

1- Padronização da técnica de PCR para detecção de DNA de EHV-1 em fragmentos de órgãos incluídos em parafina obtidos pela inoculação experimental em camundongos.

2- Avaliar a relação entre a presença de DNA do EHV-1 e a observação de lesões histopatológicas em fragmentos de tecidos incluídos em parafina

3- Avaliar a PCR padronizada para detecção de EHV-1em amostras clínicas incluídas em parafina. 
É mais fácíl mudar a natureza de plutônio do que mudar a natureza do homem. Albert Einstein 


\section{MATERIAIS E METODOS}

\subsection{AMOSTRAS VIRAIS}

Foram utilizados três diferentes isolados do EHV-1 para a padronização da PCR, sendo dois Argentinos, AR N1 isolado em 1996 e AR N2 isolado em 2007, e um Brasileiro A3/97 isolado em 2004.

Os isolados do EHV-1 provenientes da Argentina eram mantidos em cultura de célula RK-13 e o isolado do Brasil mantido em cultura de células E-DERM. 


\subsection{INOCULAÇÃO EXPERIMENTAL}

\subsubsection{Animais utilizados}

Para a inoculação experimental foram selecionados 15 camundongos (Mus musculus) da linhagem $\mathrm{CH} 3 /$ Rockfeller com 21 dias de idade, mantidos no biotério do Departamento de Epidemiologia Experimental Aplicada às Zoonoses (VPS) da Faculdade de Medicina Veterinária e Zootecnia - USP.

Para a inoculação os camundongos foram separados em três grupos (A, B e C) com cinco animais cada, dos quais, quatro animais de cada grupo foram inoculados com os isolados descritos no item (4.1), e um animal utilizado como controle negativo inoculado com meio essencial mínimo (MEM) (Quadro 4).

Os camundongos foram mantidos em caixas plásticas, próprias para a experimentação animal, no infectório do mesmo departamento. Os animais inoculados com os diferentes isolados de EHV-1 ficaram em caixas separadas dos animais controles. As caixas foram acomodadas em prateleiras abertas com uma distância de $20 \mathrm{~cm}$ entre elas. 


\begin{tabular}{|l|l|l|l|}
\hline LINHAGEM & IDADE & ANIMAIS & INÓCULOS \\
\hline CH3/Rockfeller & $21 \mathrm{~d}$ & 1 & AR N1, AR N2, A3/97 \\
\hline CH3/Rockfeller & $21 \mathrm{~d}$ & 2 & AR N1, AR N2, A3/97 \\
\hline CH3/Rockfeller & $21 \mathrm{~d}$ & 3 & AR N1, AR N2, A3/97 \\
\hline CH3/Rockfeller & $21 \mathrm{~d}$ & 4 & AR N1, AR N2, A3/97 \\
\hline CH3/Rockfeller & $21 \mathrm{~d}$ & C- & MEM (meio essencial mínimo) \\
\hline
\end{tabular}

Quadro 4- Separação dos três grupos de camundongos que foram inoculado com os isolados de EHV-1 argentinos e brasileiro. Os animais de 1 - 4 são os camundongos inoculados com os isolados do EHV-1, C- camundongo usado como controle negativo da inoculação.

4.2.2 Método de inoculação

Para diminuir o estresse pela mudança de ambiente (do biotério para 0 infectório), os camundongos foram deixados na sala do infectório por 24 horas antes do início do experimento.

A inoculação dos camundongos foi realizada sob sedação com a associação de ketamina (100 mg/Kg) e xilazina $(2 \mathrm{mg} / \mathrm{Kg})$, por via intraperitoneal (IP). Depois de confirmada a sedação, os animais foram inoculados por via intra -nasal (IN), com $25 \mu \mathrm{L} /$ animal da suspensão do vírus e o camundongo utilizado como controle negativo foi inoculado com $25 \mu \mathrm{L}$ / animal de MEM. No momento da inoculação, a 
titulação viral foi de $10^{3}$ (DCIT50/25 $\left.\mu \mathrm{L}\right)$ para o AR N1; $10^{2,7}$ (DCIT50/25 $\left.\mu \mathrm{L}\right)$ para AR N2 e $10^{3}$ (DCIT50/25 $\left.\mu \mathrm{L}\right)$ para A3/97.

Os camundongos foram observados por quatro dias, após esse período foram sacrificados sob over dose da associação de ketamina (200 mg/Kg) e xilazina (4 mg/Kg), realizando a necropsia para coleta do pulmão e do sistema nervoso central (SNC).

Os órgãos foram divididos em duas partes aproximadamente iguais, sendo uma parte colocada em cassetes histológicos para fixação em formol 10\% tamponado por 24 horas e outra parte congelada a $-20 \stackrel{\circ}{ } \mathrm{C}$, para posterior processamento quadro 5. Os órgãos dos camundongos foram separados por animal e por isolado viral utilizados. 


\begin{tabular}{|c|c|c|c|}
\hline & & \multicolumn{2}{|c|}{ ÓRGÃOS } \\
\hline ISOLADO & IDENTIFICAÇÃO & PULMÃO & SNC \\
\hline \multirow{5}{*}{ AR N1 } & 1 & $\mathrm{C} / \mathrm{P}$ & $\mathrm{C} / \mathrm{P}$ \\
\hline & 2 & $C / P$ & $\mathrm{C} / \mathrm{P}$ \\
\hline & 3 & $C / P$ & $\mathrm{C} / \mathrm{P}$ \\
\hline & 4 & $C / P$ & $\mathrm{C} / \mathrm{P}$ \\
\hline & C- & $\mathrm{C} / \mathrm{P}$ & $\mathrm{C} / \mathrm{P}$ \\
\hline & & ÓRGÃOS & \\
\hline ISOLADO & IDENTIFICAÇÃO & PULMÃO & SNC \\
\hline \multirow{5}{*}{ AR N2 } & 1 & $C / P$ & $\mathrm{C} / \mathrm{P}$ \\
\hline & 2 & $\mathrm{C} / \mathrm{P}$ & $\mathrm{C} / \mathrm{P}$ \\
\hline & 3 & $\mathrm{C} / \mathrm{P}$ & $\mathrm{C} / \mathrm{P}$ \\
\hline & 4 & $C / P$ & $\mathrm{C} / \mathrm{P}$ \\
\hline & C- & $C / P$ & $\mathrm{C} / \mathrm{P}$ \\
\hline & & ÓRGÃOS & \\
\hline ISOLADO & IDENTIFICAÇÃO & PULMÃO & SNC \\
\hline \multirow{5}{*}{ A3/97 } & 1 & $C / P$ & $\mathrm{C} / \mathrm{P}$ \\
\hline & 2 & $\mathrm{C} / \mathrm{P}$ & $\mathrm{C} / \mathrm{P}$ \\
\hline & 3 & $\mathrm{C} / \mathrm{P}$ & $\mathrm{C} / \mathrm{P}$ \\
\hline & 4 & $C / P$ & $\mathrm{C} / \mathrm{P}$ \\
\hline & C- & $C / P$ & $\mathrm{C} / \mathrm{P}$ \\
\hline
\end{tabular}

Quadro 5- Detalhamento dos órgãos dos camundongos que foram incluídos em parafina e mantidos a $-20^{\circ} \mathrm{C}$ até a extração. P: órgãos formalizados e incluídos em parafina; C: órgãos congelados; 1-4: camundongos de 21 dias inoculados com os três diferentes isolados de EHV-1; C-: camundongo de 21 dias utilizado como controle negativo da inoculação. 


\subsection{PADRONIZAÇÃO DA REAÇÃO EM CADEIA PELA POLIMERASE}

A técnica de extração e amplificação do DNA viral foi testada previamente nos isolados do EHV-1 mantidos em cultivo celular, para avaliar a sensibilidade analítica da PCR e dos Primers utilizados para a detecção do EHV-1 nos órgãos dos camundongos inoculados.

O processamento das amostras foi realizado em salas separadas para as diferentes etapas: extração, preparo dos reagentes para a PCR e nested-PCR, distribuição da nested-PCR, e analise dos produtos amplificados.

\subsubsection{Avaliação da sensibilidade analítica da PCR}

A sensibilidade analítica da PCR para detecção do EHV-1 foi realizada com diluição na base 10 dos isolados de EHV-1 utilizados na inoculação dos

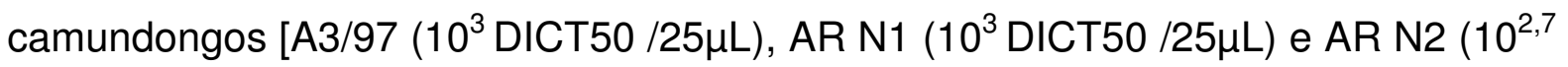
DICT50 /25 $\mu \mathrm{L})]$. A extração e amplificação foram realizadas conforme descrito nos itens 4.3.3 e 4.3.6. 
Os três isolados do EHV-1 foram diluídos em TE (10 mM Tris-HCL, 1 mM de EDTA) e em macerado de pulmão a $20 \%$, para mimetizar a presença de possíveis inibidores da PCR presentes no tecido.

A diluição viral foi realizada em um volume total $250 \mu \mathrm{L}$, realizando diluições sucessivas na escala $1: 10\left(10^{-1}\right)$ do primeiro ao oitavo microtubo $\left(10^{-1}\right.$ a $\left.10^{-8}\right)$. Para obter estas diluições, foram preparados oito microtubos de 1,5 mL, adicionados a cada um $225 \mu \mathrm{L}$ do diluente (TE ou macerado de pulmão a $20 \%$ ), no primeiro microtubo foram acrescidos $25 \mu \mathrm{L}$ do vírus, homogeneizado e obtida a diluição $10^{-1}$, a partir da qual foram transferidos $25 \mu \mathrm{L}$ para o microtubo seguinte para obter a diluição $10^{-2}$ e assim sucessivamente, até o oitavo microtubo, onde se alcançou a diluição $10^{-8}$, conforme ilustrado na figura 5 .

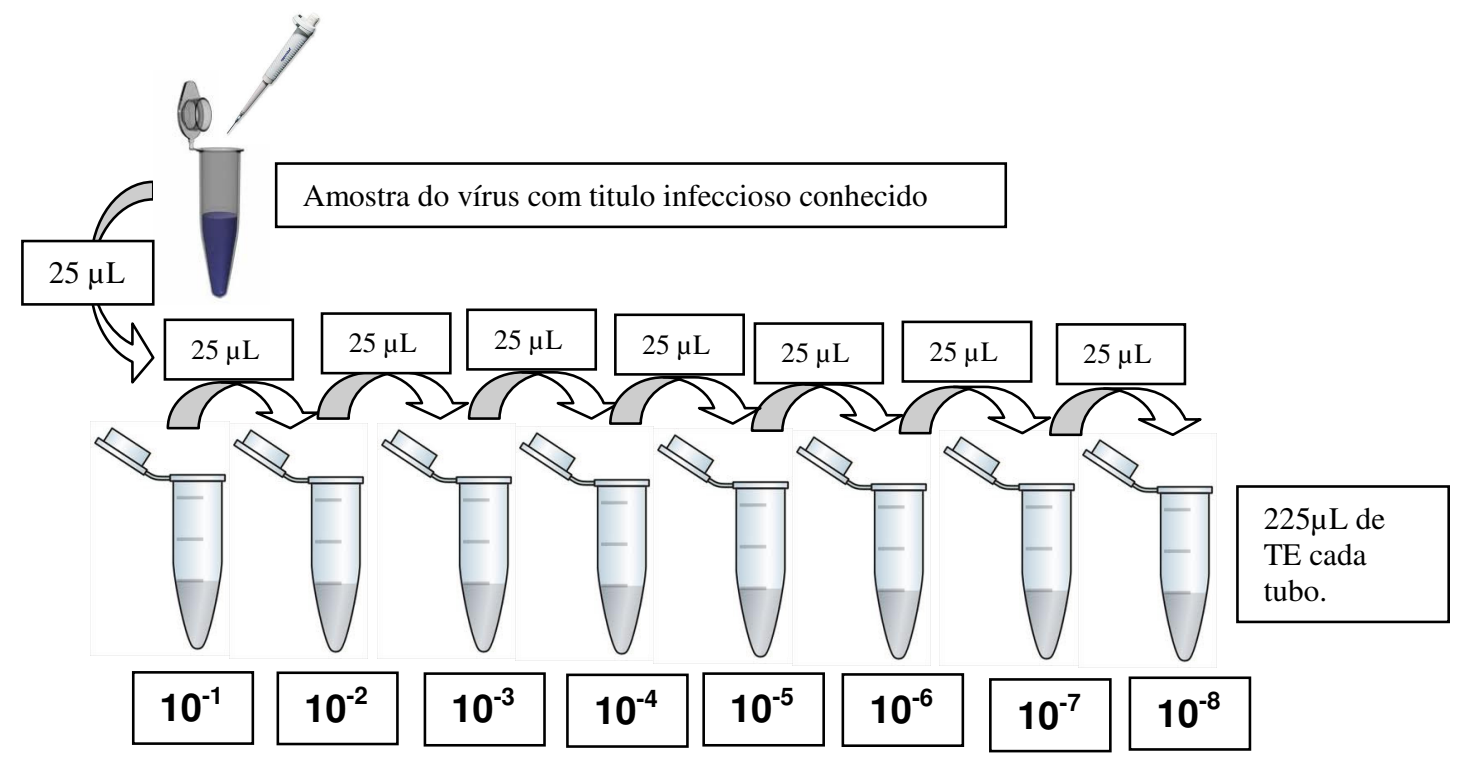

Figura5- Diluição esquemática na base 10 dos três isolados dos EHV-1 usados para inoculação experimental. Os isolados do EHV-1 foram diluídos em TE $(10 \mathrm{mM}$ Tris-HCL, $1 \mathrm{mM}$ de EDTA) e diluídos em macerado de pulmão a $20 \%$. A diluição foi feita acrescendo $25 \mu \mathrm{L}$ do vírus ao primeiro microtubo do diluente $(225 \mu \mathrm{L})$. Depois de homogeneizado foi transferido do primeiro microtubo para o segundo $25 \mu \mathrm{L}$, prosseguindo dessa maneira até completar as 8 diluições do vírus $\left(10^{-1}\right.$ a $\left.10^{-8}\right)$. 
4.3.2 Controles da extração e amplificação

Para a padronização da extração e da nested-PCR foi utilizado em todas as etapas um controle negativo (a cada quatro amostras) que consistia de água ultra pura e um controle positivo (por grupo de amostras processadas) que consistia de uma alíquota do isolado viral.

\subsubsection{Extração do DNA de material congelado}

Para a extração de DNA a partir de isolados e/ou material congelado do EHV-1 foi utilizado o protocolo modificado descrito por Sambrook; Fritsch; Maniatis, (1989).

1. Fez-se uma suspensão a $20 \%$ dos fragmentos dos órgãos congelados;

2. Adicionou-se $500 \mu \mathrm{l}$ do tampão de lise (Tris-HCL 10mM; NaCl 100mM; EDTA 25mM; SDS 1\%; proteinase $\mathrm{K} 10 \mu \mathrm{g} / \mu \mathrm{l}$ ) a $100 \mu \mathrm{l}$ da suspensão do órgão;

3. Incubou-se por quatro horas a 55ํㅡ, sob agitação intermitente 15 minutos cada intervalo (Termomix- Eppendorf Termomixer comfor ${ }^{\circledR}$ );

4. Adicionou-se $250 \mu \mathrm{l}$ de fenol e $250 \mu \mathrm{l}$ de clorofórmio; 
5. Agitou-se por 15 segundos;

6. Centrifugou-se a $12000 \mathrm{xg}$ por 15 minutos;

7. Recuperou-se o sobrenadante e adicionou-se $500 \mu \mathrm{l}$ de propanol;

8. Incubou-se a $-20^{\circ} \mathrm{C}$ por duas horas;

9. Centrifugou-se a $12000 \mathrm{xg}$ por 30 minutos;

10. Desprezou-se o sobrenadante e adicionou-se $500 \mu$ de etanol $75 \%$;

11. Homogeinou-se suavemente e centrifugou-se a 12000 xg por 15 minutos;

12. Desprezou-se o sobrenadante;

13. Secou-se em termobloco (Thermolyne Type $16500^{\circledR}$, Dri-Bath) por dois minutos a $56^{\circ} \mathrm{C}$;

14. Acrescentou- se $30 \mu \mathrm{l}$ de TE, armazenou a $-20^{\circ} \mathrm{C}$.

As amostras de DNA extraídas foram armazenadas em microtubos de 1,5 mL a -20ํㅡ até realização da amplificação do DNA.

4.3.4 Extração de DNA do material incluído em parafina

A extração dos órgãos incluídos em parafina foi realizada em cortes sequênciais de $4 \mu \mathrm{m}$. Em cada microtubo, utilizado na extração foram colocados de 5 a 9 fragmentos de $4 \mu \mathrm{m}$, total de $20 \mu \mathrm{m}$ e $36 \mu \mathrm{m}$ em cada microtubo. A extração foi 
realizada seguindo o protocolo de Chan et al. (2001) modificado conforme descrito abaixo:

1. Os fragmentos foram cortados com lâminas novas e colocados em tubos de $1,5 \mathrm{~mL}$.

2. Adicionou-se $1 \mathrm{~mL}$ de xilol aos cortes e submeteu-se a agitação continua de $1000 \mathrm{rpm}$ por 20 minutos a $25^{\circ} \mathrm{C}$ em termomix (Eppendorf Termomixer comfort ${ }^{\circledR}$.

3. Centrifugou-se a $10.000 \times \mathrm{g}$ por 10 minutos a $28^{\circ} \mathrm{C}$ e descartou-se 0 sobrenadante.

4. Repetiram-se os passos 1 e 2 por duas vezes.

5. Adicionou $1 \mathrm{~mL}$ de etanol puro (etanol 100\%) e submeteu-se à agitação continua de 1000 rpm por 5 minutos a $25^{\circ} \mathrm{C}$ em termomix.

6. Centrifugou-se a $10.000 \times \mathrm{g}$ por 5 minutos a $28^{\circ} \mathrm{C}$ e descartar $\mathrm{o}$ sobrenadante.

7. Repetiram-se os passos 4 e 5 por duas vezes.

8. Secou-se em termobloco (Thermolyne Type ${ }^{\circledR}$ 16500, Dri Bath) por 2 minutos a $56^{\circ} \mathrm{C}$.

9. Seguiu-se a extração descrita no item 4.3.1, com modificação no passo 3 , onde as amostras foram mantidas a $55^{\circ} \mathrm{C}$ overnight.

O DNA extraído foi armazenado em microtubos de $1,5 \mathrm{~mL}$ a $-20^{\circ} \mathrm{C}$ até realização da PCR e nested-PCR para detecção de EHV-1 e PCR para o gene de $\beta$-actina. 
4.3.5 Oligonucleotídeos iniciadores (primers) EHV-1

Para a detecção de EHV-1 foram utilizados dois pares de primers direcionados para a região da ORF 64, sendo o U-pr-1/U-pr-2 utilizados na PCR e U-pr-3/U-pr-4 na nested- PCR, conforme descrito por Borchers et al. (1999) (Quadro 6). Os primers U-pr-1/U-pr-2utilizados na PCR amplificam fragmento de 410pb e os primers U-pr-3/U-pr-4 utilizados na nested-PCR amplificam fragmento de 263pb.

\begin{tabular}{|c|c|c|c|c|c|}
\hline PRIMERS & $\begin{array}{l}\text { SEQUÊNCIA DE } \\
\text { NUCLEOTÍDEOS } \\
\left(5^{\prime}-3^{\prime}\right)\end{array}$ & $\begin{array}{l}\text { REGIÃO DE } \\
\text { HIBRIDIZAÇÃO }\end{array}$ & $\begin{array}{l}\text { SEQUÊNCI } \\
\text { A ALVO }\end{array}$ & $\begin{array}{l}\text { FRAGMENT } \\
0 \\
\text { ESPERADO }\end{array}$ & FONTE \\
\hline $\begin{array}{l}\text { U-Pr1 } \\
\text { (senso) }\end{array}$ & $\begin{array}{l}\text { ACG.CCC.CCT.TCG.TT } \\
\text { C.CTC }\end{array}$ & $\begin{array}{l}113.937- \\
113.954^{\mathrm{a}} \\
149.223- \\
149206^{\mathrm{a}}\end{array}$ & ORF 64 & \multirow{2}{*}{410} & $\begin{array}{l}\text { Borchers } \\
\text { et al. } \\
\text { (1999) }\end{array}$ \\
\hline $\begin{array}{l}\text { L-Pr2 } \\
\text { (anti- } \\
\text { senso) }\end{array}$ & $\begin{array}{l}\text { CGC.TCC.ACC.TCG.GT } \\
\text { C.CTG }\end{array}$ & $\begin{array}{l}114.346- \\
114.329^{\mathrm{a}} \\
148.814- \\
148.831^{\mathrm{a}}\end{array}$ & ORF 64 & & $\begin{array}{l}\text { Borchers } \\
\text { et al. } \\
\text { (1999) }\end{array}$ \\
\hline $\begin{array}{l}\text { U-Pr3 } \\
\text { (senso) }\end{array}$ & $\begin{array}{l}\text { GGC.GGA.GTC.TGC.GT } \\
\text { T.GTG }\end{array}$ & $\begin{array}{l}114.039- \\
114.056^{\mathrm{a}} \\
149.121- \\
149.104^{\mathrm{a}}\end{array}$ & ORF 64 & \multirow[t]{2}{*}{263} & $\begin{array}{l}\text { Borchers } \\
\text { et al. } \\
\text { (1999) }\end{array}$ \\
\hline $\begin{array}{l}\text { U-Pr4 } \\
\text { (anti- } \\
\text { senso) }\end{array}$ & $\begin{array}{l}\text { CCG.GAG.CCC.GAC.GA } \\
\text { C.GAG }\end{array}$ & $\begin{array}{l}114.301- \\
114.284^{\mathrm{a}} \\
148.859- \\
148.876^{\mathrm{a}}\end{array}$ & ORF 64 & & $\begin{array}{l}\text { Borchers } \\
\text { et al. } \\
\text { (1999) }\end{array}$ \\
\hline
\end{tabular}

Fonte: BORCHERS et al., 1999

Quadro 6- Primers codificadores da ORF 64 para identificação de EHV-1. 


\subsubsection{Condições de amplificação do EHV-1}

As reações de PCR e nested PCR foram realizadas em um termociclador automático modelo PTC-200 (Peltier Thermal Cycler MJ Research), desnaturação inicial com temperatura de $96^{\circ} \mathrm{C}$ por quatro minutos, seguindo 40 ciclos que compreende três etapas segunda desnaturação de $94^{\circ} \mathrm{C}$ por 30 segundos; anelamento de $64^{\circ} \mathrm{C}$ por 30 segundos, extensão de $72^{\circ} \mathrm{C}$ por 1 minuto e por fim extensão de $72^{\circ} \mathrm{C}$ por 6 minutos (Quadro 7).

A primeira amplificação (PCR) foi com volume final de $50 \mu \mathrm{L}$, contendo $0,5-$ 1,0 $\mu \mathrm{g}$ de DNA, 0,5 $\mu \mathrm{M}$ de cada primer externo, $200 \mu \mathrm{M}$ de cada deoxinucleotídeo (dNTPs), 2,5 U de Taq DNA polimerase platinum (Invitrogen Life Technologies), 1× tampão de PCR (50 mM KCl, 20 mM Tris- $\mathrm{HCl}$, $\mathrm{pH}$ 9,0), 1,5 mM MgCl 2 e água ultrapura qsp.

A segunda etapa de amplificação (nested - PCR), o volume de 1,0 $\mu \mathrm{L}$ do produto da primeira PCR foi transferido para microtubos novos contendo os primers específicos e demais reagentes no mesmo volume da reação anterior. 


\begin{tabular}{|c|c|c|}
\hline \multicolumn{2}{|c|}{ PCR e nested- PCR } & EHV-1 \\
\hline \multicolumn{2}{|c|}{ Desnaturação inicial } & $96 \circ \mathrm{C} / 4 \mathrm{~min}$ \\
\hline Desnaturação & \multirow{3}{*}{ (40ciclos) } & $94^{\circ} \mathrm{C} / 30 \mathrm{seg}$. \\
\hline Hibridização (“anelamento”) & & $64^{\circ} \mathrm{C} / 30 \mathrm{seg}$. \\
\hline Extensão & & $72^{\circ} \mathrm{C} / 1 \mathrm{~min}$. \\
\hline \multicolumn{2}{|c|}{ Extensão Final } & $72^{\circ} \mathrm{C} / 6 \mathrm{~min}$. \\
\hline
\end{tabular}

Fonte: BORCHES, et al., 1999

Quadro 7- Descrição do ciclo de amplificação do DNA da ORF 64 do EHV-1 com as etapas, temperaturas e tempo correspondente utilizados para a PCR e nested PCR

\subsubsection{Controle interno da PCR}

Foi utilizado um controle interno direcionado para o gene da beta-actina na tentativa de diminuir os possíveis falsos negativos decorrentes da não recuperação do DNA viral e por possíveis fatores de inibição da PCR presentes nas amostras congeladas e incluídas em parafina. Todos os fragmentos negativos para a presença do EHV-1 foram testados para o gene da $\beta$ - actina. 
4.3.8 Oligonucleotídeos iniciadores (primers) da $\beta$-actina

Para a detecção do gene de $\beta$-actina utilizado como controle interno da extração, foram utilizados dois primers nomeados de AC1 e AC2, que amplificam um fragmento de aproximadamente 567pb (Quadro 8) (NAGARAJAN; SIMARD, 2001).

\begin{tabular}{|c|c|c|c|c|}
\hline PRIMERS & SEQUÉNCIA 5' $-3^{\prime}$ (NT) & $\begin{array}{c}\text { REGIÃO DE } \\
\text { HIBRIDIZAÇÃO* }\end{array}$ & $\begin{array}{c}\text { SEQUÉNCIA } \\
\text { ALVO }\end{array}$ & $\begin{array}{c}\text { FRAGMENTO } \\
\text { (PB) }\end{array}$ \\
\hline AC1 & ATG TGC AAG GCC GGC & $11283285-$ & Beta-actina & \\
(senso) & TTC G & $11283303^{\mathrm{a}}$ & & \\
AC2 (anti- & TTA ATG TCA CGC ACG ATT & $11283870-$ & Beta-actina & 567 \\
senso) & TCC & $11283853^{\mathrm{a}}$ & & \\
\hline
\end{tabular}

Fonte: NAGARAJAN; SIMARD, 2001.

Quadro 8- Primer codificador do gene da $\beta$-actina de camundongo usado como controle da PCR. * ref/NT039718.7/ camundongo musmusculus strain C57B2/6J; cromossomo X; contig MGSCv37.

4.3.9 Condições de amplificação da $\beta$-actina

Para as reações de PCR com volume final de $50 \mu \mathrm{L}$, contendo $0,5-1,0 \mu \mathrm{g}$ de DNA, 0,5 $\mu \mathrm{M}$ de cada primer externo, $200 \mu \mathrm{M}$ de cada deoxinucleotídeo (dNTPs), 2,5 U de Taq DNA polimerase platinum (Invitrogen Life Technologies), 1x tampão de PCR $(50 \mathrm{mM} \mathrm{KCl}, 20 \mathrm{mM}$ Tris-HCl, pH 9,0), 1,5 mM MgCl 2 e água ultra-pura q.s.p.

A reação de PCR foi realizada em termociclador automático modelo PTC-200 (Peltier Thermal Cycler MJ Research), (Quadro 9) desnaturação inicial temperatura 
de $95^{\circ} \mathrm{C}$ por 1,5 minutos, hibridização inicial temperatura de $56^{\circ} \mathrm{C}$ por 30 segundos, extensão inicial temperatura de $72^{\circ} \mathrm{C}$ por 1 minuto, 34 ciclos que compreende desnaturação temperatura de $94^{\circ} \mathrm{C}$ por 1 minuto, hibridização (anelamento) temperatura de $56^{\circ} \mathrm{C}$ por 1 minuto e extensão temperatura $72^{\circ} \mathrm{C}$ por 45 segundo, extensão final temperatura $72^{\circ} \mathrm{C}$ por 7 minutos.

\begin{tabular}{|c|c|c|}
\hline \multicolumn{2}{|c|}{ Etapas Programa PCR } & $\beta$-actina \\
\hline \multicolumn{2}{|c|}{ Desnaturação inicial } & $95^{\circ} \mathrm{C} / 1,5 \mathrm{~min}$ \\
\hline \multicolumn{2}{|c|}{ Hibridização inicial } & $56 \% 30 \mathrm{seg}$ \\
\hline \multicolumn{2}{|c|}{ Extensão inicial } & $72 \% 1 \mathrm{~min}$ \\
\hline Desnaturação & \multirow{3}{*}{ (34 ciclos) } & $94^{\circ} \mathrm{C} / 1 \mathrm{~min}$ \\
\hline $\begin{array}{l}\text { Hibridização } \\
\text { (“anelamento") }\end{array}$ & & $56 \circ \mathrm{C} / 1 \mathrm{~min}$ \\
\hline Extensão & & $72^{\circ} \mathrm{C} / 45$ seg. \\
\hline \multicolumn{2}{|c|}{ Extensão Final } & $72^{\circ} \mathrm{C} / 7 \mathrm{~min}$. \\
\hline
\end{tabular}

Quadro 9- Programa de amplificação do DNA viral, etapas, temperaturas e tempo correspondente a PCR.

\subsection{DETECÇÃO DOS PRODUTOS AMPLIFICADOS.}

Foram analisados $10 \mu \mathrm{L}$ do produto da nested-PCR para detecção do EHV1 e do produto da PCR para o gene da $\beta$-actina. As dimensões dos amplificados foram comparadas a um padrão de DNA com escala de 100 pares de base (LA) 
disposto no gel juntamente com as amostras analisadas a cada eletroforese (SAMBROOK; FRITSCH; MANIATIS, 1989; BORCHES, et al., 1993).

Os fragmentos amplificados foram analisados por meio da eletroforese em cuba horizontal, em gel de agarose a 1,5\% imerso em tampão Tris-Borato-EDTA (0,045 M Tris-borato, $1 \mathrm{mM}$ EDTA $)$ e a uma tensão elétrica adequada às dimensões do gel (1 a $10 \mathrm{~V} / \mathrm{cm}$ de gel).

A visualização foi realizada por transiluminador de luz ultravioleta, após corar o gel em solução de brometo de etídeo a uma concentração final de $0,5 \mu \mathrm{g} / \mathrm{mL}$. As amostras foram consideradas positivas quando os fragmentos amplificados apresentavam tamanho esperado.

\subsection{PROCESSAMENTOS DAS AMOSTRAS CLÍNICAS}

4.5.1 Camundongos experimentalmente inoculados.

Os órgãos dos camundongos coletados durante a necropsia foram divididos em duas partes aproximadamente iguais para posterior processamento. Uma parte foi armazenada a $-20^{\circ} \mathrm{C}$ até a extração do DNA conforme descrito no item 4.3 .3 e a outra parte foi fixada em formalina 10\% tamponada por 24 horas, realizada a inclusão em parafina e extração do DNA conforme descrito no item 4.3.4. 
A inclusão em parafina foi realizada segundo protocolo modificado de Prophet (1995) (Quadro 10).

\begin{tabular}{|l|l|}
\hline \multicolumn{1}{|c|}{ AGENTES } & \multicolumn{1}{|c|}{ TEMPO } \\
\hline 1. Álcool 70\% I & 15 minutos \\
\hline 2. Álcool 70\% II & 15 minutos \\
\hline 3. Álcool 80\% I & 15 minutos \\
\hline 4. Álcool 80\% II & 15 minutos \\
\hline 5. Álcool 95\% I & 15 minutos \\
\hline 6. Álcool 95\% I & 15 minutos \\
\hline 7. Álcool Absoluto I & 30 minutos \\
\hline 8. Álcool Absoluto II & 30 minutos \\
\hline 9. Xilol I & 30 minutos \\
\hline 10. Xilol II & 30 minutos \\
\hline 11. Xilol III & 30 minutos \\
\hline 12. Parafina (56 ㅇ) & 2 horas \\
\hline 13. Inclusão em parafina dos fragmentos dos órgãos \\
\hline
\end{tabular}

Quadro 10: Protocolo de desidratação, diafanização e embebição em parafina dos fragmentos de órgãos fixados em formol $10 \%$ tamponado.

A partir dos órgãos incluídos em parafina foram preparadas lâminas histológicas para avaliar a presença de lesões causadas pelo EHV-1 nos animais inoculados. Para confecção das lâminas foram cortados em micrótomo, (LEICA®) três cortes sequenciais de $4 \mu \mathrm{m}$ de espessura cada, estendidos em banho-maria 
$\left(60^{\circ} \mathrm{C}\right)$ e colocados em lâmina de vidro previamente tratadas com albumina para facilitar a adesão do corte histológico. As lâminas foram colocadas em estufa (60) overnight e coradas pela hematoxilina e eosina (HE) segundo protocolo modificado de Allen (1995).

\subsubsection{Amostras clínicas}

As amostras clínicas utilizadas para comprovar a aplicabilidade deste protocolo de extração e nested-PCR para pesquisa do EHV-1 em órgãos incluídos em parafina, foram cedidas pelo Centro de Pesquisa e Desenvolvimento de Sanidade Animal do Instituto Biológico de São Paulo - Laboratório de Anatomia Patológica.

Foram selecionados cinco casos clínicos decorrentes de aborto, dois casos de 2007, dois casos de 2008 e um caso de 2010. Essas amostras haviam sido previamente processadas, pelo Laboratório de Raiva e Encefalites do Instituto Biológico - São Paulo, a partir de pool's dos órgãos, foi realizado o isolamento viral em cultivo celular e PCR com primers padronizados por Kirisawa (1993).

Para a coleta dos fragmentos para a PCR, foram descartados os primeiros quatro fragmentos de tecido cortados do bloco de parafina, para evitar possível contaminação. O processamento das amostras segue o protocolo descrito nos itens

\subsection{3, 4.3.4 e 4.3.5.}


o pesquisador que não souber o que está procurando não compreenderá o que encontrar.

claude Bernard 


\section{RESULTADOS}

\subsection{SENSIBILIDADE ANÁLITICA}

Os resultados da sensibilidade analítica demonstraram que a PCR utilizada neste estudo é capaz de amplificar o DNA viral alvo numa diluição de até $10^{-5}$

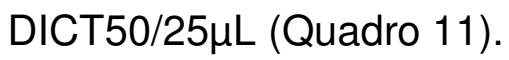

$\mathrm{O}$ isolado argentino AR N1 apresentou positividade até a $5^{\circ}$ diluição (na

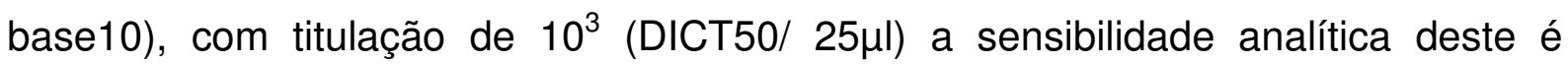

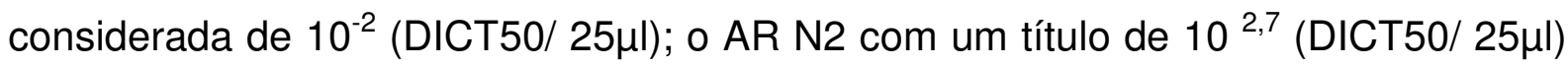

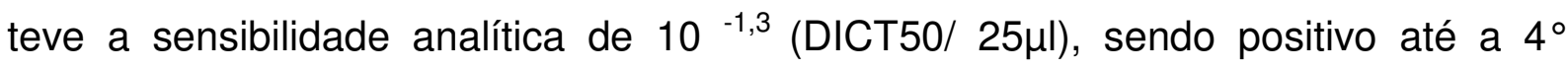
diluição; o isolado brasileiro $\mathrm{A} 3 / 97$ foi positivo até a $4^{\circ}$ diluição, com um titulo viral de

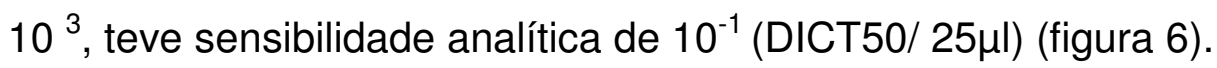

\begin{tabular}{|c|c|c|c|c|c|c|c|c|c|c|}
\hline ISOLADO & $\begin{array}{c}\text { TITULO } \\
\text { ISOLADO }\end{array}$ & $10^{-1}$ & $10^{-2}$ & $10^{-3}$ & $10^{-4}$ & $10^{-5}$ & $10^{-6}$ & $10^{-1}$ & $10^{-8}$ & 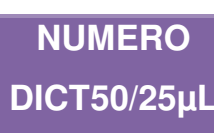 \\
\hline AR N1 & $10^{3}$ & + & + & + & + & + & - & - & - & $10^{-2}$ \\
\hline AR N2 & $10^{2,1}$ & + & + & + & + & - & - & - & - & $10^{-1,3}$ \\
\hline A3/97 & $10^{3}$ & + & + & + & + & - & - & - & - & $10^{-1}$ \\
\hline
\end{tabular}

Quadro 11- Detalhamento da positividade na sensibilidade analítica com os primers direcionados para ORF64 do EHV-1. O isolado AR N1 foi positivo até a 5ำ diluição; os isolados AR N2 e A3/97 foram positivos até a 4ํ diluição. 


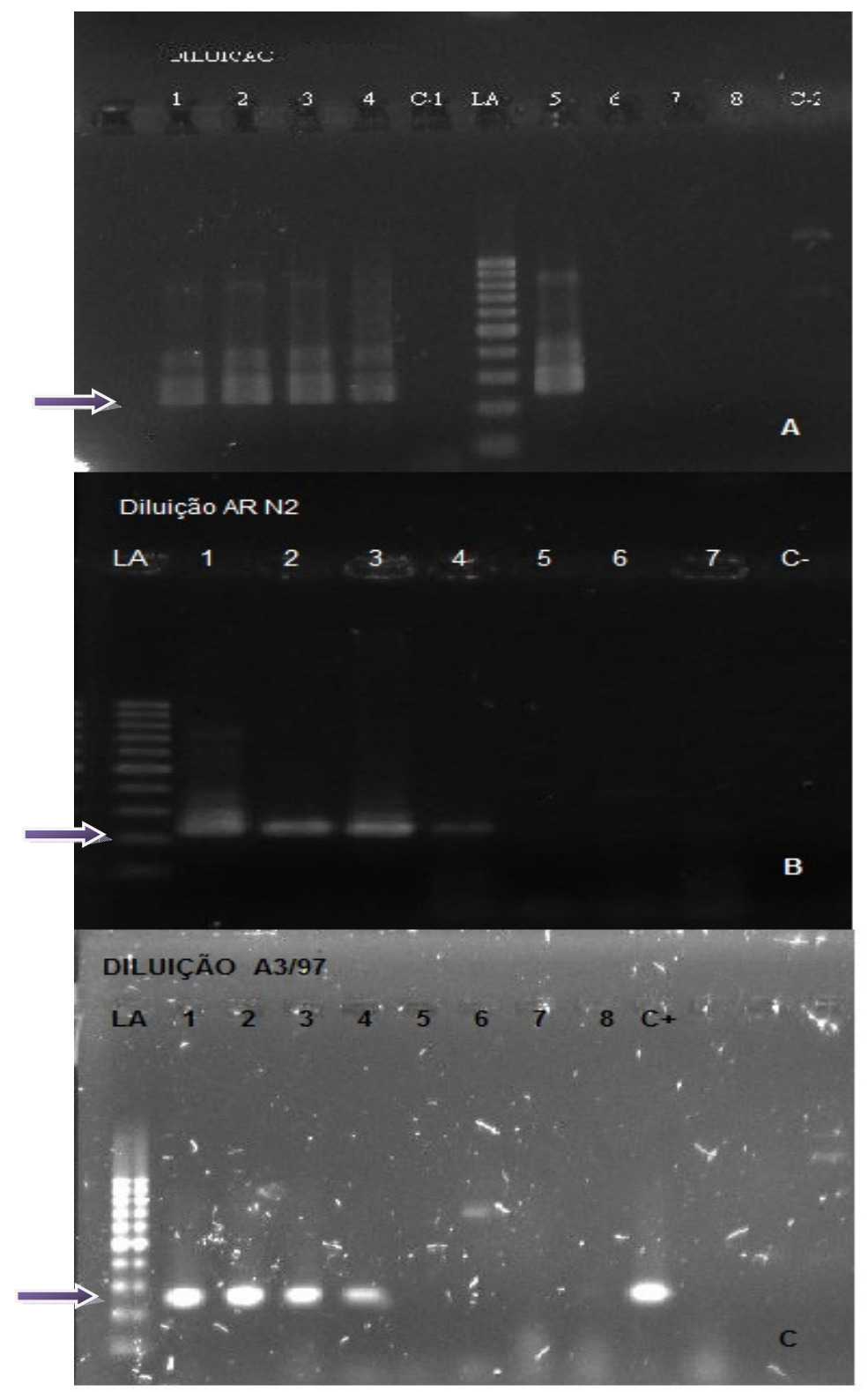

Figura 6- Géis dos produtos amplificados pela nested-PCR das diluições virais. Considerando- se positivos os fragmentos de aproximadamente $263 \mathrm{pb}$. (A): AR N1 (ARG1) positivo até a 5o diluição, (B): AR N2 e (C) A3/97 positivos até a 4ํ diluição; "C+": controle positivo; "C-“: controle negativo 


\subsection{OBSERVAÇÃO DOS ANIMAIS INOCULADOS}

Após as 12 primeiras horas de inoculação, tanto os camundongos inoculados quanto os camundongos controles apresentaram pêlos arrepiados e apatia. Nos três dias seguintes de observação não foram constatados quaisquer sinais clínicos nos animais inoculados e/ou controles.

A necropsia foi realizada ao $4^{\circ}$ dia pós-inoculação. Não foi observada nenhuma alteração macroscópica nos órgãos dos animais inoculados e/ou controle.

\subsection{PESQUISA DO EHV-1 NOS ÓRGÃOS DOS CAMUNDONGOS EXPERIMENTALMENTE INOCULADOS.}

Os órgãos dos animais utilizados como controles das inoculações foram negativos para EHV-1 tanto para os órgãos congelados quanto para os órgãos incluídos em parafina (Quadro12).

Com relação os fragmentos congelados, em todos os camundongos inoculados foi possível a recuperação do DNA viral do pulmão 100\% (12/12), enquanto que, para o SNC a recuperação do DNA viral não foi possível em apenas um dos camundongos inoculados com A3/97, 91\% (11/12) (figura 7). 


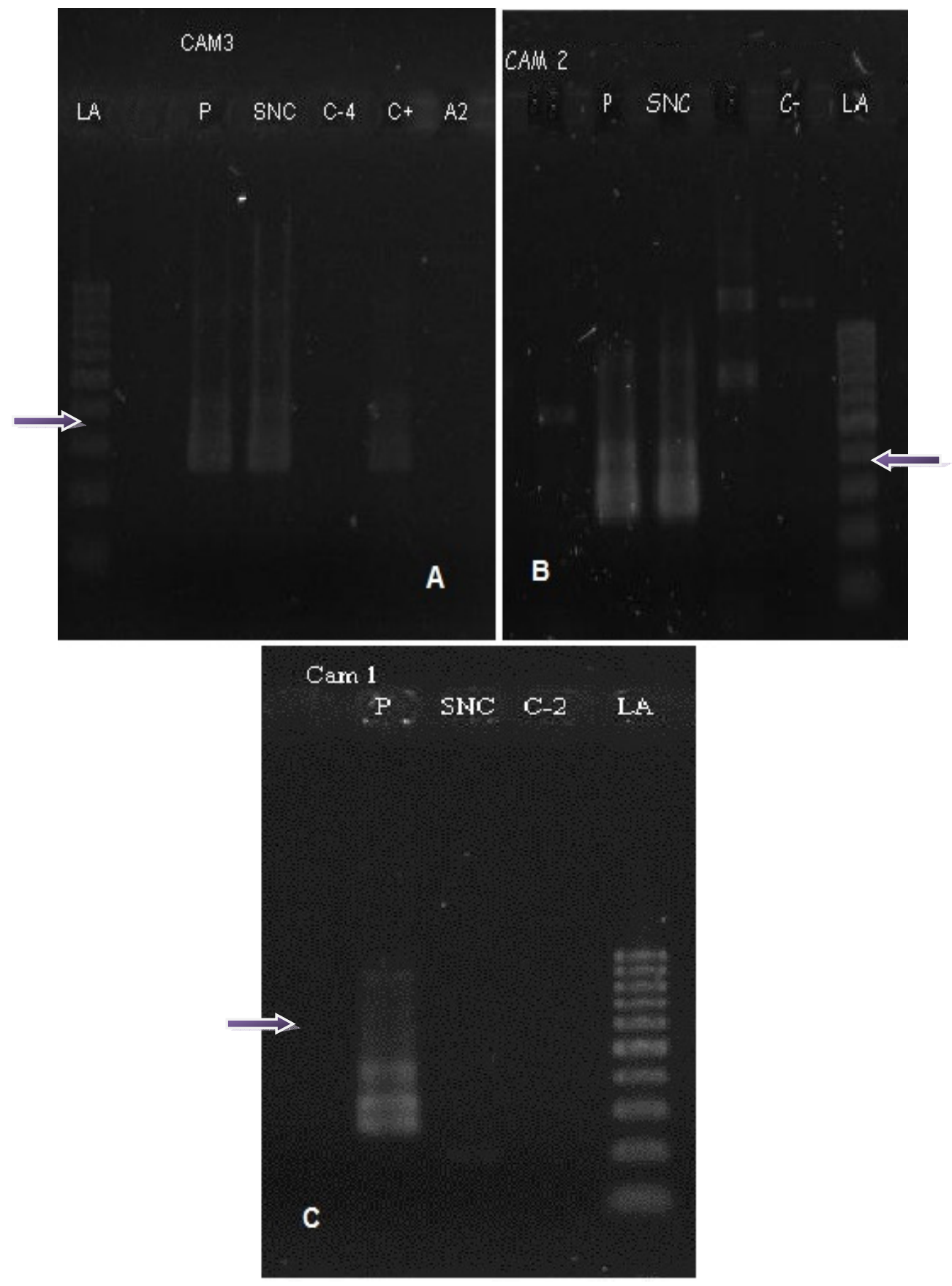

Figura 7- llustração da positividade dos órgãos congelados dos camundongos inoculados com EHV1. (A) camundongo inoculado com o isolado $A R N 1$; (B) camundongo inoculado com 0 isolado AR N2. (C) camundongo inoculado com A3/97. Considerando positivos os fragmentos com tamanho de 263pb. "P": pulmão, "SNC": sistema nervoso central, "C-": controle negativo, "C+": controle positivo; "A": controle negativo da nested-PCR, "LA": padrão de pares de base (lader). 
O protocolo de extração para órgãos incluídos em parafina foi realizado com fragmentos de $20 \mu \mathrm{m}$ e de $36 \mu \mathrm{m}$ (conforme descrito no item 4.3.4). Quando realizado

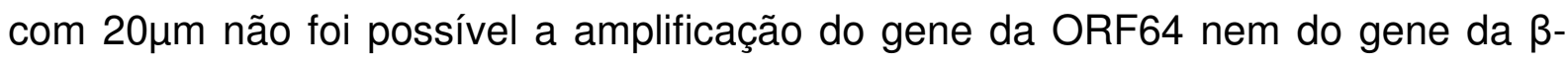
actina, quando realizado com $36 \mu \mathrm{m}$ a amplificação foi positiva para os dois genes (ORF64 e $\beta$-actina).

Os resultados da extração e amplificação dos órgãos incluídos em parafina apresentados são apenas das extrações realizadas com fragmentos de $36 \mu \mathrm{m}$.

A amplificação do DNA viral, recuperado dos fragmentos de pulmão incluídos em parafina, foi possível em todos os camundongos inoculados 100\% (12/12) (figura 8). À recuperação do DNA viral do SNC foi possível em três camundongos inoculados com AR N1 (3/4), um camundongo inoculado com AR N2 (1/4) e um camundongo inoculado com A3/97 (1/4) no total $41 \%$ (5/12) dos fragmentos foram positivos para a pesquisa do EHV-1 quadro 12. 


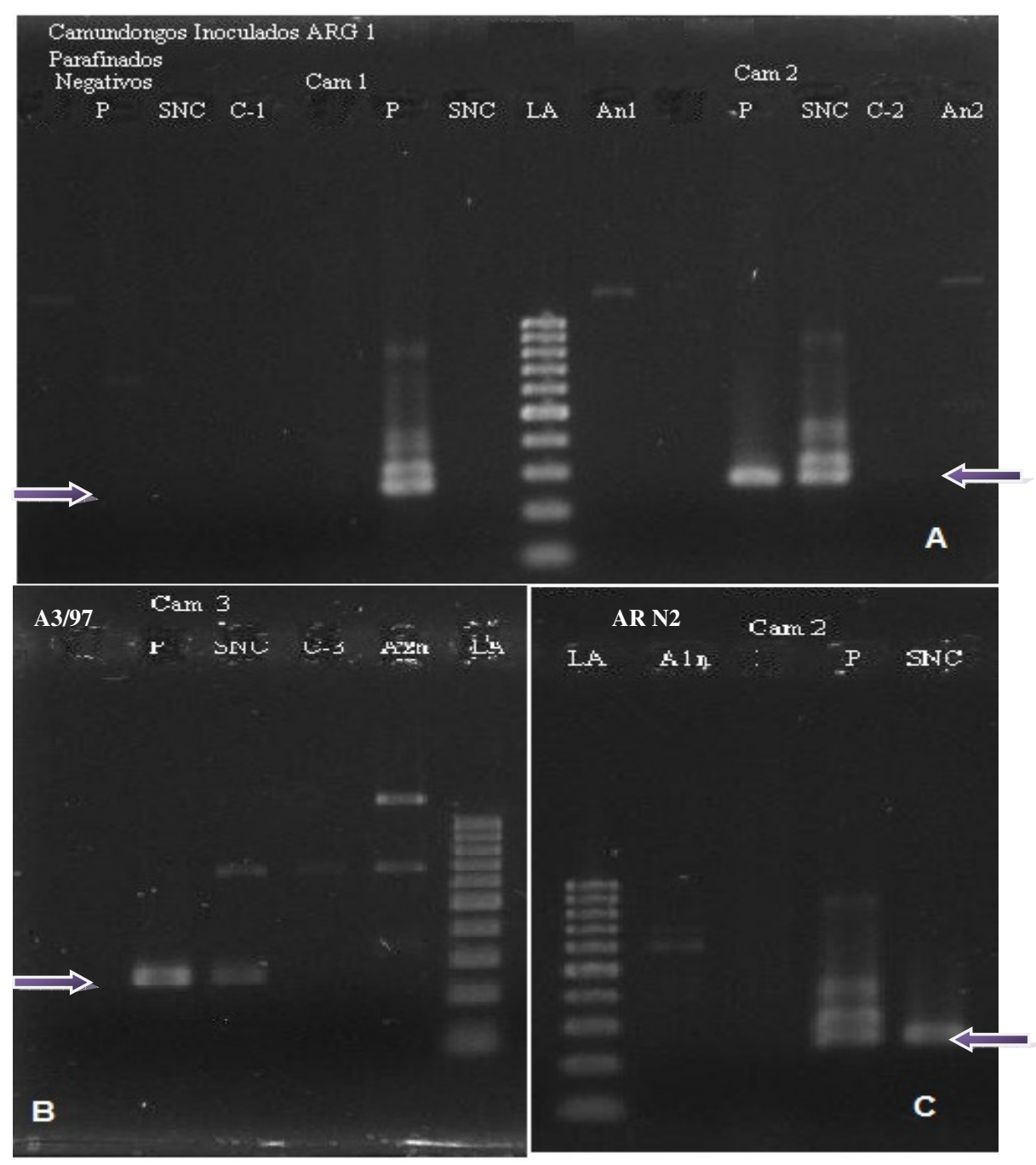

Figura 8- llustração da positividade dos órgãos incluídos em parafina dos camundongos inoculados com EHV-1. (A) camundongos inoculados com AR N1; (B) camundongo inoculado com o isolado A3/97; (C) camundongo inoculado com o isolado AR N2. Considerando positivos os fragmentos de 263pb. "P": pulmão, "SNC": sistema nervoso central, "C-": controle negativo, "C+": controle positivo; "A": controle negativo da nested-PCR, "LA":padrão de pares de base (lader). 


\begin{tabular}{|c|c|c|c|c|c|c|c|c|c|}
\hline & & \multicolumn{3}{|c|}{ CONGELADOS } & \multicolumn{3}{|c|}{ PARAFINADOS } & \multicolumn{2}{|c|}{ HISTOTÉCNICA } \\
\hline ISOLADO & ANIMAIS & PULMÃO & SNC & $\beta$-Actina & PULMÃO & SNC & $\beta$-Actina & PULMÃO & SNC \\
\hline \multirow{5}{*}{ AR N1 } & 1 & + & + & + & + & - & + & B & SAP \\
\hline & 2 & + & + & + & + & + & + & A & SAP \\
\hline & 3 & + & + & + & + & + & + & $\mathrm{C}$ & SAP \\
\hline & 4 & + & + & + & + & + & + & A & SAP \\
\hline & Neg. & - & - & + & - & - & + & SAP & SAP \\
\hline ISOLADO & ANIMAIS & PULMÃO & SNC & $\beta$-Actina & PULMÃO & SNC & $\beta$-Actina & PULMÃO & SNC \\
\hline \multirow{5}{*}{ AR N2 } & 1 & + & + & + & + & - & + & A & SAP \\
\hline & 2 & + & + & + & + & + & + & C & SAP \\
\hline & 3 & + & + & + & + & - & + & A & SAP \\
\hline & 4 & + & + & + & + & - & + & & SAP \\
\hline & Neg. & - & - & + & - & - & + & SAP & SAP \\
\hline ISOLADO & ANIMAIS & PULMÃO & SNC & $\beta$-Actina & PULMÃO & SNC & $\beta$-Actina & PULMÃO & SNC \\
\hline \multirow{5}{*}{ A3/97 } & 1 & + & - & + & + & - & + & $\mathrm{D}$ & SAP \\
\hline & 2 & + & + & + & + & - & + & $\mathrm{E}$ & SAP \\
\hline & 3 & + & + & + & + & + & + & $E$ & $\mathrm{~F}$ \\
\hline & 4 & + & + & + & + & - & + & D & $\mathrm{F}$ \\
\hline & Neg. & - & - & + & - & - & + & SAP & SAP \\
\hline
\end{tabular}

Órgãos positivos para gene da $\beta$ - actina.

Fragmentos com resultados concordantes nos órgãos congelados e incluídos em parafina.

Fragmentos com resultados discordantes entre amostras congeladas e incluídas em parafina.

Infiltrado inflamatório mononuclear focal

B- Infiltrado inflamatório mononuclear moderado e congestão

Infiltrado inflamatório mononuclear difuso e congestão

D- Infiltrado inflamatório mononuclear difuso enfisema

E- Infiltrado inflamatório intersticial mononuclear e infiltardo inflamatório polimorfonuclear bronquiolar F- Infiltrado inflamatório mononuclear

SAP- Sem alteração patológica.

Quadro 12: Reusltado detalhado dos órgãos dos camundongos inoculados, congelados e incluídos em parafina, positivos para pesquisa do EHV-1 e para $\beta$ actina. 


\subsection{CONTROLE DE $\beta$-ACTINA}

Os órgãos congelados e incluídos em parafina que foram negativos para o EHV-1 foram submetidos a PCR para o gene da beta-actina, resultando em positividade para todos os fragmentos dos órgãos testados (Figura 9).

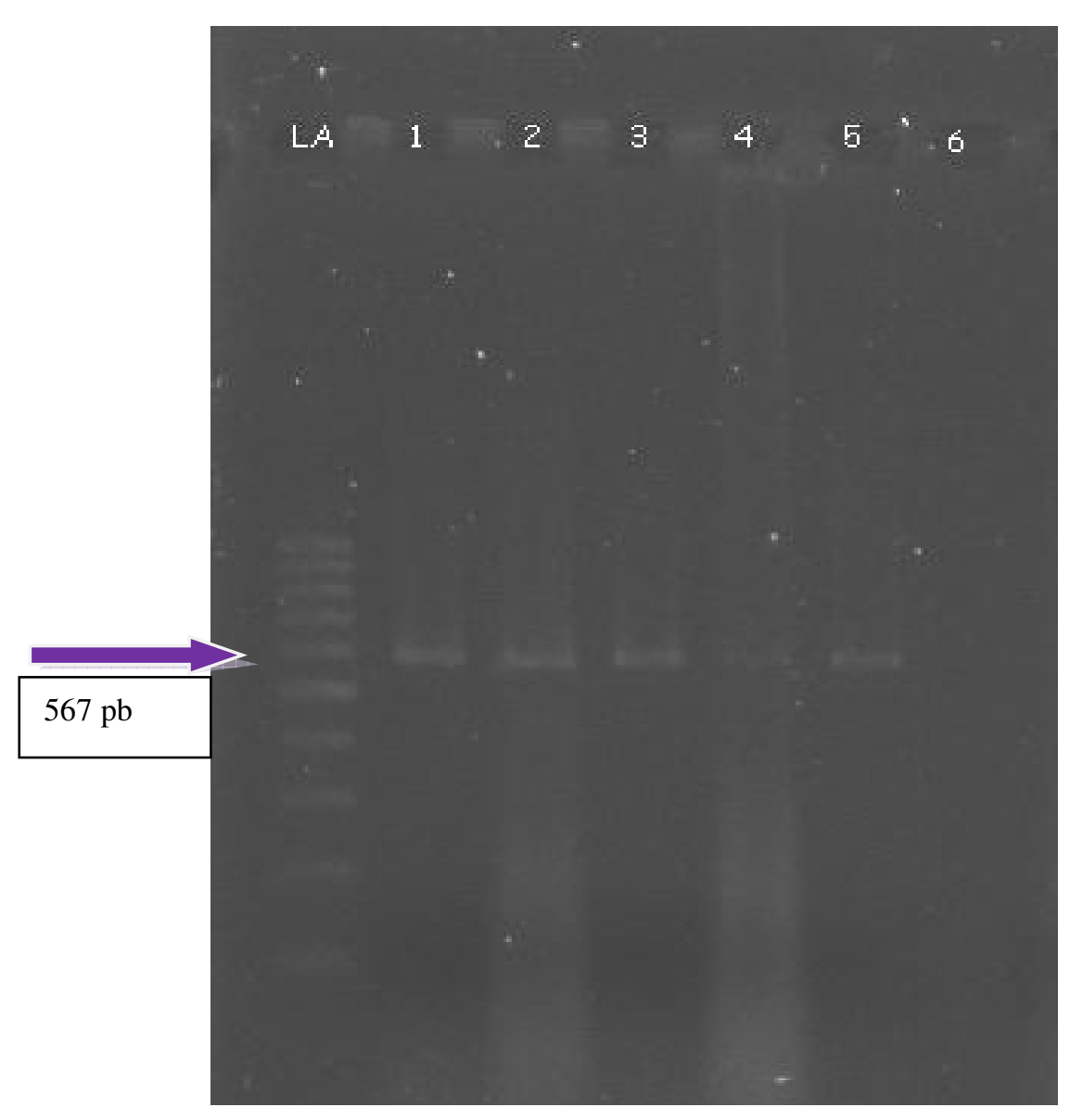

Figura 9- Foto ilustrativa das amostras positivas para o gene da beta-actina dos órgãos incluidos em parafina dos camundongos do grupo de inoculados com AR N2 E A3/97, considerando positivas as amostras com fragmento com aproximadamente de 567pb. As colunas 1-2 são do camundongo inoculado com AR N2, colunas 3- 5 do camundongos inoculados com A3/97 e coluna 6 controle negativo. 


\subsection{ASSOCIAÇÃO ENTRE PRESENÇA DO DNA VIRAL E LESÕES HISTOPATOLOGICAS.}

Os órgãos dos camundongos utilizados como controle negativo da inoculação não apresentaram alterações histopatológicas (figura 10). Os camundongos inoculados com os três diferentes isolados de EHV-1 apresentaram lesões no pulmão e SNC quadro 12.

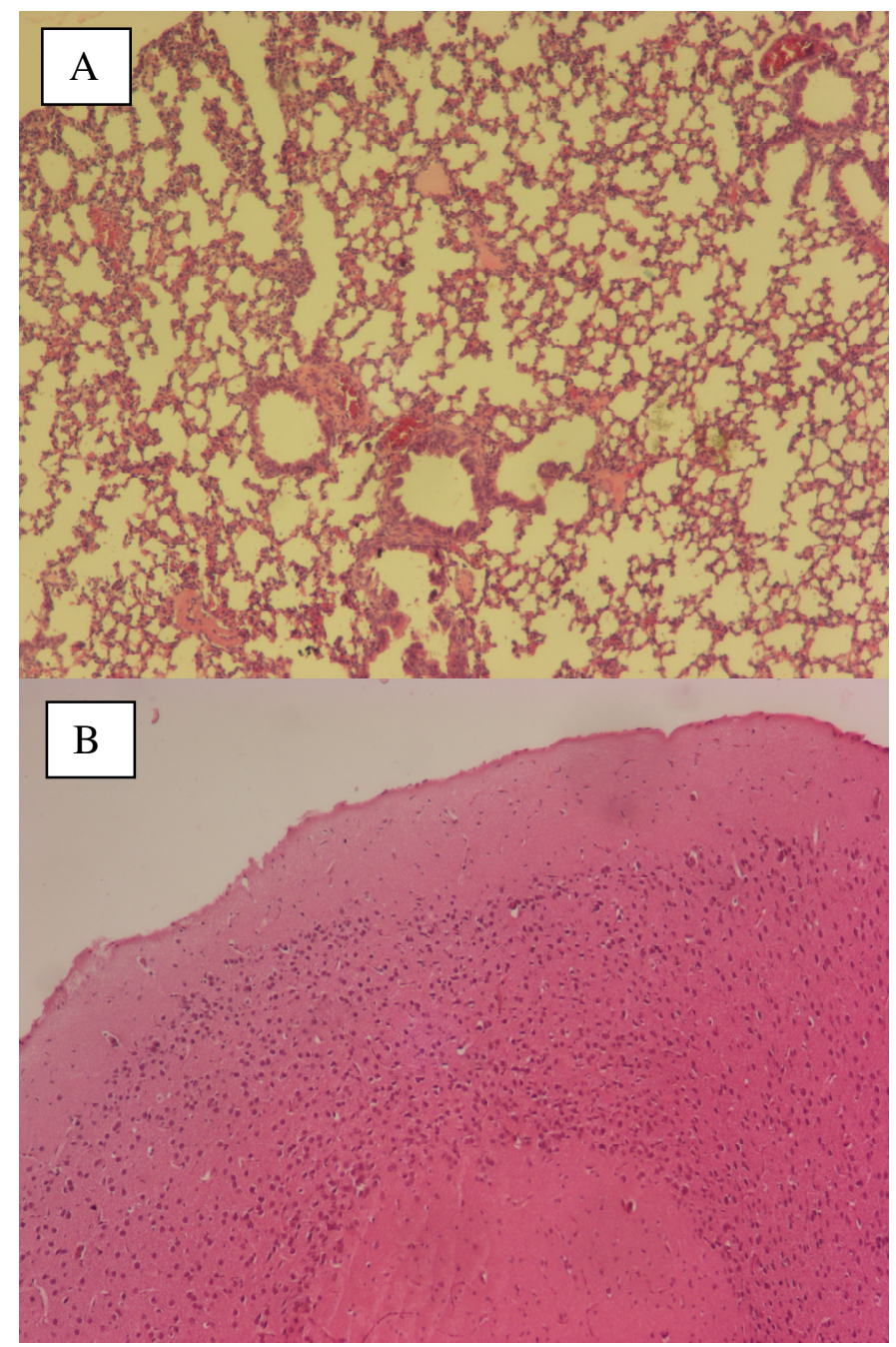

Figura 10: llustração do pulmão (a) e do SNC (b) mostrando morfologia normal dos órgãos (aumento de100x). 
Todos os camundongos inoculados com os três diferentes isolados apresentaram lesão no pulmão (Quadro 12). As lesões encontradas variam de infiltrado inflamatório mononuclear discreto a moderado, com ou sem congestão e com ou sem enfisema, que estão representadas nas figuras $11,12,13$ e 14 . Nos pulmões dos camundongos que apresentaram lesões histopatológicas, não foi observada inclusão intranuclear.

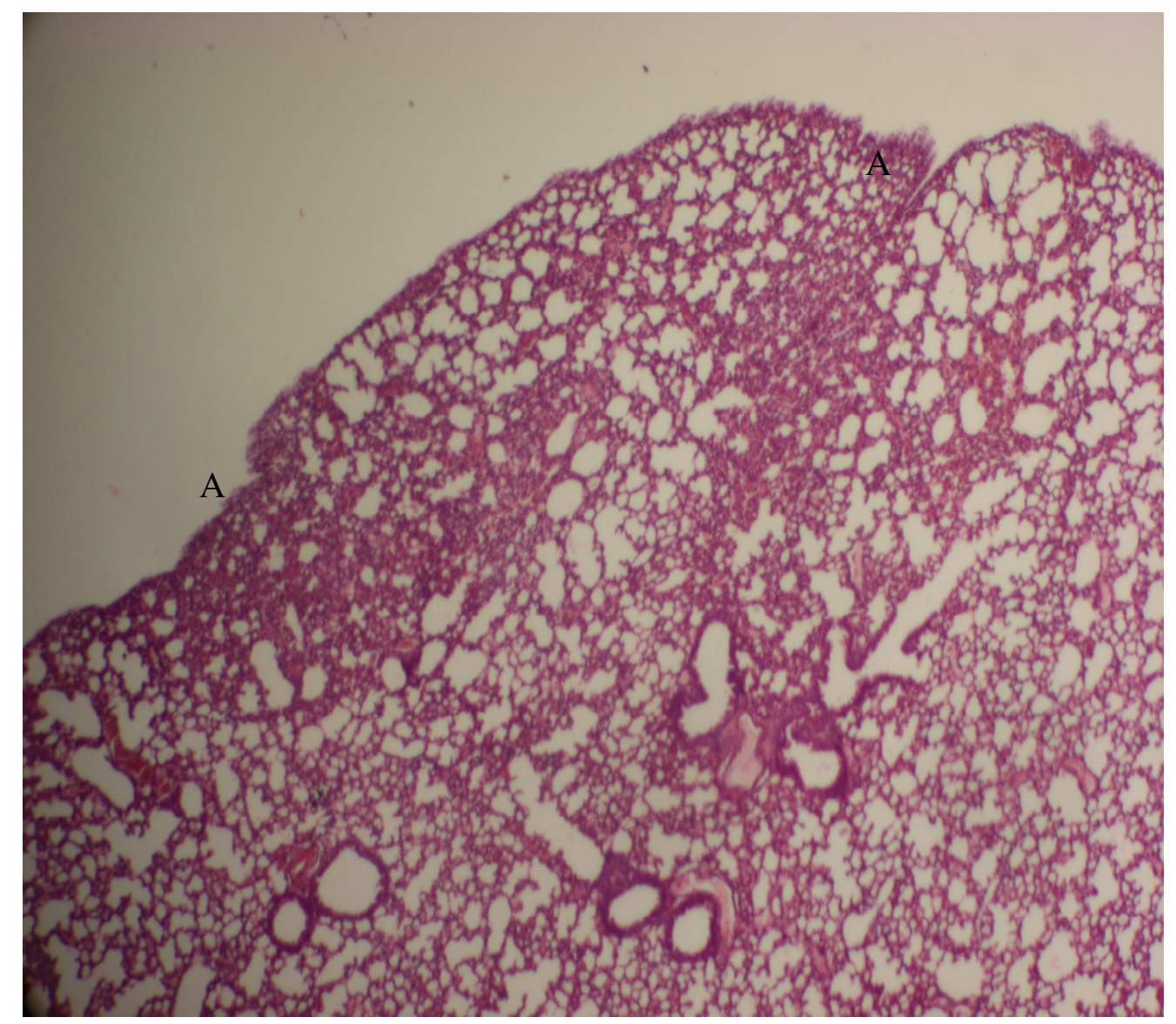

Figura 11: llustração da lesão pulmonar classificada como infiltrado inflamatório mononuclear focal com congestão (A) (aumento 40x). 


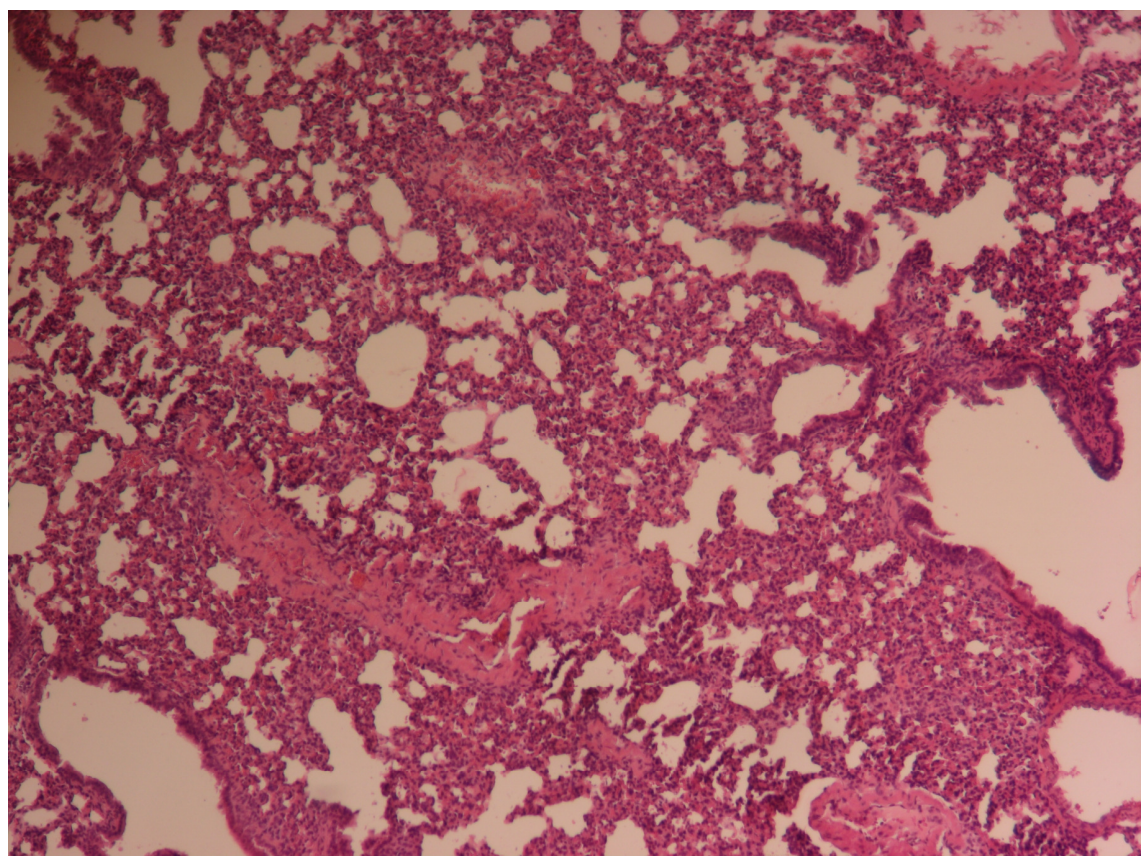

Figura 12: Ilustração da lesão pulmonar classificada como infiltrado inflamatório mononuclear intersticial moderado difuso (aumento de 100x).

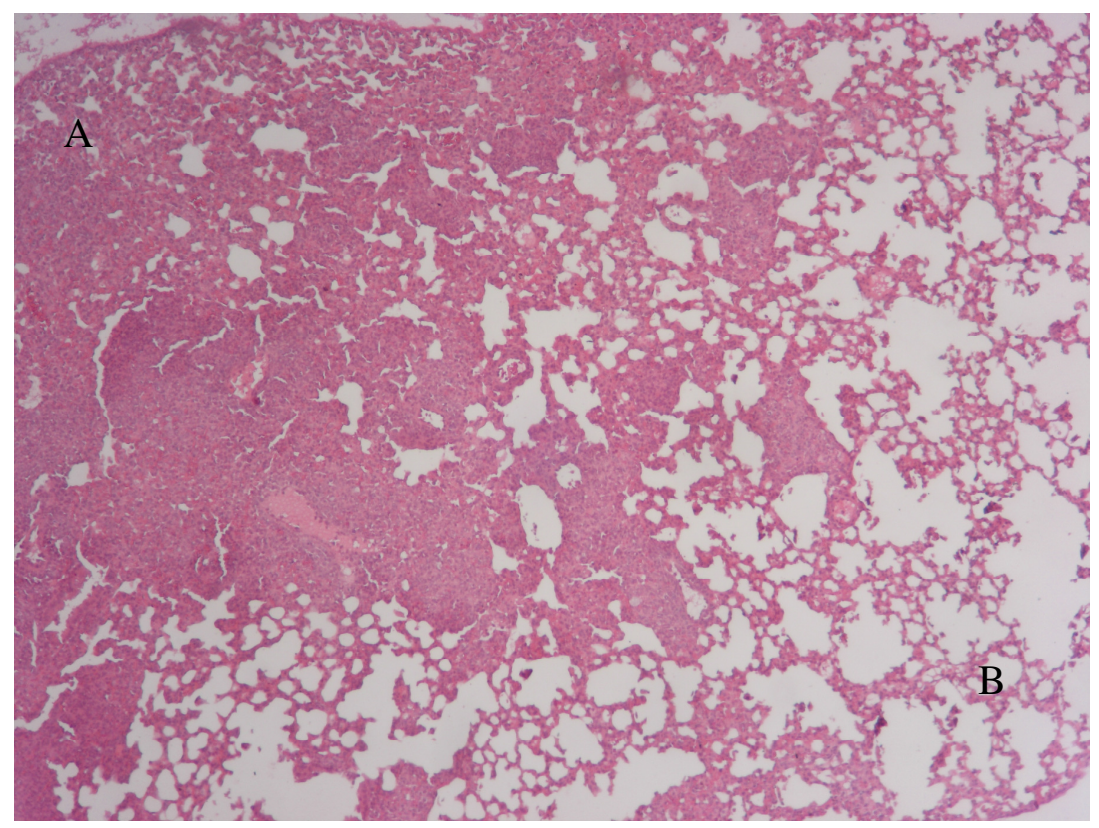

Figura 13: Ilustração da lesão pulmonar classificada como infiltrado inflamatório mononuclear intersticial severo e difuso (A) com enfisema alveolar (B) (aumento 40x). 


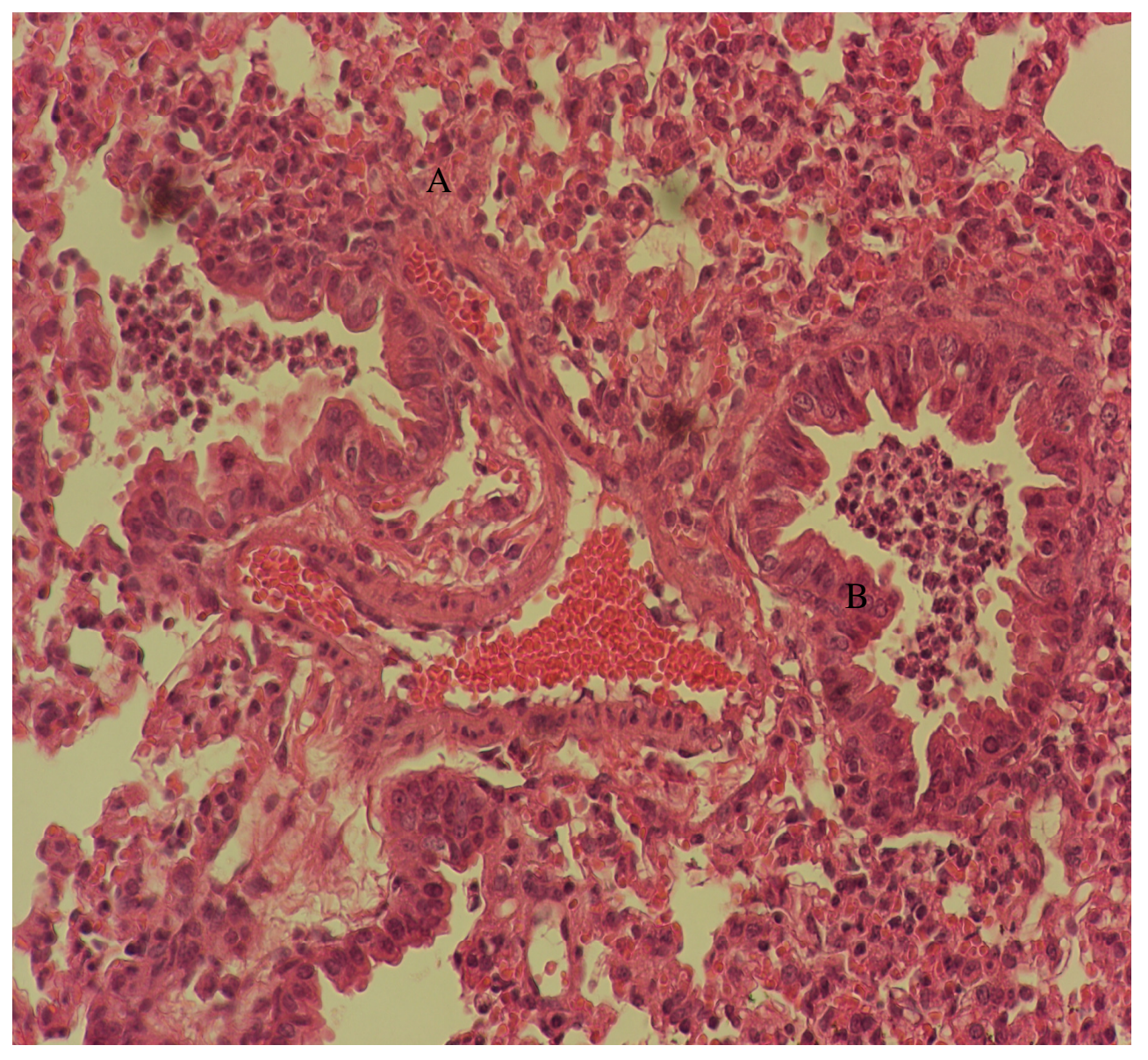

Figura 14: Ilustração da lesão pulmonar classificada como infiltrado inflamatório mononuclear intersticial moderado (A) e neutrófilos no lúmen dos bronquíolos (B) (aumento 400x).

Os camundongos isolados com AR N1 e AR N2 não apresentaram lesões no sistema nervoso central (SNC), foi observado infiltrado inflamatório mononuclear em apenas dois dos animais inoculados com o isolado brasileiro A3/97. (Figura15). 


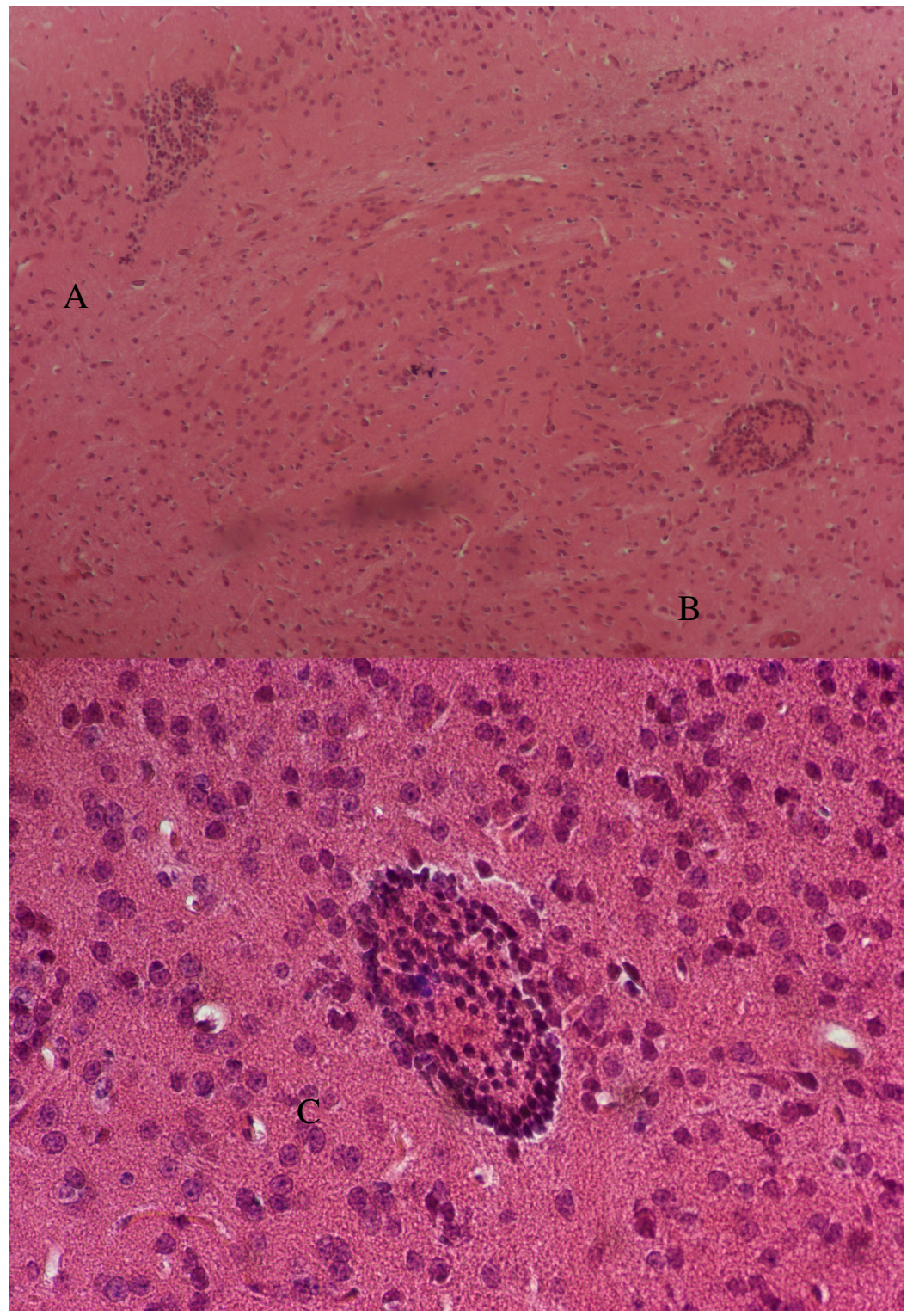

Figura 15: llustração do SNC destacando o foco de infiltrado inflamatório mononuclear (a) e manguito perivascular mononuclear (b) no neurópilo (Aumento de 100x). Em (c) manguito perivascular mononuclear no neurópilo (aumento de 400x). 


\subsection{PESQUISA DO EHV-1 NAS AMOSTRAS CLÍNICAS}

Para comprovar a aplicabilidade das técnicas de extração e amplificação do DNA viral provenientes de órgãos incluídos em parafina, foram processados cinco casos clínicos decorrentes de aborto equino, dois casos de 2007, dois casos de 2008 e um caso de 2010 (Quadro 13).

Esses órgãos haviam sido previamente testados pelo Laboratório de Raiva e Encefalites do Instituto Biológico. A pesquisa do EHV-1 foi realizada através das técnicas de isolamento viral em cultivo celular e PCR para a região da glicoproteina B. Os casos clínicos analisados em 2007 e 2008 foram negativos e o caso de 2010 foi positivo.

\begin{tabular}{|c|c|c|c|c|}
\multirow{2}{*}{ AMOSTRAS } & \multirow{2}{*}{ ANO } & \multicolumn{2}{|c|}{$\begin{array}{c}\text { RESULTADO INICIAL } \\
\text { (INSTITUTO BIOLOGICO) }\end{array}$} & $\begin{array}{c}\text { RESULTADO PCR } \\
\text { PADRONIZADA } \\
\text { (NESTE ESTUDO) }\end{array}$ \\
\hline $\mathbf{1}$ & 2007 & PCR $^{*}$ & ISOLAMENTO** & + \\
\hline $\mathbf{2}$ & 2007 & - & - & + \\
\hline $\mathbf{3}$ & 2008 & - & - & + \\
\hline $\mathbf{4}$ & 2008 & - & - & + \\
\hline $\mathbf{5}$ & 2010 & + & + & + \\
\hline
\end{tabular}

*: amostras frescas analisadas com a PCR descrita por Kirisawa.

Quadro 13: Amostras clínicas utilizadas para comprovar a aplicabilidade da PCR padronizada para extração de EHV-1 de órgãos incluídos em parafina.

As amostras clínicas incluídas em parafina testadas pela PCR padronizada foram positiva para o EHV-1 em pelo menos um, dos fragmentos de órgão de cada 
caso clínico testado (Figura 16). Os fragmentos de órgão que foram negativos para o EHV-1 foram testados para o gene de beta-actina, resultando em positividade para todos os órgãos.

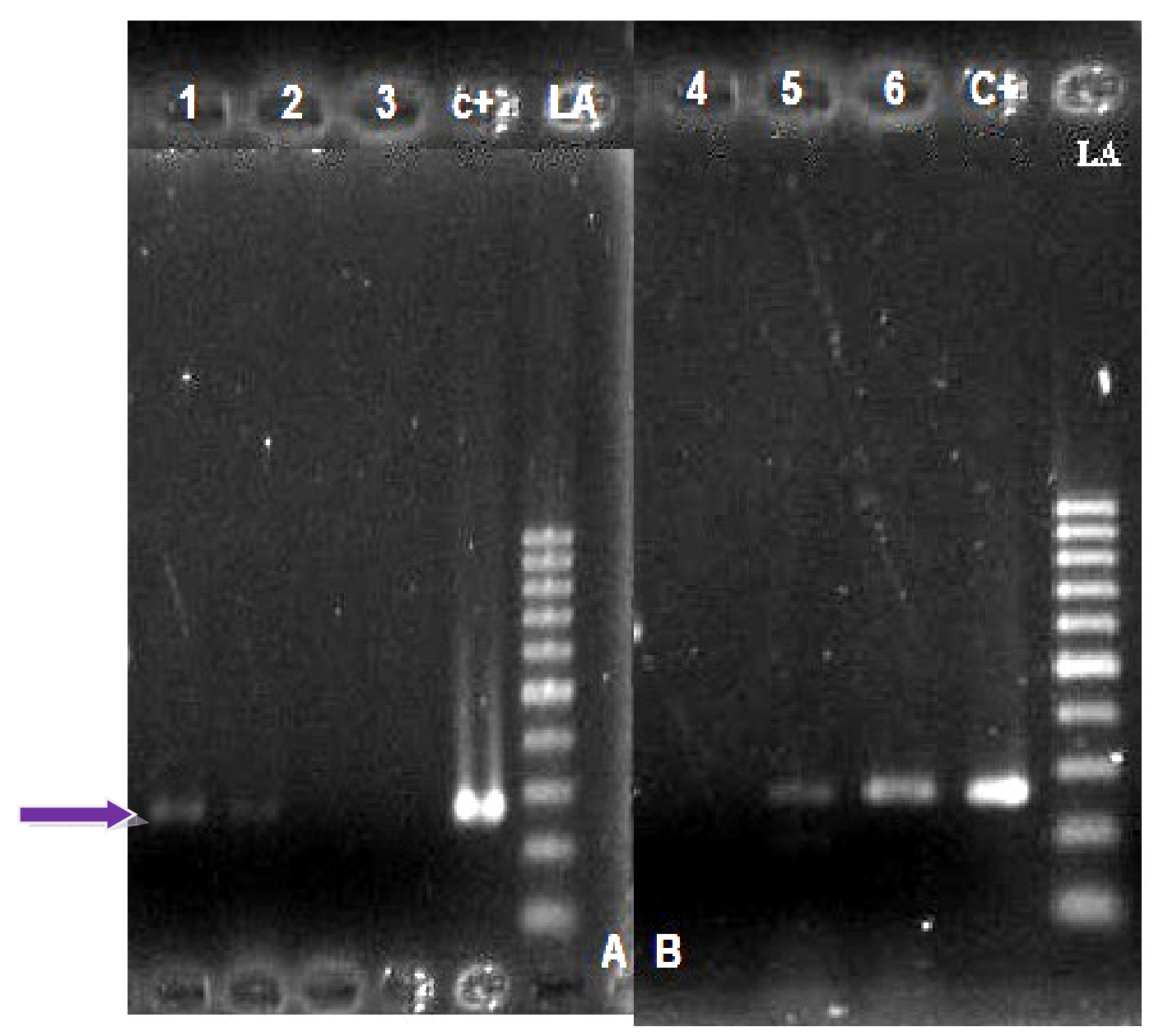

Figura 16- Gel ilustrativo dos fragmentos amplificados das amostras clínicas testadas para a presença de EHV-1. (A): linhas 1 e 2 amostras de 2007 e 2008, 3 controle negativo; C+ controle positivo; (B): linhas 4 controle negativo, 5 e 6 amostras de 2010, C+ controle positivo. 
Qualquer pessoa pode ter conhecimento, Mas a arte de pensar é o dom mais escasso da natureza. Frederico 11 da Prússia 


\section{DISCUSSÃO}

Os resultados da sensibilidade analítica demonstraram que a nested-PCR utilizada neste estudo é capaz de detectar o DNA viral alvo em uma diluição que

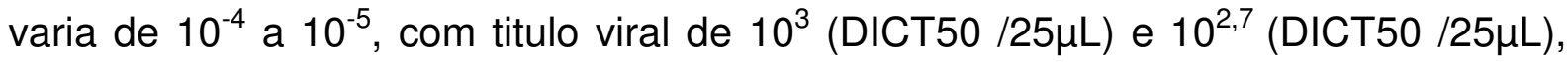
respectivamente. Padronizando a PCR para pesquisa do vírus da língua azul (VENDITTI, 2009) obteve positividade até a diluição $10^{-4}$ com titulo de $10^{4,7}$ (DICT50/ml), que se assemelha aos resultados obtidos neste trabalho.

Como modelo experimental de laboratório foi utilizado o camundongo por mimetizar a infecção primária no trato respiratório que ocorre no hospedeiro natural. AWAN; CHONG; FIELD, (1990) descartaram o uso de hamsters para inoculação do EHV, devido à replicação primaria ocorrer no fígado, diferindo da infecção natural em equídeos.

Os camundongos foram inoculados com um volume de $25 \mu \mathrm{l}$, via IN. A variação no volume inoculado $(25 \mu l)$ pode causar: a) perda de parte do inóculo (volume menor que $25 \mu \mathrm{l}$ ), porque alguns dos animais apresentaram episódios de "espirros" logo após a aspiração do inóculo; b) a morte dos animais por asfixia (volume maior que $25 \mu \mathrm{l}$ ). Mori et al,(2011) trabalhando com inoculação experimental em camundongos, utilizaram $25 \mu$ l do inóculo para a experimentação.

A apatia aparente nas primeiras 12 horas pós-inoculação parece estar associada à sedação, pois tanto os animais controles quanto os inoculados com EHV-1 apresentaram comportamento normal após esse período, não sendo associada à infecção pelo EHV-1. 
A padronização do tempo da fixação e do $\mathrm{pH}$ da formalina são importantes para diminuir a degradação do DNA do agente e do hospedeiro presente nos fragmentos de tecido. O tempo de estocagem dos órgãos incluídos em parafina não interfere na degradação do DNA, podendo realizar a extração desse material em tempo indeterminado (AN; FLEMING, 1991; GHAZVINI et al., 1996; KRAFFT et al., 1997; COOMBS; GOUGH; PRIMROSE, 1999).

${ }^{* *} A$ preparação para extração das amostras incluídas em parafina foi realizada com duas lavagens sequênciais de xilol, para remoção da parafina dos fragmentos. Apesar de usar solvente orgânico a técnica é eficiente na remoção da parafina para recuperação do DNA de EHV-1 (RIMSTAD; EVENSEN, 1993; O'KEEFE et al., 1994).

A extração dos órgãos congelados foi realizada em tampão de lise com proteinase $\mathrm{K}(\mathrm{PK})$, incubados por quatro horas a $55^{\circ} \mathrm{C}$. A extração do material incluído em parafina foi realizada em tampão de lise com PK incubado overnigt a $55^{\circ} \mathrm{C}$, resultando na recuperação de DNA de boa qualidade para a amplificação da ORF64 e $\beta$-actina. De acordo com An, Fleming (1991) e Isola (1994) a incubação em tampão de lise, dos fragmentos incluídos em parafina, favorece a reversão da ligação entre as proteínas nucleares e o DNA, aumentando a eficiência da extração quando incubados por mais de seis horas.

Para a utilização do mesmo protocolo de nested-PCR tanto para as amostras congeladas quanto para as amostras incluídas em parafina, a quantidade dos fragmentos dos órgãos incluídos em parafina foi aumentada de $20 \mu \mathrm{m}$ para $36 \mu \mathrm{m}$, otimizando a PCR.

$\mathrm{Na}$ literatura compulsada a quantidade de fragmentos dos órgãos incluídos em parafina usada para a extração de DNA é variável $(5-48 \mu \mathrm{m})$ resultando em 
amplificação positiva, mas os trabalhos não visam o uso do mesmo protocolo de amplificação para material congelado e incluído em parafina.. Rimstad; Evensen, (1993) pesquisando EHV-1 de material incluído em parafina utilizaram fragmentos de $5 \mu \mathrm{m}$; Krafft et al,(1997) pesquisando RNA de diversos agentes (Morbillivirus, vírus da cinomose, $\beta$-actina dentre outros) utilizaram de quatro a oito fragmentos de $6 \mu \mathrm{m}$ e Chan et al, (2001) pesquisando HPV e o controle interno de betaglobina humana, utilizaram três fragmentos de $5 \mu \mathrm{m}$.

$\mathrm{Na}$ extração e amplificação do DNA viral dos pulmões dos camundongos inoculados com os três diferentes isolados, todos os fragmentos congelados e incluídos em parafina foram positivos para a presença do EHV-1 100\% (12/12) (Quadro 12).

A positividade do pulmão na PCR é atribuída à via de inoculação (IN) que mimetiza a infecção natural que ocorre pelo contato direto (secreções nasais) entre animais e pelo desenvolvimento primário do vírus acorrer na mucosa do trato respiratório (REED; TORIBIO 2004; PATEL; HELDENS, 2005; GALOSI et al., 2006).

$\mathrm{Na}$ avaliação histopatológica dos pulmões as inclusões intranucleares não foram observadas. WALKER et al. (1998) e GALOSI et al. (2006) relatam que a observação da inclusão intranuclear pode ser entre $1^{\circ}$ e $7^{\circ}$ dias pós inoculação (PI), contudo, é mais frequente a observação das inclusões no primeiro dia PI. A partir do $2^{2}$ dia PI é, comumente observado apenas o infiltrado de células mononucleares.

Nos fragmentos do SNC armazenados a $-20^{\circ} \mathrm{C}$ a extração e amplificação do DNA viral foram possível em $100 \%$ (8/8) dos camundongos inoculados com os isolados AR N1 e AR N2, e em 75\% (3/4) dos camundongos inoculados com A3/97, total de $91 \%$ (11/12) dos fragmentos positivos para a presença do EHV-1 (Quadro 12). 
Os fragmentos do SNC incluídos em parafina apresentaram diminuição na recuperação do DNA viral, sendo três positivos para AR N1 75\% (3/4), um positivo para AR N2 25\% (1/4) e um positivo para A3/97 25\% (1/4), totalizando 41\% (5/12) dos fragmentos positivos para a presença do EHV-1 (Quadro 12).

A positividade no SNC pode ser atribuída a viremia, pois os virions são carreados pelos monócitos para diferentes órgãos do animal, ou pela disseminação neural através do bulbo olfatório atingindo principalmente região cortical e hipocampo (REED; TORIBIO, 2004; GOSZTONYI; BORCHES; LUDWIG, 2009; MORI et al., 2011).

Possíveis causas para que os fragmentos de SNC, inclusos em parafina, serem negativos na PCR seriam: a distribuição não homogênea do vírus pela amostra e uma menor replicação do vírus no SNC.

${ }^{* *}$ Quanto às lesões histopatológicas, o SNC apresentou infiltrado inflamatório mononuclear em dois dos camundongos inoculados com o isolado brasileiro (A3/97). Esses achados discordam dos relatos de Mori et al. (2011) onde os camundongos inoculados com esse mesmo isolado não apresentaram lesões histopatológicas em SNC.

O controle de $\beta$-actina empregado para verificar a eficiência da extração, integridade do DNA e a ausência de inibidores na PCR cumpriu seu papel visto que todos os fragmentos de amostras testados foram positivos (AN; FLEMING, 1991; ROSENSTRAUS et al., 1998; CHAN et al., 2001).

Com relação à possível fragmentação do DNA extraído dos fragmentos de órgãos fixados em formalina e incluídos em parafina, os resultados indicam que o método empregado teve bom desempenho, uma vez que os primers para $\beta$-actina 
amplificam um fragmento de 567pb e os de ORF64 amplificam um fragmento de 410pb.

Com a utilização de um protocolo semelhante as descrito neste trabalho, CHAN et al. (2001) ao utilizarem o gene humano de betaglobina como controle para extração de DNA de material parafinado obtiveram apenas 50\% (10/10) das amostras positivas com tamanho do fragmento de 509 pb. Rimstad; Evensen, (1993) pesquisando EHV-1 relatam que fragmentos menores que 450pb são amplificados com maior eficiência, enquanto que em fragmentos maiores dificilmente são amplificados. No presente estudo a amplificação de fragmentos de DNA de até $567 \mathrm{pb}$ foi eficiente. 
Escrever é fácil. você começa com uma maíuscula e termina com um ponto final. No meio, coloca idéias. Pablu Neruda 


\section{CONCLUSÕES}

- A PCR padronizada apresentou uma sensibilidade analítica para deteç̧ão do EHV-1 que varia de $10^{-1}$ a $10^{-2}$ DICT50/25 $\mathrm{LL}$.

- Em amostras de pulmão de animais experimentalmente inoculados, a PCR padronizada foi capaz de detectar o EHV-1 independentemente das amostras terem sido submetidas ao congelamento ou a inclusão em parafina.

- Em amostras de SNC dos animais experimentalmente inoculados, a PCR padronizada foi capaz de detectar o EHV-1 em 5/11 dos fragmentos do SNC incluídos em parafina.

- Nas amostras clínicas incluídas em parafina, a PCR padronizada foi eficiente na amplificação do DNA viral, sendo positiva em pelo menos um dos fragmentos testados para cada caso clínico avaliado e, provavelmente, apresenta uma sensibilidade diagnóstica mais elevada que os métodos utilizados previamente para o diagnóstico do EHV-1 na coleção de amostras testadas. Sugerindo que o mesmo possa ser usado em eventuais pesquisas retrospectivas do EHV-1 em material de arquivo de histopatologia. 
Nenhum livro é tão ruím que não possa ser usado ser usado sob algum aspecto Plinio, o velho 


\section{REFERÊNCIAS}

ALLEN, G.P. Respiratory infections by equine herpesvirus types 1 and 4 . In: LEKEUX, P. Equine Respiratory disease. New York: International Veterinary Information Service (IVIS), Feb, 2002. Disponível em: <http://www.ivis.org >. Acesso em: jul. 2010.

ALLEN, G. P.; TURTINEN, L. W. Assessment of the Ase Sequence Homology Between the two Subtypes of Equine Herpesvirus 1. Journal of Virology, Washington, p. 249-255, Oct., 1982.

ALLEN, G. P.; BRYANS, J. T. Epizootiologia molecular, patogênese e profilaxia das infecções equinas por herpesvírus -1. In: PANDEY R. Microbiologia Veterinária. Perspectivas Clínicas e Moleculares. Roca, 1994. p. 77-139.

ALLEN, T. C. Hematoxilina y eosina. In: PROPHET, E. B. et al. (Ed.). Métodos Histotecnológicos. Washington: Registro de Patologia de los Estados Unidos de América, cap. 9, p. 55-60, 1995.

AN, S. F.; FLEMING, K. A. Removal of inhibitor(s) of the polymerase chain reaction from formalin fixed, paraffin wax embedded tissues. Journal of Clinical Pathology, Londres, v. 44, p. 924-927, 1991.

ASANO, K. M.; NASSAR, S. F. C.; CUNHA, E. M. S.; VILLALOBOS, E. M. C.; MIYASHIRO, S.; MORI, E.; FERNANDES, W. R.; LARA, M. C. C. S. H. Pesquisa do herpesvírus equino tipo 1 e do vírus da arterite equina em amostras de fetos abortados. In: SIMPÓSIO DE INICIAÇÃO CIENTÍFICA DA USP, 15, 2007.

AWAN, A. R.; BAXI, M.; FIELD, H. J. EHV-1 Induced abortion in mice and its relationship to stage of gestation. Research in Veterinary Science, Oxford, v. 59, p. 139-145, 1995. 
AWAN, A. R.; CHONG, Y. C.; FIEL, H. J. The patogenesis os equine herpesvirus type 1 in the mouse: a new model for studying host responses to the infection. Journal of General Virology, Londres, v. 71, p. 1131-1140, 1990.

BAREA, J. A.; PARDINI, M. I. M. C.; GUSHIKEN, T. Extração de DNA de materiais de arquivo e fontes escassas para utilização em reação de polimerase em cadeia (PCR). Revista Brasileira de Hematologia e Hemoterapia. São Paulo, v. 26, n. 4, p. 274-281, 2004.

BARTELS, T.; STEINBACH, F.; HAHN, G.; LUDWIG, H.; BORCHERS, K. In situ study on the pathogenis and immune reaction of equine herpesvirus type 1 (EHV-1) infection in mice. Immunology, Oxford, v. 93, p. 329-334, 1998.

BLUNDEN, A. S.; SMITH, K. C.; BINNS, M. M.; ZHANG, L.; GOWER, S. M.; MUMFORD, J. A. Replication of equid herpesvirus 4 in endotelial cells and sinovitis in a foals. Journal of Comparative Pathology, Liverpool, v.112, p. 133-140, 1995.

BORCHES, K.; WOLFINGER, U.; SCHELLENBACH, A.; LAWREZ, B.; GLITZ, F.; LUDWIG, H. Equine herpesvirus type 1 and trigeminal ganglia of naturally infected horses: detection of dna and latency associated transcripts. In: INTERNATIONAL CONFERENCE ON EQUINE INFECTIOUS DISEASES, 8, 1999. Proceedings... Newmarket: R\&W Publications, 1999, p. 147-152.

BRASIL. MINISTÉRIO DA AGRICULTURA, PECUÁRIA E ABASTECIMENTO. Anexo à Instrução Normativa no040, de 30 de Julho de 2008. Relação de produtos e Insumos Agropecuários sob Anuência do MAPA. Disponível em: <MAPAhttp://www.agricultura.gov.br/arq_editor/file/Aniamal//mporta\%C3\%A7\%C3\% A3o/ANEXO\%20\%20INSTRUCAO\%20NORMATIVA\%20N\%20040\%2031_03_11.pd $\mathrm{f}>$. Acesso em: 27/05/2011

BRASIL. MINISTÉRIO DA AGRICULTURA, PECUÁRIA E ABASTECIMENTO.

Equídeos. Disponível em: <http://www.agricultura.gov.br/portal/page/portal//nternetMAPA/pagina-inicial/animal/especies/equideos>. Acesso em: 27/05/2011.

BRASIL. MINISTÉRIO DA AGRICULTURA, PECUÁRIA E ABASTECIMENTO. Estatísticas de Comércio Exterior. Disponível em: <http://www.agricultura.gov.br/internacional/indicadores-e-estatisticas>. Acesso em: 27/05/2011. 
BRASIL. MINISTÉRIO DA AGRICULTURA, PECUÁRIA E ABASTECIMENTO. Manual de Legislação: Programas Nacionais de Saúde Animal no Brasil. Brasília, 2009. Disponível em:

<http://www.agricultura.gov.br/arq_editor/file/Aniamal/Manual\%20de\%20Legisla\%C3 $\%$ A7\%C3\%A30\%20-\%20Sa\%C3\%BAde\%20Animal\%20-\%20low.pdf>. Acesso em: 27/05/2011.

BRASIL. MINISTÉRIO DO DESENVOLVIMENTO, INDÚSTRIA E COMÉRCIO EXTERIOR. Estatística: Balança Comercial das Carnes Brasileiras, 2011.

Disponível em:

$<$ http://www.mdic.gov.br/sitio/interna/interna.php?area=2\&menu=885\&refr=855>. Acesso em: 27/05/2011.

BROWN, J. A.; MAPES, S.; BALL, B. A.; HODDER, A. D. J.; LIU, I. K. M.; PUSTERLA,N. Prevalence of equine herpesvirus-1 infection among thoroubreds residing on a farm on wich the virus was endemic. Journal of American Veterinary Medical Association, Chicago, v. 231, n. 4, 2007.

CHAN, P. K. S.; CHAN, D. P. C.; TO, K. F.; YU, M. Y.; CHEUNG, J. L. K.; CHENG, A. F. Evaluation of extration methods from parafim wax embedded tissue for pcr amplification of human and viral DNA. Journal of Clinical Pathology, Londres, v. 54, p. 401-403, 2001.

COOMBS, N. J.; GOUGH, A. C.; PRIMROSE, J. N. Opitmisation of DNA and RNA extraction from archival formalin-fixed tissue. Nucleic Acids Reserch, Oxford, v. 27, n. 16, 1999.

CORRÊA, W. M.; NILSON, M. R. Observações preliminares sobre o aborto equino a vírus, no brasil. Arquivos do Instituto Biológico, São Paulo, v. 31, n. 3, p. 13-15, 1964.

CUNHA, E. M. S.; FERRARI, C. I. L; LARA, M. C. C. S. H.; SILVA, L. H. Q. Presença de anticorpos contra o herpesvirus equino 1 (hve-1) em equinos do noroeste do estado de São Paulo. Arquivos do Instituto Biológico, São Paulo, v. 69, p. 1-5, 2002. 
DEL FAVA, C.; LARA, M. C. C. S. H.; VILLALOBOS, E. M. C.; NASSAR, A. F. C.; CABRAL, A. D.; TORELLI, C. S.; CUNHA, M. S.; CUNHA, E. M. S. Ocorrência de leucoencefalomalacia (LEMA) em equídeos no estado de São Paulo, Brasil: achados anatomopatológicos. Brazilian Journal Veterinary Research Animal Science, São Paulo, v. 47, n. 6, p. 488-494, 2010.

DIEL, D. G.; ALMEIDA, S. R.; WEIBLEN, R.; FRANDOLOSO, R.; ANZILIERO, D.; KREUTZ, L. C.; GROFF, F. H. S.; FLORES, E. F. Prevalência de anticorpos contra o vírus da influenza da arterite viral e herpesvírus em equinos do estado do Rio Grande do Sul, Brasil. Ciência Rural, Santa Maria, v. 36, p. 1467-1673, 2006.

FERNANDES, J. V.; MEISSNER, R. V.; FERNANDES, T. A. M.; ROCHA, L. R. M.; CABRAL, M. C.; VILLA, L. L. Comparação de três protocolos de extração de dna a partir de tecido fixado em formal e incluído em parafina. Jornal Brasileiro Patologia e Medicina Laboratorial, Rio de Janeiro, v. 40, n. 3, p. 141-146, 2004.

FLUVAC® Innovator EHV 4/1. Responsável técnico Dr. Christopher Roger White. Campinas: FORT DODGE Saœde Animal Ltda, 1995. Bula de remédio[Online]. Disponível em: <http://www.fortdodge.com.br/divisoes/equinos/equinos_exibicao_bula.php?Produto $=38 \&$ TipoProduto=7>. Acesso em: 17 jun. 2011.

GALOSI, C. M.; BARBEITO, C. G.; MARTIN OCAMPOS, G. P.; MARTINEZ, J. P.; AYALA, M. A.; CORVA, S. G.; FUENTEALBA, N. A.; GIMENO, E. J. An argentine equine herpesvirus strain with special restriction patterns protect mice challenge with a pathogenic strain. Journal of Veterinary Medicine B, Berlin, v. 53, p. 412-417, 2006.

GALOSI, C. M.; BARBEITO, C. G.; VILA ROZA, M. V.; CID de la PAZ, V.; AYALA, M. A.; CORVA, S. G.; ETCHEVERRIGARAY, M. E.; GIMENO, E. J. Argentine strain of equine herpesvirus 1 isolate from an aborted foetus shows low virulence in mouse respiratory and abortion models. Veterinary Microbiology, Amsterdan, v. 103, p. 112, 2004.

GALOSI, C. M.; VILA ROZA, M. V.; OLIVA, G. A.; PECORARO, M. R.; ECHEVERRIA, M. G.; CORVA, S.; ETCHEVERRIGARAY, M. E. A Polimerase chain reaction for detection of equine herpesvirus-1 in routine diagnostic submissions of tissue from aborted fetuses. Journal of Veterinary Medicine B, Berlin, v. 48, p. 341346, 2001. 
GAZVINI, S.; CHAR, D. H.; KROLL, S.; WALDMAN, F. M.; PINKEL, D. Comparative genomic hybridization analysis of archival formalin-fixed paraffin-embedded uveal melanomas. Cancer Genetics and Cytogenetics, New York, v. 90, p. 95-101, 1996.

GILKERSON, J. R.; LOVE, D. N.; WALLEY, J. M. Epidemiology of equine herpesvirus abortion: searching for clues to the future. Australian Veterinary Journal, Carlton, v. 76, 1998.

GILKERSON, J. R.; WALLEY, J. M.; DRUMMER, H. E.; STUDDERT, M. J.; LOVE, D. N. Epidemiology of EHV-1 and EHV-4 in the mare and foal populations on a hunter valley stud farm: are mares the source of EHV-1 for unweaned foals.

Veterinary Microbiology, Amsterdan, v. 68, p. 27-34, 1999.

GOSZTONYI, G.; BORCHES, K.; LUDWIG, H. Pathogenesis of equine herpesvirus-1 infection in the mouse model. Acta Pathologica, Microbiologica et Immunologica Scandinavica, Copenhagen, v. 117, p. 10-21, 2009.

HERPESHORSE - Vacina contra Rinopneumonite Equina (vírus 1 e 4). Campinas: Laboratórios Vencofarma do Brasil Ltda, 2008. Bula de remédio[Online]. $<$ http://www.vencofarma.com.br/bra/produtos_det.php?cod=75>. Acesso em: 17 jun. 2011.

INACIO, A. SP: Exportador de carne de cavalo de olho na China. Valor Econômico, São Paulo, 12 jan. 2010. Disponível em:

<http://www.canaldoprodutor.com.br/comunicacao/noticias/sp-exportador-de-carnede-cavalo-de-olho-na-china>. Acesso em: 27/05/2011

INSTITUTO BRASILEIRO DE GEOGERAFIA E ESTATÍSTICA. Produção Pecuária Municipal (PPM), 2009. Disponível em:

<http://www.ibge.gov.br/home/estatistica/economia/ppm/2009/default_pdf.shtm>. Acesso em: 27/05/2011.

INSTITUTO BRASILEIRO DE GEOGRAFIA E ESTATÍSTICA. Sistema IBGE de Recuperação Automática (SIDRA). Banco de Dados Agregados:

Efetivo/Rebanhos. Disponível em:

$<$ http://www.sidra.ibge.gov.br/bda/pecua/default.asp?t=2\&z=t\&o=24\&u1 =1\&u3=1\&u4 $=1 \& u 5=1 \& u 6=1 \& u 7=1 \& u 2=3>$. 
INTERNATIONAL COMMITTEE ON TAXONOMY OF VIRUSES. Virus Taxonomy: 2009 Release. Disponível em:

$<$ http://www. ictvonline.org/virusTaxonomy.asp?version=2009>. Acesso em:

30/05/2011.

ISOLA, J.; DEVRIES, S.; CHU, L.; GHAZVINI, S.; WALDMAN, F. Analysis of changes in DNA sequence copy number by comparative genomic hybridization in archival paraffin-embedded tumor samples. American Journal of Pathology, Philadelphia, v. 145, n. 6, 1994.

JAMBHEKAR, N. A.; KULKARNI, S. P.; MADUR, B. P.; AGARWAL, S.; RAJAN, M. G. R. Application of the polymerase chain reactionon formalin-fixed, paraffinembedded tissue in the recognition of tuberculous osteomyelitis. Journal of Bone and Joint Surgery, London, v. 88-B, n. 8, 2006.

KRAFFT, A. E.; DUNCAN, B. W.; BIJWAARD, K. E.; TAUBENBERGER, J. K.; $\mathrm{LICHY}, \mathrm{J}$. H. Optimization of the isolation and amplification of rna from formalin fixed, paraffin-embedded tissue: the armed forces institute of pathology experience and literature review. Molecular Diagnosis, Naperville, v. 2, n. 3, p. 217-228, 1997.

LARA, M. C. C. S. H.; CUNHA, E. M. S.; NASSAR, A. F. C.; GREGORY, L.; BIRGEL, E. H.; FERNANDES, W. R. Ocorrência do herpesvírus equino 1 (EHV-1) em cavalos criados no estado de São Paulo, Brasil. ARS Veterinária, Jaboticabal, v. 19, n. 3, p. 254-259, 2003.

LARA, M. C. C. S. H.; CUNHA, E. M. S.; VILLALOBOS, E. M. C.; NASSAR, A. F. C.; ASANO, K. M.; FERNANDES, W. R.; RICHTZENHAIN, L. J.; BRANDÃO, P. E.;

MORI, E. First isolation of equine herpesvirus type 1 from a horse with neurological disease in Brazil. Arquivos do Instituto Biológico, São Paulo, v. 75, n. 2, p. 221224, 2008.

LÉON, A.; FORTIER, G.; FORTIER, C.; FREYMUTH, F.; TAPPREST, J.;

LECLECRCQ, R.; PRONOST, S. Detection of equine herpesvirus in aborted fetuses by consensus PCR. Veterinary Microbiology, Amsterdan, v. 126, p. 20-29, 2008.

LIMA, R. A. S. Mudanças recentes no mercado de carne de cavalo. 30 Jul. 2010. Disponível em: <http://www.slideshare.net/620arruda/artigo-equina-30-jul-ago2010>. Acesso em: 27/05/2011. 
LUNN, D. P.; DAVIS-POYNTER, N.; FLAMINIO, M. J. B. F.; HOROHOV, D. W.; OSTERRIEDER, K.; PUSTERLA, N.; TOWNSEND, H. G. G. Equine herpesvirus-1 consensus statement. Journal of Veterinary Internal Medicine, v. 23, p. 450-461, 2009.

MAEDA, K.; MIZUKOSHI, F.; HAMANO, M.; KAI, K.; IWATA, H.; KONDO, T.; MATSUMURA, T. Development of na Equine Herpesvirus Type 4-Specific EnzymeLinked Immunosorbent Assay Using a B-Cell Epitopes as na Antigen. Journal of Clinical Microbiology, Washington, v. 42, n. 3, p. 1095-1098, Mar. 2004.

MARENZONI, M. L.; PASSAMONTI, F.; CAPPELLI, K.; VERONESI, F.; CAPOMACCIO, S.; SUPPLIZI, A. V.; VALENTE, C.; AUTORINO, G.; COLETTI, M. Clinical, Serological and Molecular Investigations of EHV-1 and EHV-4 in 15 Unweaned Thoroughbred Foals. Veterinary Record, Londres, v. 162, p. 337-341, 2008.

MESQUITA, R. A.; ANZAI, E. K.; OLIVEIRA, R. N.; NUNES, F. D. Avaliação de três métodos de extração de dna de material parafinado para amplificação de DNA genômico pela técnica da PCR. Pesquisa Odontológica Brasileira, São Paulo, v. 15, p. 314-319, 2001.

MOREIRA, N.; KRUGER, E. R.; WARTH, J. F. G.; BIESDORF, S. M.; GOULARTE, M. M. M.; WEISS, R. R. Aspectos etiológicos e epidemiológicos do aborto equino. Archives of Veterinary Sciences, Curitiba, v. 3, n. 1, p. 25-30, 1998.

MOREIRA, N.; WEISS, R. R.; KRUGER, E. R. Frequência de anticorpos neutralizantes contra o herpesvirus equino tipo 1. Scientia Agraria, Curitiba, v. 1, n. 1-2, p. 9-14, 2000.

MORI, C. M. C.; MORI, E.; FAVARO, L. L.; SANTOS, C. R.; LARA, M. C. C. S. H.; VILLALOBOS, E. C.; CUNHA, E. M. S.; BRANDÃO, P. E.; RICHTZENHAIN, L. J.; MAIORKA, P. C. Equid herpesvirus type-1 exhibits neurotropism and neurovirulence in a mouse model. Journal of comparative pathology, Edinburgh, v. 144, p. 1-9, 2011. 
NAGARAJAN, M. M.; SIMARD, C. Detection of horses infected naturally with equine infectious anemia virus by nested polymerase chain reaction. Journal of Virological Methods, Amsterdan, v. 94, p. 97-109, 2001.

NILSON, M. R.; CORRÊA, W. M. Isolamentos do vírus do aborto equino no estado de São Paulo. Arquivos do Instituo Biológico, São Paulo, v. 33, n. 2, p. 23-25, 1966.

O'KEEFE, J. S.; JULIAN, A.; MORIARTY, K.; MURRAY, A.; WILKS, C. R. A comparison of the polymerase chain reaction with standard laboratory methods for the detection of EHV-1 and EHV-4 in archival tissue sample. New Zeland Veterinary Journal. v. 42, p. 93-96, 1994.

PAGAMJAV, O.; SAKATA, T.; MATSUMURA, T.; YAMAGUCHI, T.; FUKUSHI, H. Natural recombinant between equine herpesvirus 1 and 4 in the ICP4 gene. Microbiology and Immunology, Tokyo, v. 49, n. 2, p. 167-179, 2005.

PATEL, J. R.; HELDENS, J. Equine herpesvirus1 (EHV-1) and 4 (EHV-4) epidemiology, disease and immunoprophylaxis: a brief review. Veterinary Journal, Londres, v. 170, p. 14-23, 2005.

PIMENTEL, L. A.; OLIVEIRA, D. M.; GALIZA, G. J. N.; REGO, R. O.; DANTAS, A. F. M.; RIET-CORREA, F. Doenças do sistema nervoso central de equídeos no semiarido. Pesquuisa Veterinária Brasileira. v. 29, n. 7, 2009.

PROPHET, E. B. Procesamiento de tejidos: deshidratación, aclaramiento y infiltración. In: et al. (Ed.). Métodos Histotecnológicos. Washington: Registro de Patologia de los Estados Unidos de América, 1995. Cap. 5, p. 31-34.

PUSTERLA, N.; WILSON, W. D.; SAMANTHA, M.; FINNO, C.; ISBELL, D.; ARTHUR, R. M.; FERRARO, G. L. Characterization of viral loads, strain and state of equine herpesvirus-1 using real-time PCR in horses following natural exposure at a racetrack in California. The Veterinary Journal, Londres, 2007. 
REED, S. M.; TORIBIO, R. E. Equine herpesvirus 1 and 4.

Veterinary Clinics of North America, Equine Practice, Philadelphia, v. 20, p. 631642, 2004.

RIMSTAD, E.; EVENSEN, O. The identification of equid herpesvirus1 in paraffinembedded tissue from aborted fetuses by polymerase chain reaction and immunohistochemisry. Journal of Veterinary Diagnostic Investigation, Columbia, v. 5 , p. 174-183, 1993.

ROGERS, B. B.; ALPERT, L. C.; HINE, E. A. S.; BUFFONE, G. J. Analysis of DNA in fresh and fixed tissue by the polymerase chain reaction. American Journal of Pathology, New York, v. 136, n. 3, p. 541-548, 1990.

ROSENSTRAUS, M.; WANG, Z.; CHANG, S.; DeBONVILLE, D.; SPADORO, J. P. An internal control for routine diagnostic pcr: design, properties, and effect on clinical performance. Journal of Clinical Microbiology. Washington, v. 36, p. 191-197, 1998.

SÁENZ, J. R.; URCUQUIINCHIMA, S. Replicación del herpesvirus equino y su asociación con la patogénesis molecular. Acta Biológica Colombiana, Bogotá, v. 11, n. 2, 2006.

SAMBROOK, J.; FRITSCH, E. F.; MANIATIS, T. Molecular cloning: a laboratory manual. 2. ed. New York: Cold Spring Harbor Laboratory Press, 1989. 2100 p.

SINCLAIR, R.; BINNS, M. M.; CHIRNSIDE, E. D.; MUMFORD, J. A. Detection of antibodies against equine herpesvirus types 1 and 4 by using recombinant protein derivad from an immunodominaant region of glicoprotein B. Journal of Clinical Microbiology, Washington, v. 31, n. 2, p. 265-271, 1993.

TEKELIOGLU, B. K.; MATSUMURA, T.; TSUJIMURA, K.; TURAN, N.; EKICI, H.; YILMAZ, $H$. Detection of equine herpesvirus type1 (EHV-1) DNA in organs of neonatal dead foals in turkey. Journal of Equine Science, Utsunomiya, v. 17, n. 1, p. 23-26, 2005. 
TELFORD, E. A. R.; WATSON, M. S.; McBRIDE, K.; DAVISON. A. The DNA sequence of equine herpesvirus-1. Virology, New York, v. 189, p. 304-316, 1992.

TELFORD, E. A. R.; WATSON, M. S.; PERRY, J.; CULLINANE, A. A.; DAVIDSON, A. J. The DNA sequence of equine herpesvirus-4. Journal of General Virology, Londres, v. 79, p. 1197-1203, 1998.

TENDENCIAS e mercado. UE aprova plano do mapa para exportação de carne de equídeos. 2010. Disponível em:

$<$ http://www.tendenciasemercado.com.br/negocios/ue-aprova-plano-do-mapa-paraexportacao-de-carne-de-equideos/>. Acesso em: 27/05/2011.

VENDITTI, L. L. R. Infecção pelo vírus da língua azul em ovinos e bovinos na região Sudeste do Brasil. 2009. Dissertação (mestrado) Instituto Biológico (São Paulo). 2009.

WALKER, C.; LOVE, D. N.; WHALLEY, J. M. Comparison of the pathogenesis of acute equine herpesvirus 1 (EHV-1) infection in the horse and the mouse model: a review. Veterinary Microbiology, Amsterdan, v. 68, p. 3-13, 1999.

WALKER, C.; PACKIARAJAH, P.; GILKERSON, J. R.; LOVE, D. N.; WALLEY, J. M. Primary and challenge infection of mice with equine herpesviruss 1, strain HSV25A. Virus Research, Amsterdan, v. 57, p. 151-162, 1998.

WANG, L.; RAIDAL, S. L.; PIZZIRANI, A.; WILCOX, G. E. Detection of respiratory herpesviruses in foals and adult horses determined by nested multiplex PCR.

Veterinary Microbiology, Amsterdan, v. 121, p. 18-28, 2007.

WEIBLEN, R.; RABUSKE, M.; REBELATTO, M. C.; NOBRE, V. M. T.;

CANABARRO, T. F. Abortion due to equine herpesvirus in southern Brazil. Brazilian Journal of Medical and Biological Research, Ribeirão Preto, v. 27, p. 1317-1320, 1994. 
YASUNAGA, S.; MAEDA, K.; MATSUMURA, T.; KONDO, T.; KAI, K. Application of a type - especific immunosorbent assay for equine herpesvírus types 1 and 4 (EHV1 And -4) to horse populations inoculated with inactivated EHV - 1 Vaccine. Journal of Veterinary Medical Science, Tóquio, v. 62, n. 7, p. 687-691, 2000. 